UNIVERSIDADE DE SÃO PAULO

Faculdade de Educação

STELA MARIS FAZIO BATTAGLIA

QUESTÕES DE LINGUAGEM NA OBRA ROBINSON CRUSOÉ:

A DIALOGIA DA PALAVRA NA VIDA SOLITÁRIA 



\section{QUESTÕES DE LINGUAGEM NA OBRA ROBINSON CRUSOÉ: A DIALOGIA DA PALAVRA NA VIDA SOLITÁRIA}

Tese apresentada à Faculdade de Educação da Universidade de São Paulo para obtenção do título de Doutor em Educação.

Área de Concentração: Linguagem e Educação Orientadora: Profa. Dra. Marina Célia Moraes Dias 
B335q Questões de linguagem na obra Robinson Crusoé: a dialogia da palavra na vida solitária / Stela Maris Fazio Battaglia; orientação Marina Célia Moraes Dias. São Paulo: s.n., 2009.

173 p. il.

Tese (Doutorado - Programa de Pós-Graduação em Educação. Área de Concentração: Linguagem e Educação) - - Faculdade de Educação da Universidade de São Paulo.

1. Bakhtin, Mikhail M. 1895-1975 2. Linguagem - Estudo e ensino 3. Literatura infanto-juvenil 4. Leitura 5. Ensino fundamental I. Dias, Marina Célia Moraes, orient. 


\section{FOLHA DE APROVAÇÃO}

Stela Maris Fazio Battaglia

QUESTÕES DE LINGUAGEM NA OBRA ROBINSON CRUSOÉ: A DIALOGIA DA PALAVRA NA VIDA SOLITÁRIA

Tese apresentada à Faculdade de Educação da Universidade de São Paulo para obtenção do título de Doutor em Educação.

Área de Concentração: Linguagem e Educação

Aprovado em:

Banca examinadora

Profa. Dra. MARINA CÉLIA MORAES DIAS

Instituição: Faculdade de Educação - USP Assinatura:

Prof. Dr.

Instituição: Assinatura:

Prof. Dr.:

Instituição: Assinatura:

Prof. Dr.:

Instituição: Assinatura:

Prof. Dr.:

Instituição: Assinatura: 

A minhas filhas "Nicia e Cindy A meus pais Joãa e Rasaura 



\section{AGRADECIMENTOS}

À Professora Marina Célia Moraes Dias, orientadora desta tese, pela confiança em meu trabalho, coragem em assumir riscos, permanente incentivo e presença.

Ao Professor Edmir Perrotti, pela ajuda, amizade e acolhimento, que serão inesquecíveis.

Ao Professor Nílson José Machado, pela capacidade de escutar, entender e auxiliar, motriz de força produtiva.

À tríade formada pelos professores Nílson, Edmir e Marina - a união de suas forças tornou possível a realização deste trabalho.

A Silvia Oberg, pelo interesse compartilhado, pela ajuda que se manifestou das mais diferentes formas, pela amizade.

A Etelvino Bechara, amigo e incentivador dos meus estudos.

Ao Professor Sergio Luiz Pereira, pelas ofertas de auxílio e orientações generosas.

À D. Marina Carrasqueira, pelas orações.

À Micaela Krumholz, por navegar comigo num mar de palavras.

$\grave{A}$ Lina Mendes, pelos momentos conjuntos de aprendizado, amizade e ajuda.

Aos inúmeros amigos aqui não nomeados - obrigada pelas palavras ditas, pelos silêncios de cumplicidade, pela força de um "estar junto."

À Marina, amiga de todas as horas.

Às minhas filhas, Nícia e Cindy, a quem é difícil expressar o significado de um agradecimento e a quem oferto este trabalho. 

À minha mãe, pela paciência em aguardar a finalização deste estudo e pela herança da curiosidade intelectual.

À Maria Aparecida Pacheco Santos, pela presença constante, incentivo e suporte prestado durante os tempos difíceis. 



\section{RESUMO}

BATTAGLIA, Stela Maris Fazio. Questões de linguagem na obra Robinson Crusoé: a dialogia da palavra na vida solitária. $173 \mathrm{f}$. Tese (Doutorado) - Faculdade de Educação, Universidade de São Paulo, São Paulo, 2009.

Esta tese apresenta um estudo sobre a criação literária de Daniel Defoe, Robinson Crusoé, escrita em 1719. Seu estatuto de obra clássica com inúmeras adaptações inserea numa cadeia discursiva de porte extraordinário, na qual o personagem revela-se um mito. O presente estudo, alicerçado no conceito de compreensão criadora de Mikhail Bakhtin, buscou uma ampliação de sentidos na análise do objeto empírico, com os seguintes objetivos: questionar um possível uso de obras clássicas como fetiches, o esvaziamento de seus sentidos e averiguar a hipótese de Robinson Crusoé ser um protótipo do homem como ser de linguagem, metalinguístico. O levantamento de tal hipótese foi possível pela concepção da dialogia da linguagem, entendida no conceito do Círculo de Bakhtin. A metodologia utilizada constou de sucessivas leituras da obra em questão, seleção de atos de linguagem expressos pelo personagem e sua categorização. A partir daí foram buscadas as representações do Outro nos enunciados de Robinson durante o período de seu total isolamento na ilha em que naufragou; a procura foi norteada pelo conceito da constituição dialógica da palavra, dado que no contexto de enunciação não havia presença real de interlocutores. Como forma de enfatizar o caráter dialógico da linguagem, realizou-se, também, uma seleção de marcas do Outro no relato autobiográfico do personagem (a obra em seu todo), algumas delas explicitamente visualizadas. As reflexões de diferentes autores acham-se presentes neste estudo: Roland Barthes, Michel de Certeau, Jeanne Marie Gagnebin, Ivonne Bordelois, Zygmunt Bauman, Dominique Maingueneau, Fernando Savater, David Olson, George Steiner. Os resultados do trabalho atestam a propriedade da hipótese formulada e demonstram a força da linguagem na vida humana, confirmando a necessidade de valorização da palavra em meio à crise cultural presente na modernidade líquida.

Palavras-chave: Dialogia da linguagem; Robinson Crusoé; Daniel Defoe; Obra clássica; Literatura infantil e juvenil. 



\begin{abstract}
BATTAGLIA, Stela Maris Fazio. Questions of language in Robinson Crusoe: the dialogics of words in a lonely life. $173 \mathrm{f}$. Thesis (Doctoral degree) - College of Education, São Paulo University, São Paulo, 2009.
\end{abstract}

The following thesis presents a study on Daniel Defoe's literary creation Robinson Crusoe, written in 1719. Its status as a literary classic that has been the subject of endless adaptations gives Robinson Crusoe an extraordinary position in the discursive chain, revealing the character as a myth. The present study, based on Mikhail Bakhtin's concept of creative understanding, sought to amplify the meanings in the analysis of its empirical object, with the following aims: to question the possible use of classic works as fetishes, to empty its meanings and to investigate the hypothesis of Robinson Crusoe being a prototype of man as a being of language, a metalinguistic being. This hypothesis was enabled by the concept of the dialogism of language, understood within the concept of Bakhtin's Circle. The methodology employed consisted of successive readings of the work, the selection of acts of language expressed by the character, and their classification into categories. From this basis, the representations of the Other in Robinson's enunciations during his period of total isolation on the island where he was shipwrecked were sought; the search was guided by the concept of the dialogic constitution of speech, since within the context of the enunciation there were no actual conversational partners present. To stress the dialogic character of language, a selection was also made of the signs of the Other in the character's autobiographical account (the work as a whole), some of which were explicitly visualized. The reflections of different authors are present in this study: Roland Barthes, Michel de Certeau, Jeanne Marie Gagnebin, Ivonne Bordelois, Zygmunt Bauman, Dominique Maingueneau, Fernando Savater, David Olson, and George Steiner. The results of this study confirm the correctness of the hypothesis proposed and demonstrate the strength of language in human life, supporting the need to value speech in the midst of the cultural crisis of liquid modernity.

Keywords: Dialogism of language; Robinson Crusoe; Daniel Defoe; Classic work; Literature for children and young people. 



\section{LISTA DE ILUSTRAÇÕES}

Figura 1 - Daniel Defoe no pelourinho............................................................. 27

Figura 2 - Quadro: A leitura (Pierre-Antoine Baudoin - 1723-1769) .................. 37

Figura 3 - E-mail - Portal do Bibliotecário............................................................ 59

Figura 4 - Página interna da Revista Robinson Crusoé (quadrinhos) - Edição

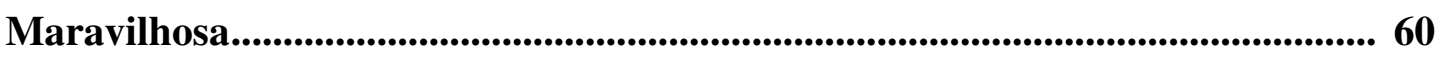

Figura 5 - Capa do livro "As aventuras de Robinson Crusoé em cordel” - Editora

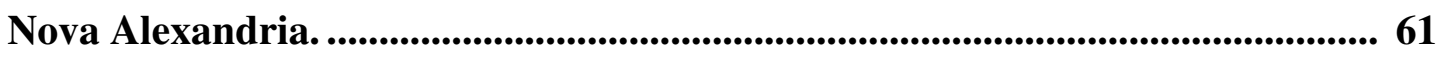

Figura 6 - Página interna do livro "As aventuras de Robinson Crusoé em cordel” -

Editora Nova Alexandria. .................................................................................. 61

Figura 7 - Capa da revista "As aventuras de Robinson Crusoé"

(literatura de cordel) - Editora Luzeiro ........................................................................ 62

Figura 8 - Página interna da revista "As aventuras de Robinson Crusoé”

(literatura de cordel) - Editora Luzeiro ................................................................62 62

Figura 9 - Cartoon - autor: Clive Goddard.......................................................... 63

Figura 10 - Cartoon - autor: Fran ............................................................................ 64

Figura 11 - Quadro: Mulher Pesando Ouro (Jan Vermeer- 1632-75)................. 107

Figura 12 - Robinson Crusoe - Washed Ashore After Shipwreck....................... 131 



\section{LISTA DE QUADROS}

Quadro 1 - Resultados de busca pelo nome do autor no Google......................... 38

Quadro 2 - Pontos positivos e negativos apontados por Robinson ..................... 115 



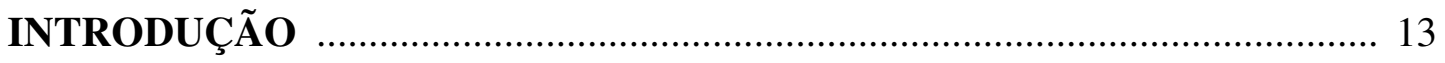

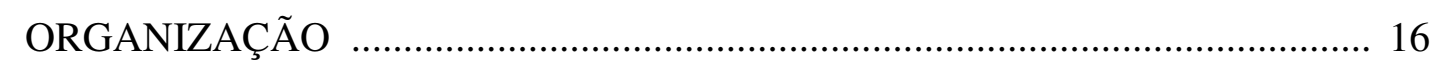

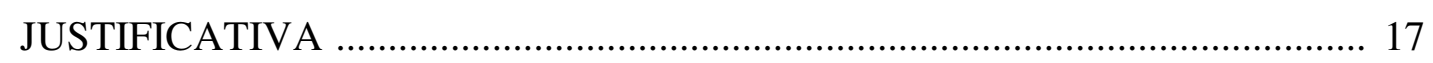

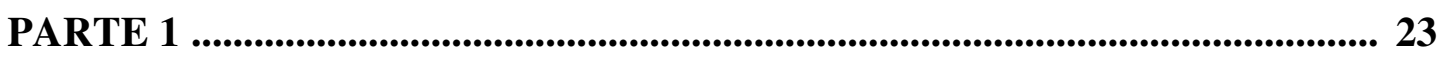

AUTOR OBRA PESQUISA DENTRO DA CADEIA DISCURSIVA ............... 25

ALGUNS FIOS DA CADEIA DISCURSIVA ................................................... 38

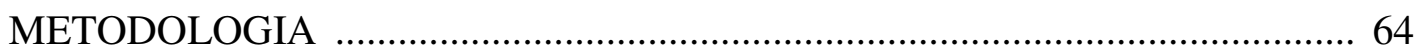

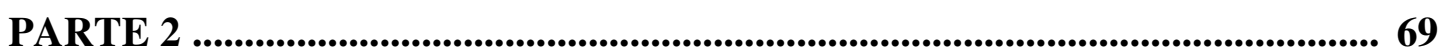

A CONCEPÇÃO DIALÓGICA DA LINGUAGEM ......................................... 71

APREENSÃO DE ENUNCIADOS E DISCURSOS: PASSOS

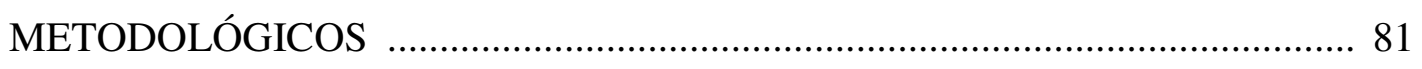

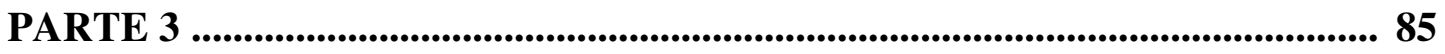

ROBINSON CRUSOÉ: A DIALOGIA DA LINGUAGEM NA

ILHA DO DESESPERO ............................................................................. 87

ATIVIDADE MENTAL, ENUNCIAÇÕES E MEIO EXTRAVERBAL ............. 87

O RELATO AUTOBIOGRÁFICO: ENUNCIADOS, DIALOGIA, DUALIDADE NO

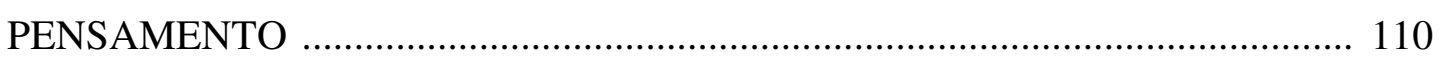

PARTE 4 ....................................................................................................................................... 121

A CONSTRUÇÃo de CONSIDERAÇÕES FINAIS DESTE PERCURSO

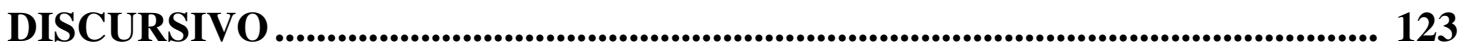

EM BUSCA DE UMA COMPREENSÃO CRIADORA: A DIFÍCIL TAREFA DO

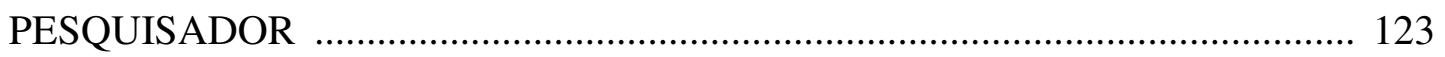

NOTÍCIA SOBRE UM NÁUFRAGO ................................................................. 133

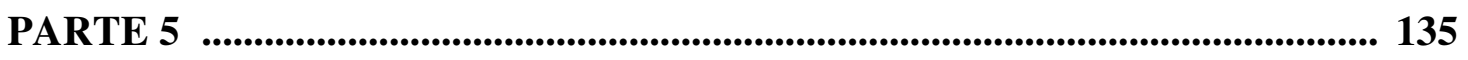

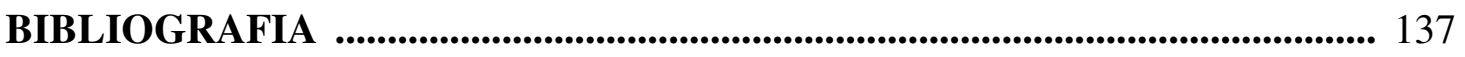

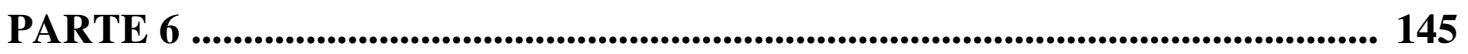

ANEXO A - Poema - Apague as pegadas - Bertolt Brecht...................................... 147

ANEXO B - Robinson Crusoé em diferentes culturas ........................................... 151

ANEXO C - Atos de linguagem ............................................................................... 157

ANEXO D - E-mail: Portal do Bibliotecário ........................................................ 171 



\section{INTRODUÇÃO}

Fôssemos infinitos

Tudo mudaria

Como somos finitos

Muito permanece

Bertolt Brecht

Discursos e tempos dialogam, numa criação conjunta de linguagem e história. A palavra faz o diálogo entre tempos, entre o presente e a tradição, entre mim e o outro. Nos diálogos estabelecidos com o passado não se busca retomar, de forma automatizada, a nomeação de fatos e produções humanas que foram criados e validados socialmente; procurase, antes de tudo, a permanente reconstrução de sentidos que alicerçará os discursos do presente. Nessa perspectiva, manter os elos com a cultura e a memória pela via da linguagem é tentar dialogar simultaneamente com o presente e o passado (com diferentes tempos e visões de mundo), em busca da vitalidade da tradição, nem sempre reconhecida como existente; é tentar ouvir os mortos pela possibilidade que a linguagem escrita nos oferece, pela fluidez da palavra/signo.

Ouvir os mortos para dialogar com os vivos. Estabelecer trocas culturais alicerçadas na experiência dos homens, finita por um lado, mas passível de incorporar-se ao acervo simbólico de toda a humanidade, pois a especificidade da cultura humana é a sua "capacidade de entrar em comunicação com o outro e de proceder a uma troca", sob diversas formas, como nos ensina Jeanne Marie Gagnebin (2006).

Imbuída dessas premissas e levada por indagações do tempo presente, faço uso da palavra para compor um trabalho acadêmico na área de Linguagem e Educação. Este tem como foco uma obra literária do século XVIII - Robinson Crusoé, de Daniel Defoe. Nesse diálogo entre passado e presente, muitas vozes irão se entrecruzar, portando marcas ideológicas. Algumas poderão ser identificadas, outras parecerão ressoar de forma sutil ou mesmo imperceptível, ainda que com a marca de sua presença. Elas ecoarão do Iluminismo, de uma Inglaterra setecentista em transformação, de diferentes representações literárias, de estudos de linguagem, de filósofos de várias épocas, de experiências de falas, leituras e escritas... 
Tanto quanto Robinson Crusoé viveu surpreendentes aventuras em sua ilha deserta, não foi menos surpreendente aventurar-me, como pesquisadora, dentro de uma cadeia discursiva do porte em que se encontra este clássico tantas vezes reeditado. Aventurar-me de forma solitária, na tentativa de realizar uma compreensão criadora, conceito bakhtiniano pelo qual, num movimento de aproximação e posterior afastamento, o leitor pode ampliar a construção de sentidos. Diz Bakhtin (2003, p.366):

No campo da cultura, a distância é a alavanca mais poderosa da compreensão. A cultura do outro só se revela com plenitude e profundidade (mas não em toda plenitude, porque virão outras culturas que a verão e compreenderão ainda mais) aos olhos de outra cultura. Um sentido só revela as suas profundidades encontrando-se e contactando com outro, com o sentido do outro: entre eles começa uma espécie de diálogo... Colocamos para a cultura do outro novas questões que ela mesma não se colocava: nela procuramos respostas a essas questões, e a cultura do outro nos responde, revelando-nos seus novos aspectos, novas profundidades de sentidos.

Que perguntas, então, podem ser feitas a essa obra do século XVIII, permanentemente reeditada? Que ampliações de sentidos a leitura dessa obra pode possibilitar, se iluminada por formulações teóricas de séculos posteriores? Que relações essa obra mantém com a ideologia do nosso cotidiano? Quais universos ligam-se à sua criação, engendrando-a, como fatores gestacionais, direta ou indiretamente ligados a ela?

Muitas vezes já se perguntou sobre os sentidos da obra de Defoe, inclusive, em relação ao leitor do mundo contemporâneo. Minha pergunta inicial é da seguinte ordem: Como me aproximo da obra de Defoe? Por que me aproximo dela?

Aproximo-me com a crença de ser um elo na cadeia de enunciados que tratam dessa obra; encontro-me permeada por leituras de muitos autores que foram compondo minha história de estudos durante o curso de pós-graduação; alimentada por histórias de leituras que se remetem à minha infância com livros nas estantes de casa; embalada por imagens de meu pai folheando dicionários para compor charadas e palavras cruzadas; envolvida por livros em condição de avaliação para compor acervos de bibliotecas públicas e escolares; instigada por análises de estudiosos a respeito do mundo onde nos cabe atuar; mobilizada por alunos para quem a palavra representa um desafio assustador e paralisante.

Aproximo-me com a consciência de ter escolhido como eixo teórico uma complexa obra, a do Círculo de Bakhtin, distante de dogmatismos e de concepções autoritárias, e em relação à qual meus estudos são passos de uma longa jornada. 
Encontro-me inserida entre os que se preocupam com a veiculação de obras clássicas para crianças e jovens brasileiros, com a valorização do patrimônio cultural.

E por que, entre tantas obras clássicas adaptadas para o público infantil e juvenil, a escolha recaiu sobre Robinson Crusoé?

A grande quantidade de reedições da obra chamou minha atenção no trabalho desenvolvido na Biblioteca Monteiro Lobato para composição da Bibliografia Brasileira de Literatura Infantil e Juvenil. Publicadas por diferentes editoras, adaptadas por diversos autores, com projetos gráficos bastante variados, as aventuras do náufrago podiam ser contadas em 70 ou 300 páginas. A atividade contínua de leitura de obras dirigidas a crianças e jovens com vistas à avaliação e seleção de acervos, a constante reflexão e discussão sobre questões vinculadas à formação de leitores e literatura com o grupo de resenhadoras, o contato com a diversidade de publicações do mesmo título levaram-me a pensar: afinal, que Robinson Crusoé nossas crianças estão lendo? Além disso, por entender o tempo em que vivo como paradoxal - referências de solidão na multidão, manifestação de verborragia e falta de sentidos, comunicação instantânea e ausência de diálogo - a situação vivida por um personagem absolutamente solitário criou um contraponto que desencadeou várias questões para mim: se, rodeado por muita gente nas cidades, imerso em linguagem, o homem moderno sente-se vazio e perdido, então, que sentido teria a permanência da linguagem na vida do náufrago que viveu, sozinho, por 25 anos em uma ilha? Como o personagem a teria viabilizado na ausência de interlocutores? Ao usar a linguagem na ilha, Robinson praticava um ato de loucura ou, ao contrário, preservava sua humanidade e sua sanidade mental?

A partir daí, busquei refletir sobre o funcionamento da linguagem na condição do personagem que esteve concretamente só, diferentemente da condição de se estar só no meio da multidão; viu-se apartado do mundo da cultura, mas estabeleceu diálogo permanente com ela. E me perguntei: o que faz a diferença?

Ao fazer essa indagação, deparei-me com as alavancas de uma busca - o que faz a diferença entre o homem que se sustenta a si mesmo com recursos internos num meio inóspito, e o homem que, favorecido por sofisticados recursos externos, numa civilização tecnológica, naufraga em meio ao esvaziamento de sua existência? Nesse movimento de procura, a obra de Daniel Defoe, com seu personagem solitário, sobressaiu-se como uma rica oportunidade de leitura e reflexão. Reflexão que se insere no campo da educação de nossas crianças e jovens, aprendizes da sociedade digital, usuários da comunicação instantânea e multifacetada, do mundo dos "links", "delets" e "mouses". 
A pesquisa realizada desenvolveu-se dentro da área das Ciências Humanas. Estas são entendidas, pelo pensador russo Mikhail Bakhtin (apud BRAIT, 2006, p.98), "como ciências do texto, pois o que há de fundamentalmente humano no homem é o fato de ser um sujeito falante, produtor de textos". Nessa concepção, tanto o pesquisador quanto o sujeito pesquisado são produtores de textos, o que vai criar uma situação de diálogo; porém, o texto de um não deve emudecer o do outro. Assim, ao desafio de manter relações dialógicas com o objeto de estudo escolhido, somou-se outro: o da elaboração de um discurso que desse conta da complexidade do diálogo, de forma clara para seus leitores.

Em consonância com as ideias de Bakhtin, o discurso apresentado neste trabalho constitui e é constituinte do contexto em que é realizado, e dirige-se a um auditório social definido. Este, a princípio, abarca educadores com experiências de leituras aguçadas e reflexivas sobre a educação e a cultura, na expectativa de um diálogo analítico e crítico de uma produção que, ainda em estado de amadurecimento, revela inquietações quanto a questões ligadas à linguagem verbal e, portanto, ao humano. Também encontram-se, na expectativa desse auditório, os leitores atentos às condições culturais em que vivem a infância e a adolescência no Brasil, comprometidos com atos de leitura e escrita nas salas de aula e nos ambientes virtuais, escolares ou não; profissionais ligados, por diferentes maneiras e em várias instâncias, à produção de livros para este público específico.

\section{ORGANIZAÇÃO}

A partir desta introdução, que explanará sobre a justificativa do trabalho, segue-se a indicação de sua organização, em quatro partes:

Parte 1 - Autor obra pesquisa no interior da cadeia discursiva...

Parte 2 - A concepção dialógica da linguagem

Parte 3 - Robinson Crusoé: a dialogia da linguagem na Ilha do Desespero

Parte 4 - A construção de considerações finais deste percurso discursivo

- em busca de uma compreensão criadora: a difícil tarefa do pesquisador 


\section{JUSTIFICATIVA}

Com a atenção voltada às questões de linguagem, uso de trocas simbólicas entre sujeitos da educação e cultura, considero de fundamental importância que a educação contemporânea atente para o uso da palavra enquanto interação verbal e construção de sentidos. Preservar a tradição, inserir-se de modo ativo nas novas formas de se produzir cultura, participar de uma rede em um mundo globalizado, de modo virtual ou não, são ações extremamente desafiantes para todas as gerações.

Pensador da cultura, o sociólogo polonês Zygmunt Bauman aponta uma liquidez das sociedades contemporâneas, dada sua condição de imprecisão de limites e fluidez constante e constitutiva. Ao que alguns estudiosos chamam de pós-modernidade, Bauman nomeia "modernidade líquida", tomando a fluidez dos líquidos como metáfora dos tempos atuais.

Para ele, a modernidade foi, desde seu início, um processo de liquefação, de "derretimento dos sólidos", ou seja, de diluição do "que quer que persistisse no tempo e fosse infenso à sua passagem ou imune a seu fluxo" (BAUMAN, 2001, p.9) ${ }^{1}$. No entanto, o autor aponta diferenças no desenrolar desse processo. Em seu ponto de vista, a modernidade, em seus primórdios, repudiava uma tradição, uma rigidez de usos e costumes engessadores e limitadores de escolhas e ações individuais. Sua ideia de desintegração era acompanhada pela proposta de instalação de uma nova ordem "mais "sólida" "2. A constituição dessa nova ordem, assim, derreteu estamentos e moldou classes sociais (com seus padrões, códigos, regras) nas quais os indivíduos deveriam se realocar. Nos tempos atuais, porém, o traço de "derretimento de sólidos", constitutivo da própria modernidade, apresenta um novo sentido. Os padrões, códigos e regras que poderiam servir como orientação "estão cada vez mais em falta" ${ }^{3}$. Padrões de interação estão se liquefazendo, e Bauman alerta que "manter os fluidos numa forma requer muita atenção, vigilância constante e esforço perpétuo - e, mesmo assim, o sucesso do esforço é tudo menos inevitável"4. Além disso, ele diz que outros sólidos que estão se derretendo "são os elos que entrelaçam as escolhas individuais em projetos e ações coletivas - os padrões de comunicação e coordenação entre as políticas de vida conduzidas

\footnotetext{
${ }^{1}$ Para maior esclarecimento dos conceitos de fluidez e solidez, bem como de suas relações, ver: "Ser Leve e Líquido” (prefácio). In: BAUMAN, Z. Modernidade líquida. Rio de Janeiro: Jorge Zahar Editor, 2001.

${ }^{2}$ Ibidem, p.10.

${ }^{3}$ Ibidem, p. 14.

${ }^{4}$ Ibidem, p. 15 .
} 
individualmente, de um lado, e as ações políticas de coletividades humanas, de outro" Vivemos a versão individualizada e privatizada da modernidade.

Essas colocações remetem-nos a Roland Barthes (2003) quando fala em acídia moderna; compartilhamos com Bauman a ideia de que a sociedade líquida traz, em seu bojo, liberdade, insegurança, contínua modernização com obsessão pelo novo, numa busca de satisfação nunca alcançada; tais condições, a nosso ver, podem ser fatores que induzam à acídia, o desinvestimento num modo de vida, mas que não significa, contudo, perda da fé. Segundo Barthes, a acídia liga-se a um gênero de vida e interessa ao homem moderno. Pelas próprias palavras de Barthes (2003, p.43) somos levados a entender o porquê:

Acídia: momento repetido, espalhado, insistente, em que nós estamos fartos do nosso modo de vida, de nossa relação com o mundo (com o 'mundano'). Posso despertar uma manhã e ver desenrolar-se diante de mim o programa de minha semana, na ausência de qualquer esperança. Repetição, retorno: as mesmas tarefas, os mesmos encontros e, no entanto, nenhum investimento, mesmo se cada parte desse programa é suportável, ou, por vezes, agradável. $[\ldots]$

Acídia (moderna): quando não se pode mais investir nos outros, no Vivercom-alguns-outros, sem poder, entretanto, investir na solidão.

As reflexões dos dois pensadores fornecem-nos alicerces para pensar sobre as questões que nos envolvem. Se os padrões de interação estão se liquefazendo, se a sociedade chegou a tal patamar de individualização que compromete projetos e ações coletivas, se o homem vive um paradoxo entre "estar só e estar com", certamente o funcionamento da linguagem e das trocas culturais está em condições de comprometimento de sua vitalidade e riqueza. Nesses momentos, torna-se imprescindível lembrar o que já sabemos, refletir para aprender, buscar caminhos que justifiquem o investimento na vida vivida e... escrever - ações deixadas como legado às novas gerações.

Por isso retomamos as ideias de que o homem nasce em um mundo já dado, em permanente transformação e nunca acabado; nasce duas vezes, concomitantemente, para a vida e para a cultura; morre para a vida, mas pode imortalizar-se pela criação cultural; vive sua vida individual, na interação com outras; constrói seu mundo interior, em dialogia com o mundo exterior. Parece ser Um e também ser, pelo menos, Dois, ao mesmo tempo.

Assim como a vida é dialógica, a cultura também o é. Assim como o homem é constitutivamente incompleto, a linguagem também o é; sua palavra, carregada de conteúdo vivencial, comporta duas faces: a do locutor e a do interlocutor. E por isso a questão do Outro é relevante ao se estudar o homem: "a alteridade define o ser humano, pois o outro é

\footnotetext{
${ }^{5}$ Ibidem, p. 12.
} 
imprescindível para sua concepção" (BARROS, 2005, p.28). Assim, identidade e alteridade também mantêm uma relação dialógica.

Nos estudos das ciências humanas, sob uma ótica bakhtiniana, vemos o homem sendo considerado um produtor de discursos que não são vistos como oriundos do seu psiquismo individual, mas considerados em dialogia uns com os outros, ou seja, em interação real e contínua. Diz Bakhtin (1999, p.123): “A interação verbal constitui assim a realidade fundamental da língua". Expressos por instituições ideológicas (imprensa, literatura, ciência etc.), por conversas cotidianas, na oralidade ou na forma escrita, os discursos acham-se inseridos numa grande cadeia discursiva, mantendo relações com outros discursos, passados, contemporâneos a eles e mesmo futuros, visto serem criações ideológicas. Por isso, acham-se entranhados nos contextos históricos e sociais em que são criados. Como atos de fala impressos, os livros também são discursos e constituem elementos da comunicação verbal.

Assim, estar atento ao humano é estar atento a seus discursos; dialogar com livros é encontrar Outros e realizar trocas culturais. É voltar-se para o grande repositório de nossa memória e experiência, para uma "biblioteca universal", no dizer de Alberto Manguel, considerada como algo vivo e não simplesmente como depósito de um passado. O autor diz (2001, p.85): "Escrever o passado, dialogar com a história foi, como nós sabemos, o ideal humanista, o ideal já colocado por Nicholas de Cusa em 1440”.

Num mundo de "links", "delets" e "mouses", como tem se colocado a questão das relações de trocas simbólicas?

"Links" podem expandir o universo cultural e ampliar fronteiras, mas podem, do mesmo modo, ser agentes de fragmentação; “delets" são passíveis de atuar sobre a memória, num trabalho salutar de esquecimento ou, no sentido do poema brechtiano ${ }^{6}$, de apagamento de rastros, esvaindo o passado num rápido movimento de dedos. O ligeiro deslizar de "mouses" acompanha a agilidade de uma escrita que emerge de/e constrói novas formas de pensamento.

Sobre estas questões, reportamo-nos novamente a Alberto Manguel em suas considerações expressas no texto "A biblioteca de Robinson Crusoé”. Concordamos com ele que possíveis perdas são responsabilidade dos homens e não das tecnologias em si mesmas, quando preferimos, deliberadamente, o esquecimento à lembrança (“[...] we alone are to blame when we deliberately choose oblivion over recollection") ${ }^{7}$.

Manguel entende que a World Wide Web (ou, simplesmente, www) obsta um sentido de passado porque o seu tempo é o presente, com a velocidade do pensamento, em um

\footnotetext{
${ }^{6}$ Ver poema no Anexo A.

${ }^{7}$ Ibidem, p. 89.
} 
espaço aparentemente sem fronteiras e inabitado (afora o fato de que o inglês é o idioma adotado, não há nacionalidades na web); porém, ela não pode ser responsabilizada por uma ausência de nossos laços com o passado. A incapacidade de fazê-lo tem sido do homem que, por não dialogar com o passado, condena-se a falar em um "vazio onde nenhuma voz humana pode ressoar" (2001, p.85). Nesse sentido, o autor afirma que a biblioteca de Robinson Crusoé poderia ter sido a ferramenta essencial da construção de sua nova sociedade.

Imbuídos dessas concepções é que iremos dialogar com Robinson Crusoé, o livro de Daniel Defoe, publicado em 1719 e presente no cânone de obras clássicas.

Crusoé é um náufrago com quem o leitor compartilha experiências. Logo após o naufrágio de seu navio e chegada a uma ilha deserta, o personagem viu-se sem recursos. Como sobreviver? - era a pergunta que se fazia. Sem companheiros, com as mãos vazias, sem formas de comunicação, a salvação que lhe ocorreu foi tentar recuperar materiais do navio, antes que ele soçobrasse de vez. A concretude dos despojos conseguidos representou um alento, mas ela transcendia sua materialidade física e os materiais recolhidos constituíam, além de bens concretos, bens simbólicos. Assim, mesmo apartado do mundo da cultura pelo naufrágio, Robinson Crusoé a trazia consigo, internalizada; sua vida física fora preservada da morte, e seu mundo, embora ele não o soubesse, também não submergira no afundamento do navio. O que ele possuía, sem saber, eram recursos internos não visíveis. O mundo cultural estava presente pela linguagem e, por longos 25 anos, a linguagem foi seu sustento simbólico. Foi esta dimensão da narrativa que se tornou a seiva geradora e alimentadora de nossa hipótese de trabalho, explicitada na página 66.

Assim, a obra revela especial interesse para o nosso estudo, na medida em que acreditamos na necessidade de resgatar a força da palavra no tempo presente.

A palavra está ameaçada - é uma constatação inquietante para os envolvidos em formação, principalmente, de novas gerações. E este é o título da obra da poeta, ensaísta e linguista argentina Ivonne Bordelois (“A palavra ameaçada”) em que ela diz considerar a cultura global do capitalismo selvagem em que vivemos "uma empresa destinada a demolir nossa consciência da linguagem", sendo "incrivelmente eficaz nesse sentido" (2005, p.24). Esclarecendo não se referir a "um conjunto de multinacionais perversas dedicadas a estragar a linguagem", ela entende que, por essência, a cultura consumista, por sua própria natureza, opõe-se à linguagem. São suas palavras (2005, p.25-26): 
Quando apalpamos a incrível estreiteza do espectro verbal dos jornais, da televisão, da literatura best-seller de nossa época, quando a conversa (uma forma de poesia mútua se for verdadeira) é despejada violentamente dos lugares de encontro pelos alaridos infantis e patéticos do pior rock, quando a letra das músicas mais populares desce aos infernos da monotonia e da estupidez, é nossa linguagem (e através da linguagem nós mesmos, no mais profundo de nossa identidade) que é atacada e destruída.

Bordelois aponta ser uma prática de violência contra a linguagem defini-la exclusivamente como meio de comunicação. Em sua concepção, a linguagem é um prazer sagrado, que manifesta um investimento de libido em palavras que nos relacionam com os outros e com nós mesmos. E aí reside um poder que prevalece sobre as operações intelectuais. Um poder que não devemos reduzir ao nada sem-sentido, para o qual fechamos nossos ouvidos. Trazendo à discussão "a incapacidade dos seres humanos de nos escutar uns aos outros", Bordelois vale-se do mito de Orfeu e Eurídice.

Orfeu era o único humano que, ao tocar a lira, era capaz de produzir harmonia. Somente ao som de sua voz, o barco de Jasão pôs-se ao mar, em busca do Velocino de Ouro. Apaixonado por Eurídice, com quem tivera a ventura de casar-se, entra em desespero ao vê-la morta, vítima da picada de uma serpente. A única forma de reencontrá-la era ir aos Infernos, ao Hades, lugar de trevas, onde não era permitida a entrada dos vivos. O barqueiro Caronte recusa-se a transportar Orfeu, mas ao som de sua melodia, cede aos seus pedidos. A mesma magia seu canto provocou no Reino dos Mortos, e Plutão autorizou a partida de Eurídice junto com seu esposo. Mas havia uma condição: Orfeu não poderia olhar pra trás enquanto estivesse na região infernal, pois, se assim o fizesse, perderia Eurídice para sempre. Na volta, tendo já descido do barco de Caronte e pousado no mundo dos mortais, Orfeu esquece-se do aviso e olha para trás, para o barco em que a amada ia a seu encontro. Eurídice, então, é reconduzida ao Hades e os Infernos se fecham aos versos de Orfeu.

$\mathrm{Na}$ análise desse mito, Bordelois considera que Orfeu tinha uma necessidade narcísica de ouvir apenas a si mesmo e, por isso, provoca a tragédia da volta de Eurídice ao inferno. Apropriando-nos dessa ideia, podemos dizer que a "não escuta", o desconhecimento da palavra do outro destrói o passado e inviabiliza a construção de um futuro.

Compactuando com a autora sobre a pobreza de significados das palavras e a existência de clichês no mundo de hoje, George Steiner (1990) também aponta o perigo das políticas totalitárias na manipulação da linguagem e da política de licenciosidade. Esta, segundo ele, ao "dizer tudo, e dizer com as mesmas palavras de feira, como todo mundo" (p.98), prejudica a capacidade de imaginar, de recriar. $\mathrm{O}$ autor entende as palavras reservadas a momentos de grande intimidade, como na privacidade do amor, prenhes de vitalidade e 
magia, detentoras de uma força profunda, que se perde quando expostas a uma exibição demasiadamente aberta.

Em tempos de crise da linguagem, em que o "deletar" pode significar não deixar rastros, não se comprometer, fazer sumir o passado, é importante que retomemos a reflexão sobre o uso da palavra.

Para isso, busco a palavra literária, a palavra que, engendrando mundos ficcionais, é capaz de refratar o mundo. Para Barthes, a literatura sabe muito sobre os homens, mas esse saber não é fetichizado; por isso, ele acredita que, se fossem eliminadas todas as disciplinas do ensino, a literatura deveria ser preservada. Do mesmo modo, segundo Bakhtin, toda obra literária é "imanentemente sociológica", vinculada indissoluvelmente à cultura de uma época. A esse respeito, esse autor cria uma bela analogia, valendo-se da imagem de refração produzida por um cristal $(2003$, p.195, 196):

Nela (obra literária) se cruzam forças sociais vivas, avaliações sociais vivas penetram cada elemento da sua forma. Por isso, a análise puramente formal deve tomar cada elemento da estrutura artística como ponto de vista da refração de forças sociais vivas, como um cristal artificial cujas facetas foram construídas e lapidadas a fim de refratar determinados raios de avaliações sociais, e refratá-los sob um determinado ângulo.

Considero, assim, que indagar as grandes obras literárias é uma busca para construir novos sentidos para a palavra e, portanto, para a vida humana. 


\section{PARTe 1}




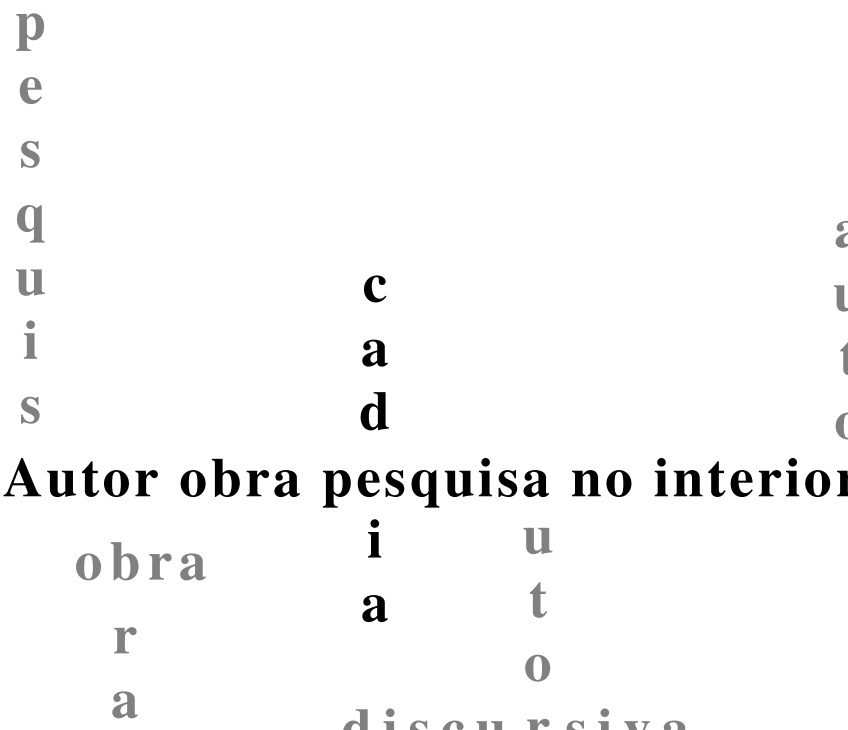

$\mathbf{a}$

$\mathbf{u}$

t

o p r

$\begin{array}{cccc}\text { Autor obra } & \text { pesquisa no interior de uma cadeia } \\ \text { o b r a } & \text { i } & \text { u } & \text { s } \\ \text { r } & \text { a } & \text { t } & \text { q } \\ \text { a } & & \text { dis c u r s i va } & \text { u } \\ & & \text { i } \\ & & \text { s } \\ & & \text { a }\end{array}$

Ao nomearmos e grafarmos o título da Parte 1 deste trabalho do modo como se apresenta, estamos sinalizando posturas assumidas perante o tema estudado, ou seja: forma, conteúdo e contexto estão essencialmente imbricados; o autor, a obra em estudo e a pesquisa aqui apresentada inserem-se em uma cadeia discursiva que não se esgota neles. Para estudar o autor e a obra remeti-me à biografia de Defoe, mas apreender as relações entre ele e sua criação implica o esforço de estabelecer a união existente entre eles, num movimento de vai e vem que se diferencia da postura de analisar a obra como alegoria da vida do autor. Como diz Dominique Maingueneau (2001, p.61), estudioso de linguística e análise do discurso, "A vida não está na obra, nem a obra na vida, e contudo elas se envolvem reciprocamente”. Citando Blanchot, que a respeito deste assunto discorre sobre Melville, Ahab e Moby Dick, autor e personagens de uma inesquecível história de perseguição e acerto de contas no mar, Maingueneau fala do "paradoxo de Ahab"- o capitão só encontra Moby Dick, a baleia, no livro de Melville; por outro lado, só a ocorrência de um encontro como esse permitiria a criação da obra. Dessa forma, a obra só pode surgir se encontrar sua efetuação numa existência. É por isso que o autor vale-se da expressão "bio/grafia" para indicar o movimento recíproco da vida para a grafia e da grafia para a vida.

É dessa forma que tentaremos ver Defoe em Robinson e Robinson em Defoe, buscando fugir de artificializações para conformar nosso estudo a um quadro teórico. Se, 
como diz Maingueneau, "a vida do escritor está à sombra da escrita, mas a escrita é uma forma de vida" (2001, p.47), nós nos perguntamos como Defoe geriu sua participação no campo discursivo de seu tempo enquanto escritor.

Até chegar à produção da obra que o celebrizou, realizada perto de seus 60 anos, Defoe fez uso de sua grande habilidade com a palavra, escrevendo panfletos, jornais e livros. Seus enunciados escritos brotaram em uma Inglaterra convulsionada por perturbações políticas e religiosas. Por eles foi condenado e por eles, também, resgatado.

Nas turbulências religiosas que ocorriam na Inglaterra do seu tempo, com o reconhecimento da Igreja Anglicana e a dissidência dos puritanos, Defoe era um dissidente. As perseguições de que esse grupo era vítima mobilizaram-no a escrever um panfleto, em 1702, chamado "Shortest Way with the Dissenters"

But justice is always violence to the party offending, for every man is innocent in his own eyes.

Justiça é sempre violência para o lado ofendido Pois todo homem é inocente perante si mesmo.

A presença de ironia (figura de linguagem cujo uso foi corrente na modernidade) em defesa da eliminação dos dissidentes, a princípio, passou despercebida. Mas, ao vir à tona o teor da sua escrita, a resposta foi a condenação à exposição no pelourinho e à prisão. A ajuda de seus amigos, contudo, tornou o fato uma forma de revalorização do escritor e, de dentro da prisão, Defoe novamente escreveu um poema em resposta - "Hymn to the Pillory" -, ridicularizando o sistema judiciário vigente.

\footnotetext{
${ }^{1}$ Fonte: Daniel Defoe Quotes. Disponível em http://www.luminarium org/eightlit/defoe/defoequotes.htm. Tradução livre.
} 


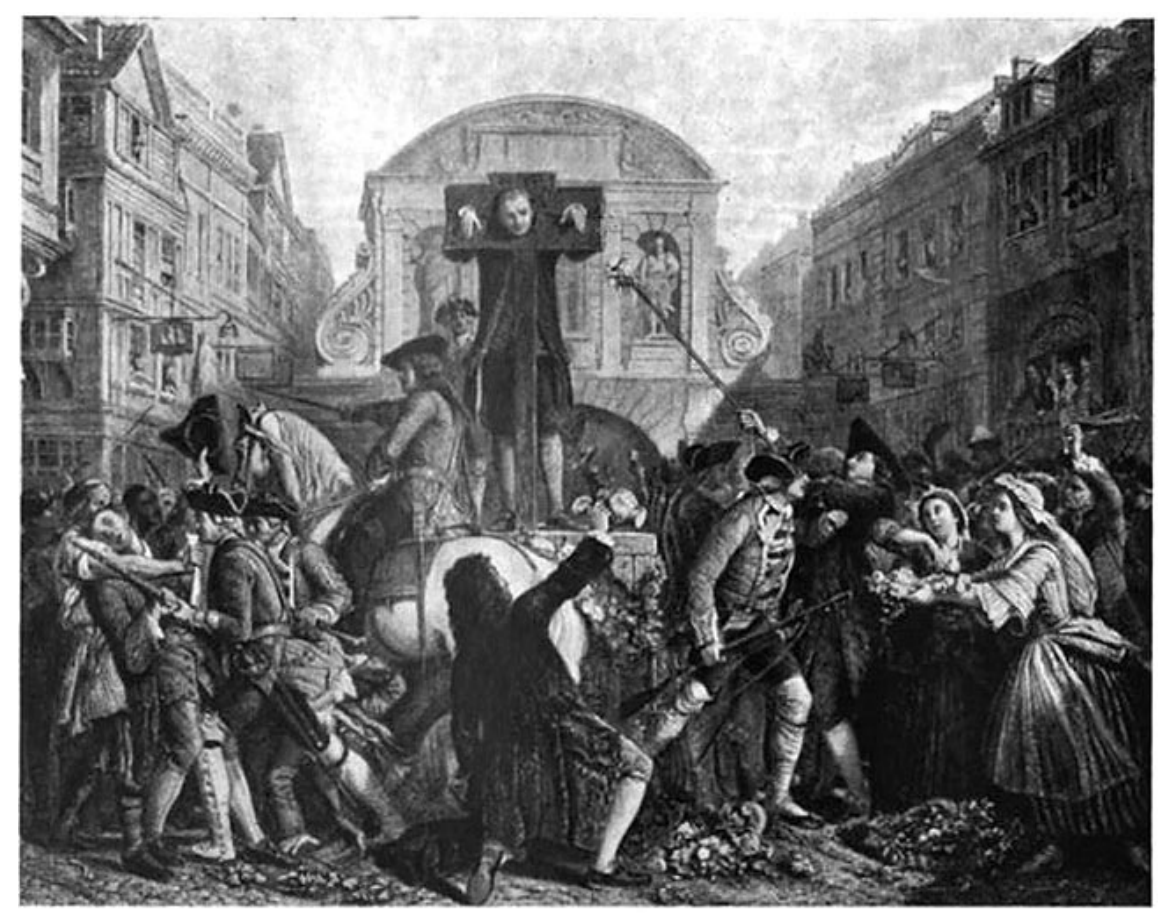

DANIF.L DE FOE IN THE IILLORY AT TESHPLE BAK

From an engraving by J. S. Armytage, after a painting by E. Crowe.

In Hugh H. L. Bellot's The Inner and Middle Temple. Methuen, 1902.

Figura 1: Daniel Defoe no pelourinho.

Embora fosse um jornalista profundamente enraizado nas questões do seu tempo, Defoe era um dissidente, um homem perseguido, o que o colocava à margem da sociedade, abrindo lugar para o escritor. Essa posição entre integração e marginalidade é o que Maingueneau chama de paratopia, uma condição de um "não-lugar", uma condição paradoxal vivida por quem se acha impossibilitado de permanecer em situação de estabilidade. $\mathrm{Na}$ tensão de uma negociação entre os dois polos, o escritor vê-se incitado a produzir enunciações no campo literário, onde se insere.

Imerso na cadeia discursiva de seu tempo, Defoe atuava politicamente com seus textos. Aos críticos do rei William III, em virtude de sua origem estrangeira, respondeu com o texto "True Born Englishman"2 (1701) em que se vale da sátira, e do qual reproduzimos alguns trechos:

From this amphibious, ill-born mob began,

That vain ill-natured thing, an Englishman.

Dessa turba anfíbia e mal-nascida se fez Esse ser vaidoso e ranzinza: o inglês.

\footnotetext{
${ }^{2}$ Fonte: Daniel Defoe Quotes. Disponível em http://www.luminarium org/eightlit/defoe/defoequotes.htm. Tradução de Clara Alícia Allain.
} 
And of all plagues with which mankind are curst, ecclesiastic tyranny's the worst.

\section{E de todas as pragas de que a humanidade é acometida} A tirania eclesiástica é a mais sofrida.

Pride, the first peer, and president of Hell.

Orgulho, o primeiro lorde, e presidente do Inferno.

Whenever God erects a house of prayer, The devil always builds a chapel there; And 'twill be found, upon examination, The latter has the largest congregation.

Sempre que Deus ergue uma casa de oração, O demônio constrói uma capela no mesmo chão; E se constata, com cuidadosa visão Que a congregação do último tem maior amplidão.

Wealth, howsoever got, in England makes Lords of mechanics, gentlemen of rakes; Antiquity and birth are needless here;

'Tis impudence and money makes a peer.

Seja como se a conquista, na Inglaterra, a riqueza Faz de mecânicos, senhores, e de devassos, nobreza; Berço e origem são desnecessários nesta terra; Insolência e dinheiro são o que fazem um lorde.

Great families of yesterday we show,

And lords whose parents were the Lord knows who.

As grandes famílias de antanho alardeamos, E nobres cujos pais só Deus sabe quem foram.

An Englishman will fairly drink as much As will maintain two families of Dutch.

Um inglês sozinho gastará tanto com bebida

Quanto duas famílias holandesas despendem com comida.

Foe, que acoplou "De" a seu nome, foi dono de um jornal chamado Review, em circulação de 1704 a 1713, com três tiragens semanais e artigos quase todos de sua autoria (lembremo-nos de que o trabalho jornalístico lida com as questões da sua atualidade). Se tivesse seguido os desejos de seu pai de ser ministro da religião puritana, ainda assim o uso da palavra ter-lhe-ia sido útil. Mas Defoe preferiu outros caminhos. Escrevia muito, às vezes valendo-se de pseudônimos (J. Robert Moore calcula em 87 o número de personalidades 
fictícias assumidas por ele $)^{3}$. Apesar da intensa atividade com a escrita e do envolvimento em inúmeros empreendimentos, sua vida financeira foi repleta de altos e baixos, com bancarrotas significativas. Suas matérias apresentavam diversidade de gêneros e interesses. Uma lista bibliográfica de seus escritos, "A Checklist of the Writings of Daniel Defoe”, elaborada pelo já citado Moore e considerada referência, aponta mais de 500 títulos publicados, entre panfletos e livros, versando sobre os mais variados assuntos ${ }^{4}$ :

[...] política, religião, geografia, filosofia, viagens, economia, magia, educação, moral, direito, história, pirataria, e dissemelhantes temas, e entre os quais se contam os sete ou oito volumes, cuja autoria Defoe nunca reconheceu explicitamente, que hoje consideramos como romances e pelos quais atribuímos um lugar a este autor na história da literatura inglesa.

Segundo Gualter Cunha, professor da Faculdade de Letras da Universidade do Porto, em Portugal, Defoe não perdia oportunidades para escrever, mesmo sobre um acontecimento eventual, como uma tempestade. E uma grande oportunidade apareceu com a história de Alexandre Selkirk, marinheiro que viveu solitário em uma ilha durante quatro anos, após os quais foi resgatado.

A situação paratópica vivida por Defoe levava-o a identificar-se com situações de "não-lugares" como histórias de aventureiros e piratas. A história de um homem solitário numa ilha dialogou com o escritor e seu tempo e engendrou a narrativa de Robinson. Eram tempos de ascensão econômica da Inglaterra como nação capitalista, conflitos políticos com alternância de partidos no Parlamento (Whigs e Tories), questões de expansão do império, incluindo a anexação da Escócia (em que Defoe atuou como espião, enviando informações por cartas). Era também o tempo das Luzes, com as concepções do predomínio da razão, do poder do indivíduo e da ideia do progresso histórico em escala ascendente. Concepção de uma nascente sociedade de classes, com um tempo individual diferenciado, contraposto a um tempo coletivo e a um espaço público.

No diálogo entre a vida e a arte, a criação de Robinson Crusoé tem, em si, a paratopia de Defoe. A ilha é um cenário paratópico por excelência. Vivendo em terras brasileiras, antes do seu naufrágio, Robinson diz (p.41) ${ }^{5}$ : “[...] costumava dizer que vivia como um homem colocado numa ilha deslocada, onde não houvesse mais ninguém".

\footnotetext{
3 Apud CUNHA, G. Uma dupla direcção da escrita em Daniel Defoe: The Farther Adventures of Robinson Crusoé, ou, alguns bons ensinamentos da má literatura. Disponível em: <http://hdl.handle.net/10216/8798>. Acesso em: 04 dez. 2008.

${ }^{4}$ Ibidem, p. 190.

${ }^{5}$ As numerações relativas à paginação de excertos da obra Robinson Crusoé, em todo este trabalho, referem-se à publicação de livros de bolso Europa-América, número 108, volume duplo com texto integral, de abril de 1975.
} 
Robinson Crusoé, com a força da razão e da vontade pessoal, praticamente refaz o percurso realizado pela humanidade: da atividade extrativista passa à prática da agricultura e do pastoreio. Do abrigo na árvore, desce para a caverna e organiza uma habitação, uma casa, um castelo. Escreve e lê, valorizando a palavra/Palavra. Estabelece diálogos com Deus e se purifica, tal qual o anseio de um puritano fiel aos princípios de sua crença.

Para escrever sua criação e ser legitimado pela obra, o jornalista (que deu novos rumos a esse campo na Inglaterra) recorreu a uma narrativa de fatos, imprimindo-lhe um cunho realista. Com o distanciamento enunciativo criado pela figura de um editor, ele diz em seu prefácio:

A história é contada com modéstia, com seriedade e com uma aplicação religiosa dos acontecimentos para os efeitos a que os homens sensatos sempre os aplicam, como seja na instrução de outros com este exemplo e para justificar e honrar a sabedoria da Providência na total variedade dos nossos percalços, deixando-os ocorrer como desejam.

O editor acredita que o livro é simplesmente a narrativa dos fatos; não há nela nenhuma aparência de ficção [...].

Além disso, em busca de sintonia com o público leitor, vale-se da aventura para facilidade de compreensão e da utilização de variadas estratégias narrativas. Assim, Defoe procura

- estabelecer diálogos diretos com seus leitores:

- Comecei a fazer o meu diário, do qual vos dou aqui uma cópia (p.73).

- Ninguém que alguma vez leia este relato (p.90).

- O leitor teria pena de mim (p.120).

- Por favor, notem que tudo isto era o fruto de uma mente perturbada (p.190).

- Mas voltemos ao meu novo companheiro (p.201).

- Enquanto o ressentimento durou, podem estar certos de que todos os dias o espiava [em referência ao selvagem que salva das mãos dos canibais] (p.214).

- Fiz uma boa refeição - posso garantir-vos - [...] (p.230).

- apelar a digressões:

- Mas volto ao meu Diário (p.94).

- criar suspensão de acontecimentos:

- [...] sendo canibais, os matariam e comeriam, como se verá mais adiante (p.161).

- Mas cada coisa no seu lugar (p.179).

- escrever um relato autobiográfico.

- transcrever um diário escrito por Robinson. 
As formas escolhidas por Defoe para compor sua obra são indissociáveis do seu conteúdo e contexto de produção. O prefácio da obra já indica o objetivo de criar o efeito de verdade do texto literário, para lhe dar credibilidade. Em uso no século XVIII, tal procedimento traz à tona a importância do espaço privado, pois a verdade estará fundamentada na palavra individualizada. E, constitutivamente imbricado nesse processo, há a escolha por uma escrita autobiográfica de Robinson. A história individual legitima o ato de escrever. Citamos Goulemot (1991, p.394):

Porque um sujeito fala com sua própria voz aceitamos como verdadeiro o que ele nos conta sobre seu destino. O que fundamenta a verdade de seu relato é o íntimo, o privado, o que está além do público. Assim, cabe repensar numa nova óptica a voga dos romances na primeira pessoa. Sem dúvida, podemos ler neles a afirmação de um sujeito que participa de uma ideologia do mérito tão nova no século. Porém, devemos reconhecer paralelamente o movimento pelo qual a verdade se fundamenta numa palavra individualizada. O efeito de verdade deve-se então a esse reconhecimento íntimo de um sujeito que escreve por um sujeito que lê.

O leitor é tomado como testemunha, como um "voyeur" a quem se procura instruir. Com efeito, o discurso iluminista procura se legitimar. Diz Goulemot: "O homem do Iluminismo não pára de se questionar sobre seu direito à palavra e suas relações com a verdade" 6 . Ao falar sobre a face oculta de acontecimentos públicos, "as histórias secretas", o autor cita Eustache Lenoble ("História secreta das mais famosas conjurações, da conjuração dos Pazzi contra os Médici"): ${ }^{7}$

Tratam-se de duas maneiras diferentes as coisas que se decide dar a conhecer aos que sobre elas desejam instruir-se. A mais simples e mais comum é reduzi-la a preceitos de ordem didática [...]. No entanto, a mais sublime é emprestar a delicadeza da Arte para envolver esses preceitos em relatos de histórias ou de fatos que oferecem lições sem parecer oferecê-las e que, divertindo o espírito, insensivelmente o conduzem ao que queremos que saiba.

Vinculada à sua vida, às instâncias jornalísticas em que atuava, aos seus posicionamentos sociais e políticos, a inserção de Defoe no campo literário tem lhe atribuído um lugar inaugural na constituição do gênero conhecido como romance.

O romance, na concepção de muitos autores, como Giörgy Luckács e Marthe Robert, aparece ligado ao surgimento da classe burguesa; mas, pela ótica de Mikhail Bakhtin, a formação do romance dá-se por outros caminhos. Segundo José Luiz Fiorin, em sua leitura do pensamento bakhtiniano (2006, p.117):

\footnotetext{
${ }^{6}$ Ibidem, p.397.

${ }^{7}$ Ibidem, p.395.
} 
Para Bakhtin, o romance não é um gênero como qualquer outro. Seu aparecimento não está ligado à sociedade burguesa. Na realidade, o romance perpassa, segundo ele [Bakhtin], toda a história da literatura ocidental, da Grécia até nossos dias [...].

O romance é um gênero que, no interior de um sistema literário, solapa-o, revelando que seus limites são impostos, arbitrários e inadequados. $\mathrm{O}$ romance incorpora vozes que estavam fora do sistema [...].

Na perspectiva adotada neste trabalho, Robinson Crusoé é um romance porque esta forma de elaboração já é constitutiva de sua própria criação. Para tentar entender essa relação, é preciso, antes de tudo, conhecer mais detalhadamente a narrativa.

Ela nos fala de um jovem que, contrariando conselhos paternos ideologicamente eivados de valores religiosos cristãos, abdica da segurança e do conforto do lar e arrisca-se em aventuras pelo mar, fazendo comércio com lugares diferentes e estranhos à Inglaterra, onde morava. Em suas viagens, vive diferentes situações: tormentas no mar, naufrágios, prosperidade no cultivo de terras tropicais, escravidão. Em um de seus naufrágios, foi o único homem a sobreviver, chegando a uma ilha deserta. As vicissitudes e as saídas encontradas por esse jovem durante sua estadia no que ele chamou de "Ilha do Desespero" constituem a maior parte do enredo. Lidar com a satisfação das necessidades mais primárias do homem como conseguir alimentos, água doce para beber, condições de segurança para dormir, defender-se de ataques de animais são os seus primeiros desafios. Com exíguos recursos (apenas o que pôde conseguir dos restos do navio) começou a construir uma vida que se mostrava desafiante a cada momento: a necessidade de uma panela para fazer um caldo, um remédio para curar uma doença, um cesto para carregar produtos de coleta e colheita. O mais difícil era lidar com o desafio de viver uma vida silenciosa, sem contato humano e com a esperança (muitas vezes desesperançada) de abandonar a ilha e retornar à civilização. $\mathrm{O}$ personagem precisava dialogar com dúvidas e terrores, palavras do passado e remorsos; sustentar sua integridade física e humana, frente aos silêncios da terra e aos sons do mar. A escrita de um diário, possibilitada por uma quantidade limitada de tinta, registrou seus afazeres por um tempo. Mas foi a Bíblia, resgatada do navio, que se tornou a sua grande ponte com Deus, pelo poder da Palavra, especialmente durante o ataque de malária sofrido.

O sentido de lacuna de companhia humana revela-se uma arma de dois gumes, configurando um paradoxo: a marca de um pé na areia, encontrada de súbito, desencadeia uma inesperada sensação: pânico. O Outro desejado é, agora, temido, pois a pegada sugere, a ele, a possibilidade de encontro com selvagens, canibais. O temor faz o jovem náufrago ocultar sinais de sua existência na ilha, escondendo seus animais de criação, sua moradia, 
alertando-o para o perigo de disparar suas armas de fogo e andar desavisado, como antes fazia. Seu sono e sua vida tornam-se povoados de pesadelos. Mas a ameaça não se concretiza... pelo menos até dois anos após o incidente. Tempos depois, a presença de um grupo de canibais que aportara por algumas horas na ilha coloca-o em contato com um selvagem que ele salva da morte e que vai pôr fim aos seus 25 anos de completa solidão. As relações que se estabelecem entre ele, que já se considera um rei na ilha, e o recém-chegado são assimétricas, já que o primeiro salva fisicamente um selvagem, adotando, depois, uma postura de salvamento "simbólico", ao transmitir-lhe elementos da cultura europeia, julgada superior. São 28 anos de permanência na ilha, ao fim dos quais os dois homens partem do local. Unidos por três anos de convívio e experiências, Robinson Crusoé, tendo experimentado o poder de Deus e sua divina misericórdia, viaja para a Europa com seu fiel criado Sexta-Feira.

A partir de um melhor conhecimento da narrativa, de alguns dados sobre a inserção de seu autor no campo discursivo de seu tempo, da constituição da obra como romance, procuraremos estabelecer relações, visto que o gênero "vive do presente, mas sempre recorda o seu passado, o seu começo" (BAKHTIN, 2005, p.106).

Robinson Crusoé vive uma aventura que estabelece contato com um fato real, da contemporaneidade de Defoe, talvez o encontro de que fala Maingueneau ao citar "o paradoxo de Ahab”. Isso não retira dela elementos de fantasia, pois, como diz Jacqueline Held (1980, p.28), “do ponto de vista daquele que cria, a obra fantástica [...] encontra sua fonte numa experiência cotidiana, com personagens conhecidas, acontecimentos vividos [...]”; assim, o personagem vive uma história fantástica na condição de uma vida cotidiana real, mas que o faz viver em condições de limite. Ele dialoga consigo mesmo e com um Deus cristão, pela leitura da Bíblia. Em sua permanência na ilha experimenta o poder de Deus e a salvação da alma pelo caminho da culpa e da expiação dos pecados.

Esses dados remetem-nos a características da "sátira menipeia" ou "menipeias", que, segundo Bakhtin (2005), foi um gênero introduzido pela primeira vez por um erudito romano, Marco Terêncio Varro (116-27 a.C ${ }^{8}$ ) no século I a.C. Em seu desenvolvimento, as menipeias atingiram as épocas do Renascimento e da Reforma, chegando até os dias atuais. Uma particularidade da menipeia é, ainda segundo Bakhtin", ser uma "espécie de gênero ‘jornalístico' da Antiguidade, que enfoca com tom mordaz a atualidade ideológica”. E o autor cita as sátiras de Luciano, dizendo que "são plenas de alusões a grandes e pequenos

\footnotetext{
${ }^{8}$ Nota do tradutor da obra referida.

${ }^{9}$ Ibidem, p.118.
} 
acontecimentos da época, perscrutam as novas tendências da evolução do cotidiano, mostram os tipos sociais em surgimento em todas as camadas da sociedade [...]"10.

Uma outra particularidade citada pelo estudioso russo em sua obra "Problemas da Poética de Dostoiévski” e considerada a mais importante do gênero da menipeia é o fato de a fantasia e a aventura formarem uma unidade com vistas à experimentação de uma verdade filosófica. Retomemos, então, o que Defoe explicita em seu prefácio da obra, na condição de editor: "[...] seja na instrução de outros com este exemplo e para justificar e honrar a sabedoria da Providência na total variedade dos nossos percalços, deixando-os ocorrer como desejam [...]"; recordemos as palavras de Lenoble, já citadas anteriormente (página 31), e a menção de que princípios de moralidade e religião permeiam toda a narrativa de Robinson (conduta já presente em um texto de 1715, “The Family Instructor”, em que veiculava códigos de conduta familiar), e teremos mais elos entre o romance e a menipeia.

Os discursos de Defoe/Robinson dialogam com a religiosidade cristã e as formas coletivas e pessoais de devoção a Deus. A diferença de crenças e posturas em relação ao catolicismo, marcada pela Reforma Protestante e pelo Calvinismo (existência do purgatório, intercessão dos vivos, culto aos santos), subjaz nos silêncios do texto. A prática de leitura de Robinson, sozinho, com sua Bíblia, é um diálogo vivo com as palavras de François Lebrun em “As Reformas: devoções comunitárias e piedade pessoal” (1991, p.111):

O protestante se sabe eleito de Deus, eleição pessoal resultante, segundo Calvino, do 'conselho eterno de Deus pelo qual determinou o que queria fazer de cada homem'. Essa eleição, ao mesmo tempo, acarreta certeza e responsabilidade: certeza de figurar entre os eleitos, responsabilidade com relação a Deus, que salva. O católico deve, com a ajuda da graça, merecer a própria salvação por suas obras. O protestante deve viver segundo a lei, gratuitamente e sem contrapartida. Nisso reside a responsabilidade do fiel: ao contrário do católico, ele é liberado da angústia da morte e do Juízo, porém, ao acolher a Palavra e aceitar suas exigências, deve demonstrar que Deus o elegeu. Assim, o individualismo e o foro íntimo estão no âmago da teologia reformada. E é nesse sentido - porém só nesse sentido - que Claudel tem razão ao escrever: 'o protestante reza sozinho, mas o católico reza na comunhão da Igreja'.

Bakhtin diz que, na literatura do período da Reforma, teve amplitude a "literatura das portas do céu" com representações do gênero do "diálogo no limiar", situação que vemos expressa durante os ataques de febre de Robinson. E nos momentos em que ele diz "Os que sabem o que é ter a pena suspensa nos degraus do cadafalso, ou ser salvo de bandidos no momento em que se vai ser morto, ou que tenham estado em situações semelhantes, podem

\footnotetext{
${ }^{10}$ Ibidem, p.119.
} 
calcular qual a minha alegria [...]”(p.139), não somos remetidos à situação extrema de Defoe no pelourinho?

Gêneros cognatos da menipeia ressoam na linguagem de Robinson: o solilóquio, que é o diálogo consigo mesmo (diálogos internos do náufrago), e a diatribe, uma forma de diálogo com um interlocutor ausente, "fato que levou à dialogização do próprio processo de discurso e pensamento" (BAKHTIN, 2005, p.120). Isso nos remete, na obra de Defoe, à interação de Robinson com Deus.

O título original da obra era "The Life and Strange Surprizing Adventures of Robinson Crusoe, of York, Mariner: That lived Eight and Twenty Years all alone in an uninhabited Island on the Coast of America, near the mouth of the Great River Oroonoque; Having been cast on the Shore by Shipwreck, wherein all the Men perished but himself, With an Account how he was at last as strangely deliver'd by Pirates. Written by himself" ("A vida e as pasmosas, surpreendentes aventuras de Robinson Crusoé, marinheiro de York; Que viveu vinte e oito anos completamente só em uma ilha desabitada na costa da América, perto da foz do grande rio Orinoco; Atirado na praia por um naufrágio, no qual morreram todos, exceto ele, Com um relato de como foi afinal curiosamente libertado por piratas. Escrito por ele mesmo"). Foi publicada em 1719, e constava de uma trilogia. O segundo volume intitulava-se "The Farther Adventures of Robinson Crusoé: Being the Second and Last Part of his Life" (“As novas aventuras de Robinson Crusoé: Sendo esta a segunda e última parte de sua biografia") e foi editado no mesmo ano. Em 1720, Defoe publicou "Serious Refletions during the Life and Strange Surprizing Adventures of Robinson Crusoé: With his Vision of Angelick World” ("Reflexões graves de Robinson Crusoé, quando vivo, sobre as suas pasmosas, surpreendentes aventuras: Com sua visão do mundo angelical") ${ }^{11}$.

Embora reconhecido por sua destreza na escrita, Defoe foi criticado quanto à qualidade dos seus textos, tendo em Jonathan Swift um crítico mordaz. Disse ele (apud CUNHA, p.189): "One of these Authors (the Fellow that was pilloryed, I have forgot his name) is indeed so grave, sententious, dogmatical a Rogue, that there is no enduring him" ("Um desses autores [o Camarada que esteve no pelourinho, esqueci seu nome] é, na verdade, tão grave, sentencioso e dogmático quanto um mentiroso, que não é possível suportá-lo”). Essa rejeição remete-nos a Maingueneau, quando afirma que "Para que a paratopia seja completa, para não se encerrar em nenhum estatuto, é preciso ser o excluído dos escritores, aquele que contesta a própria paratopia institucional da literatura".

\footnotetext{
${ }^{11}$ Os títulos e traduções foram retirados de WATT, I. Mitos do individualismo moderno. Rio de Janeiro: Jorge Zahar Editor, 1997.
} 
Defoe foi um homem das letras cujos discursos dirigiam-se a um público pouco sofisticado na arte de ler. Fernando Savater (2001, p.217) coloca os seus leitores como a "gente da rua, a massa burguesa e popular [...], a plebe ávida de emoções, fantasmas, viagens aventureiras [...]" e afirma que Defoe, antes de escrever a obra, procurou um editor popular que se interessou por seu projeto. Robinson, nome popular, juntou-se a Crusoé, sobrenome de um colega de classe de Defoe, o que Savater considera facilitar a identificação pela similaridade final dos nomes. Segundo Bakhtin, ser escritor, na Idade Moderna, era uma das várias formas profissionais de autoria.

Autor de singulares aventuras de um marinheiro, Daniel Defoe recusava a nomeação de sua obra como romance, visto a conotação negativa do gênero. Com efeito, o desprestígio do romance era tal que Thomas Beddoes, proeminente médico de Bristol que atuava no fim do século XVIII, considerava que a masturbação, causa de doenças nervosas, era incentivada pela leitura dos romances que aumentavam a indolência, o mundo imaginário "incapacitando aqueles, que o habitam em pensamento, de sair para o mundo real" (POTTER, 1993, p.368). Sedentários, adolescentes da alta sociedade refestelavam-se em sofás, lendo romances lascivos. O médico também considerava que o onanismo era causado ou exacerbado pelo poder da linguagem. Swift, que ironizou Defoe, também foi contemplado por Beddoes, que considerava a demência senil do autor de "As viagens de Gulliver" produto de sua “própria mão”, causa que os críticos literários não conseguiram perceber...

O mesmo sentimento aplicava-se à leitura feminina dos romances, como mostra o quadro de Pierre-Antoine Baudoin, "A leitura". 


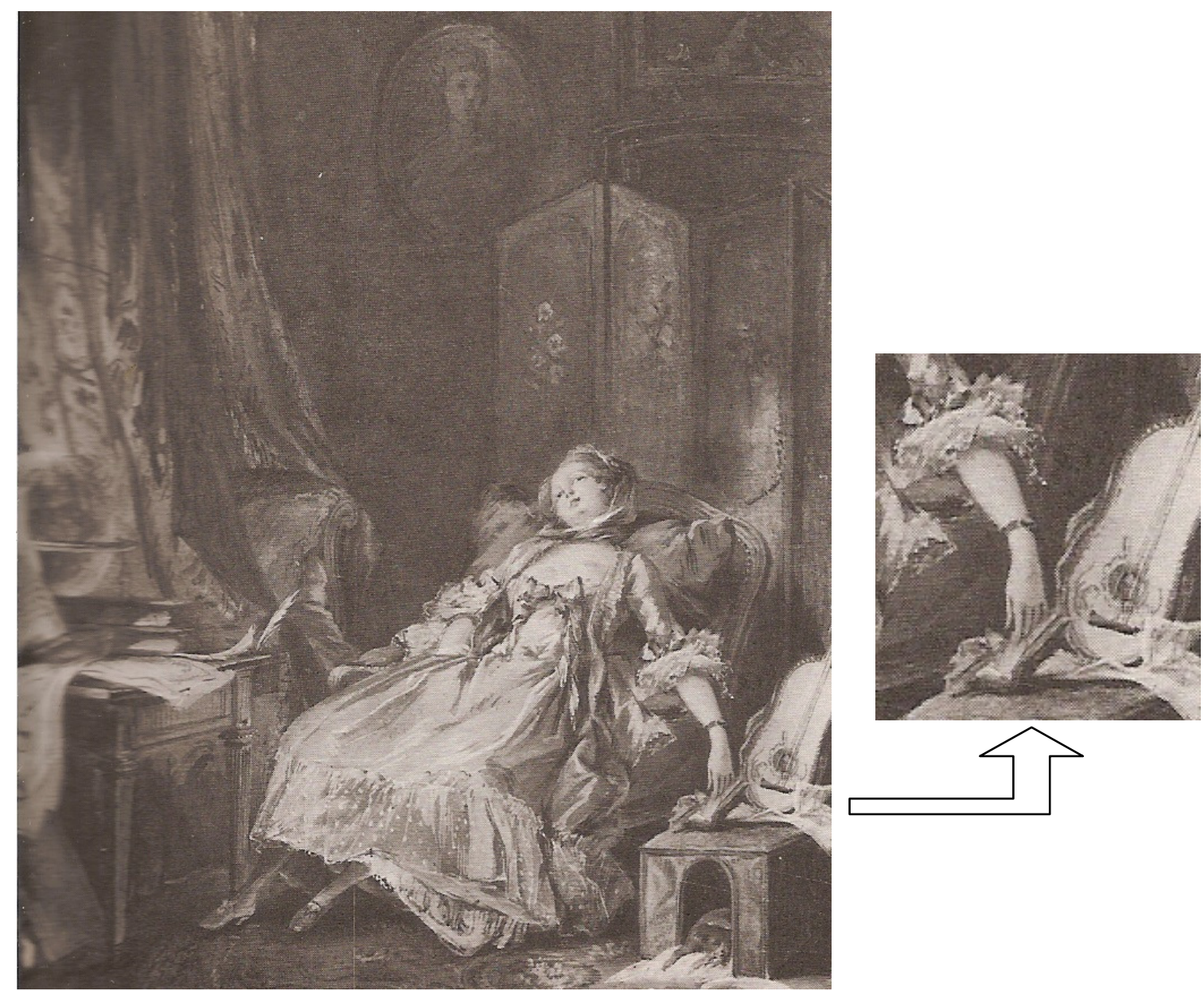

Figura 2: Quadro: A leitura (Pierre-Antoine Baudoin - 1723-1769). No destaque, o romance.

Em Pierre-Antoine Baudoin, um interior confortável, macio, protegido pela porta fechada e pelo biombo aberto [...] à direita [...] o romance que perturbou a leitora, entregue a suas imaginações sensuais. O pintor joga com dois planos: um, moral, que previne contra as seduções das leituras demasiado galantes; o outro, lascivo, que viola a intimidade da jovem sonhadora (Paris, Museu de Artes Decorativas) ${ }^{12}$.

Se Defoe já ocupara posição de destaque na veiculação de discursos pela instância do jornalismo, a escrita de Robinson Crusoé, apesar das críticas ao uso da linguagem, colocou-o, em sua maturidade, como um nome inesquecível no campo literário.

Se Defoe/Robinson formam uma unidade, ambos inserem-se no grande tempo, ou seja, "vivem nos séculos, dissolvem as fronteiras da sua época" (BAKHTIN, 2003). Estão entrelaçados a tal trama de enunciados que, talvez, seja impossível perseguir todos os fios que a produzem: pessoas das mais variadas classes sociais e contextos históricos, vinculadas ou não às questões do livro, leitura e literatura.

\footnotetext{
${ }^{12}$ BAUDOIN, P-A. A leitura. Reprodução de obra de arte. Paris, Museu de Artes Decorativas. In: CHARTIER, R. (org.). História da Vida Privada. São Paulo: Companhia das Letras, 1992, p.147.
} 


\section{ALGUNS FIOS DA CADEIA DISCURSIVA}

Tentar reunir tudo o que já se falou sobre a obra "Robinson Crusoé" é uma empreitada impossível, mesmo em tempos de internet. À digitação, no Google, do nome em português e inglês - Robinson Crusoé e Robinson Crusoe - obtêm-se os seguintes resultados (acesso em 16 maio 2009):

\begin{tabular}{|l|l|}
\hline Apresentação /palavras complementares & Resultados \\
\hline filme & 582.000 \\
\hline resumo & 2.730 .000 \\
\hline livro & 88.100 \\
\hline Daniel Defoe & 717.000 \\
\hline download & 346.000 \\
\hline a conquista do mundo numa ilha & 4.390 \\
\hline biografia & 22.300 \\
\hline filme download & 22.900 \\
\hline resenha & 1.950 \\
\hline resumo do livro & 18.700 \\
\hline island & 396.00 \\
\hline game & 724.000 \\
\hline on sin island torrent & 17.800 \\
\hline on mars & 68.500 \\
\hline
\end{tabular}

Quadro 1: Resultados de busca pelo nome do personagem no Google (port/ing).

"Navega-se" muito. A persistência exige paciência e seleção cuidadosas de materiais. Dentre as várias coletas, seleciono a pesquisa feita em uma biblioteca virtual dirigida a estudantes e educadores, a Questia School ${ }^{13}$ (acesso em 28 fev. 2009), que revelou 2.306 resultados para a chamada "Robinson Crusoé", assim distribuídos: 1479 referências em livros; 354 em artigos de jornais; 117 em artigos de magazines; 346 em jornais diários; e 10 em artigos de enciclopédias. Outros endereços de interesse são: a Defoe's Review ${ }^{14}$, a

\footnotetext{
${ }^{13} \mathrm{http}: / / \mathrm{www} . q u e s t i a s c h o o l . c o m / I n d e x . j s p$

${ }^{14} \mathrm{http}: / /$ defoeereview.org/
} 
Luminarium $^{15}$ - uma antologia de Literatura Inglesa com farto material sobre Defoe, a Enciclopédia Cambridge de História da Literatura Inglesa e Americana ${ }^{16}$, e a Romanic Review $^{17}$, publicação acadêmica da Universidade de Columbia dedicada ao estudo e à crítica literária. A Biblioteca Lilly, da Universidade de Indiana ${ }^{18}$ (Bloomington), apresenta uma rica coleção de informações sobre os trabalhos de Daniel Defoe. Sobre Robinson Crusoé há imagens de suas primeiras publicações, traduções e edições infantis ${ }^{19}$. Também revelou-se bastante promissora a pesquisa no catálogo da Biblioteca da Universidade McMaster $^{20}$, no Canadá; à digitação de "Daniel Defoe", encontramos 1946 itens e, para "Robinson Crusoe", 232 (acesso em 09 jul. 2009).

A enumeração de nomes importantes da cultura que se referiram à obra de Robinson Crusoé cria outra imensa lista. Quer sejam teóricos da cultura, escritores ou críticos literários, a abordagem da obra abre-se para inúmeras vertentes.

Uma dessas vertentes considera Robinson Crusoé um protótipo do homem econômico. Sua ação enfatiza o poder individual do homem e seu sucesso na dominação da natureza.

Analisando a obra de Defoe, em seu livro "Mitos do individualismo moderno", o professor Ian Watt (1997) coloca em discussão essa postura. O autor concorda com o fato de Robinson viver em função de, ou até mesmo ser governado por um motivo econômico. Ele diz (p.162): "Sua sensibilidade está conectada às coisas materiais: ele é metódico, trabalhador, e sabe como fazer uma acurada avaliação de resultados", mas relativiza essa posição ${ }^{21}$, ao afirmar: "Não se pode, é claro, ver Crusoe apenas como aquele tipo ideal, o homo economicus, pois de fato ele chega a inventar algumas pequenas diversões e entretenimentos que fazem o tempo fluir mais agradavelmente na ilha". E o autor cita a criação dos animais e o trabalho de ensinar um papagaio a falar como tais atividades. Por isso, Watt coloca Robinson ocupando uma posição entre o homo economicus e o "homem-comum", entendendo esse último aspecto como o ponto de interesse de alguns críticos, como Samuel Taylor Coleridge, o qual considerou Robinson um representante da humanidade como um todo, pois todos os homens veem-se em suas ações, pensamentos, sentimentos e desejos.

\footnotetext{
${ }^{15} \mathrm{http}: / / \mathrm{www}$. luminarium.org/

${ }^{16} \mathrm{http} / / / \mathrm{www} \cdot$ bartleby.com/cambridge/

${ }^{17} \mathrm{http} / / / \mathrm{www}$. columbia.edu/cu/french/romanicreview/

${ }^{18} \mathrm{http}: / / \mathrm{www}$. indiana.edu/ liblilly/defoe/index.html

${ }^{19}$ Ver Anexo B.

${ }^{20}$ http://www.mcmaster.ca/

${ }^{21}$ Ibidem, p. 160.
} 
Outra vertente de interpretação da obra coloca em foco seu aspecto religioso. Ian Watt também a discute, citando como representativos dela os estudos de George Starr e J. Paul Hunter.

Segundo Watt, Starr analisa a narrativa de Robinson do ponto de vista do pecado, do arrependimento e da regeneração ligada ao puritanismo, do qual Defoe era seguidor e cuja presença pode ser constatada em toda a obra desse escritor do século XVIII. Hunter, por seu turno, aceitando esse pressuposto, mostra um Defoe com fé na Providência, mas diz que, junto com ela, o escritor "confiava na literatura-providência, em medida que supunha capaz de ser notada pelos seus contemporâneos"22.

A posição de Watt a respeito do individualismo religioso de Robinson é considerar a importância de sua análise, mas ele vê a prática religiosa do náufrago como uma "religião dominical", afirmação que foi muito combatida por seus críticos, conforme ele mesmo declara. Watt entende que, ao estudar essa abordagem, é preciso lembrar o processo de secularização pelo qual passava o pensamento na época de Defoe. Sem poder negar a importância da Providência divina presente na obra, o autor lembra que Defoe tinha uma história para contar e vender, e cita R. H. Tawney a respeito do puritanismo: “ "uma característica do puritanismo' era 'enfatizar fortemente a vida das empresas comerciais como o campo mais apropriado para a diligência do cristão; essas qualidades, e a admiração por elas, permaneceram, mesmo quando a referência religiosa e as restrições por ela impostas enfraqueceram e desapareceram, "23. Analisando momentos de religiosidade do homem solitário, Watt pontua alguns aspectos. Um deles é a incoerência que se manifesta quando o jovem diz que só rezou verdadeiramente no momento de sua doença, em contraposição a falas anteriores que mencionam oração sincera em momento anterior ao naufrágio e agradecimento pela salvação. Watt pergunta-se o quanto havia de pensamento religioso no escrito de Defoe, dadas algumas informações sobre o escritor.

Transcrevemos o excerto esclarecedor de $\mathrm{Watt}^{24}$ :

Sabe-se que Defoe era muito dado a alterar aquilo que escrevia. O anônimo livreiro que publicou a segunda edição de Complete English Tradesman escreveu: 'para conseguir uma cópia vinda de sua própria pena, e escrita à sua maneira habitual, era necessário pagar-lhe um tanto por folha; e, depois, mais a metade desse tanto para que podasse as excrescências ou resumisse' o texto. Portanto é possível concluir, com boa margem de segurança, que Defoe operava seu pensamento mediante algumas afirmações exageradas,

\footnotetext{
${ }^{22}$ Ibidem, p. 163.

${ }^{23}$ Ibidem, p. 168.

${ }^{24}$ Ibidem, p. 166.
} 
que às vezes talvez fossem inconscientemente lançadas com esse formato justamente para serem atenuadas por outras afirmações e atos de conduta.

Outro ponto abordado por Watt é que Robinson não tenta converter à sua religião o pai de Sexta-Feira e nem espanhóis que chegam à ilha posteriormente, tal como fizera com o "selvagem" que se tornou seu fiel servidor; e nem agradece a Deus ao sair da ilha, desaparecendo, a partir de então, as alusões a aspectos religiosos.

Pelos dados expostos, Ian Watt reafirma sua posição de que Robinson praticava uma religião dominical, sem ser um dissidente e nem um típico puritano. Sua religião é individualista, não tem pretensão de amar o próximo.

É sabido que a obra "Robinson Crusoé" foi vista pelo filósofo Jean Jacques Rousseau como um verdadeiro tratado de educação natural. A partir da leitura de Watt, levantamos os seguintes dados: em sua obra "Os devaneios de um caminhante solitário", Rousseau cita a criação de Defoe seis vezes, mas é em "Emílio" que se faz sentir mais fortemente a importância que o filósofo tributava a ela. Apoiados em Watt, transcrevemos partes do excerto encontrado:

Em sua ilha, sozinho, sem contar com a ajuda de companheiros nem de
instrumentos necessários às diversas artes, ele consegue assegurar a própria
sobrevivência, a própria segurança, chegando mesmo a alcançar um certo
bem-estar, assunto que certamente interessa a todas as idades, e que
podemos de mil maneiras tornar agradável às crianças. [...] O melhor meio
de nos livrarmos dos preconceitos, e de organizar o nosso pensamento em
sua verdadeira relação com as coisas, é nos vermos como se estivéssemos na
situação de um homem isolado, e julgar tudo da maneira como ele poderia
julgar, ou seja, conforme a utilidade das coisas para ele (ROUSSEAU apud
WATT, 1997, p.179).

Para Watt, Rousseau considerava que a solidão possibilitava o julgamento da utilidade das coisas. Além disso, ela eliminava a existência de competidores, atendendo a objetivos educacionais pregados pelo autor. Ian Watt diz, ainda, que a visão rousseauriana é uma traição à de Defoe por questões de tradução da obra para o francês. E exemplifica com o uso do termo "natural". Considerando a versão francesa mais formal, Watt diz que a invocação da natureza aí induz de modo mais veemente a uma atitude de adoração que não se encontra no original inglês, mais afeito à ideia de aproveitamento. Além disso, o crítico afirma que o filósofo não se interessava pelo laisser faire econômico, mas sim "pela psicologia do laissez-moire faire, vivida em cenário natural, destinado a priori a ser belo por si mesmo",25.

\footnotetext{
${ }^{25}$ Ibidem, p. 181 .
} 
Podemos acrescentar que, como romântico, Rousseau valorizou o individualismo.

Colocamos em questão se, realmente, é o caso de se considerar a leitura de Rousseau uma traição pelos fatores apontados por Watt. O fato de ler uma obra traduzida implica interferências na leitura que ficam a cargo de outras instâncias, que não a do leitor.

No campo das ideias econômicas também Robinson foi levado a fazer incursões, fornecendo a Karl Marx elementos de análise e formulação de críticas a trabalhos de outros economistas que não apoiavam seus estudos em textos originais de Defoe. É também Watt quem nos oferece os elementos de reflexão.

Segundo o crítico, Marx comenta Robinson Crusoé em duas obras juvenis - "The Poverty of Philosophy" e "Grundisse". Robinson não é tomado como um verdadeiro representante do processo de produção, visto este ter natureza social e não individual. As relações que o náufrago estabelece com as coisas mostram, segundo Marx, o que é essencial para a determinação do valor - ele conhece seus objetos de uso, as operações necessárias à produção e o tempo de trabalho investido (PRAWER apud WATT, 1997, p.184).

Ian Watt reconhece a importância de Rousseau e de Marx para a internacionalização do mito de Robinson. Mas chama-nos a atenção o trecho que se segue e, sobre o qual gostaríamos de fazer algumas considerações ${ }^{26}$ :

Rousseau admirava Robinson Crusoe por motivos errados - ou pelo menos não em conformidade com os propósitos de Defoe -, favorecendo assim as idéias que tinha sobre si mesmo e a natureza do eu em geral. Marx também favorecia Crusoe a partir de seu próprio ponto de vista, que era muito diferente; e, como tal, seria decerto igualmente desconcertante para Defoe. Mas tanto Rousseau quanto Marx desempenharam um papel essencial, o de garantir, no século XIX, a continuação da popularidade de Crusoe como figura mítica. A solidão romântica tornou-se popular; o mundo natural, o lugar adequado para vivenciá-la; a virtude do trabalho sob o controle do indivíduo livre passou a ser um ideal aceito pela sociedade. A apropriação de Crusoe com propósitos ideológicos diferentes - e às vezes realmente contraditórios - contribuiu para a forma que o mito de Crusoe, e o mito do individualismo em geral, iria tomar nos séculos XIX e XX.

As observações de Watt sobre a leitura de Robinson por Rousseau e Marx apresentam um caráter avaliativo e prescritivo de um único sentido, o formulado pelo autor; não abrem para o conceito de leitura como ato plurissignificativo, mesmo dentro de limites impostos pelo texto. Além disso, consideramos importante diferenciar a leitura que é orientada por um determinado propósito ideológico, daquela que, sempre, e necessariamente,

\footnotetext{
${ }^{26}$ Ibidem, p. 184.
} 
do nosso ponto de vista, é eivada de valores ideológicos, de natureza social e, muitas vezes, inconscientes. Qualquer leitor está imerso em ideologias, a palavra, por si, é ideológica.

Watt discute posturas assumidas sobre Robinson Crusoé. Mas qual é a sua posição pessoal?

Os estudos de Ian Watt reservam a Robinson o lugar de um mito do individualismo moderno. Por que um mito, se não é um personagem sagrado, atuando em favor de uma coletividade, nem deus ou semideus? O autor adverte que Robinson é um mito $\underline{\text { moderno, }}$ pois traz em si a contradição indivíduo e sociedade. Sua solidão é forma de expressão do individualismo.

A ilha de Robinson é a utopia de um homem de negócios. A moral da obra é a dignidade do trabalho porque ela oferece um modelo pelo qual os processos econômicos básicos são transformados em atividades lúdicas. No entender de Watt, os objetivos do rapaz estão no horizonte dos instintos naturais e ele não apresenta exigências emocionais de níveis mais elevados. Em suas relações com outras pessoas, trata-as como mercadorias ou as faz trabalhar para atender a seus interesses pessoais. No que se refere ao uso da linguagem, o autor considera que Robinson faz dela um uso utilitarista, pois ensina o "Sim" e o "Não" a Sexta-Feira. Quanto a este último aspecto, mesmo sem entrarmos nas relações de linguagem entre Robinson e Sexta-Feira, traremos, neste trabalho, uma visão dialógica do uso da linguagem na Ilha do Desespero.

Watt conclui (1997, p.176):

[...] para bem ou para mal, Robinson Crusoe é o épico dos que não desanimam. E é uma obra em que não há lugar para a expressão do coletivo; uma obra na maior parte dedicada ao egocentrismo imune à crítica; uma obra sobre alguém capaz de florescer magnificamente em uma ilha deserta.

No cerne de sua conclusão, o autor afirma “[...] uma obra em que não há lugar para a expressão do coletivo [...]". Será mesmo?

Embora a condição de solidão do personagem aflore com muita força, há autores que focalizam o caráter social da obra. Em edição datada de 1940, da Série Clássica de "Cultura" - "Os Mestres do Pensamento", sob a direção de José Pérez (com tradução portuguesa revista e atualizada por Nabor Cayres de Britto), o editor apresenta um olhar diferenciado em relação aos que enfatizam a solidão do personagem. Diz ele (no prefácio):

Sabes, desocupado lector - como te sauda, com eterna graça, o divino Cervantes, no pórtico majestoso do seu Prólogo ao primeiro Quixote sabes qual é, a meu parecer, o valor permanente de Robinson, a 
maravilhosa novela do homem solitário? Pois nada mais, nada menos, do que um estupendo valor social.

Paradoxo? Tése estravagante, a minha?De nenhum modo. Vais verificar, consolidada em argumentos, corroborada em razões, a validade da assertiva.

Demonstrarei com o romance imortal de Daniel Defoe, a primeira de todas as leis sociologicas, enunciada, com suma claridade espiritual, por Spinoza: "Nada mais útil para o homem do que o proprio homem..." (Homini igitur nihil homine utilius...” (Ética, Prop., XVIII, Esc.).

Perez vale-se da tese hegeliana de que a negação leva em si a afirmação e prova-a, ou seja, a solidão traz, em si, o social, em se tratando de um homem já em estado de sociedade e não de um selvagem. Conclui que a solidão é relativa e cita uma frase de André Therieut: “Uma vez que alguém se põe a compreender a canção das coisas, não há mais solidão. Ha, sómente, a doçura de estar só”. E diz (prefácio):

Do ponto de vista, digamos físico, isto é, da falta de contactos ou intercomunicações, intercomerciais ou intercâmbios de fala e reações sociais recíprocas, ainda é possível admitir-se uma solidão integral.

(Seria Robinson, no caso). Mas do ponto de vista psicológico, moral e intelectual, pelos reflexos perfeitamente apreciaveis sôbre as ações dos chamados solitários, a solidão é ilusória, aparente [...].

O autor defende a ideia de que nunca se está só verdadeiramente, pois o pensamento é um produto social - "O pensamento - fenómeno que parece produto da sociedade - funciona como um conduto intercomunicante com a própria sociedade [...] alimentando-se dela, que nêle se embebe [...]” (p.4). E sustenta-se com os versos de Lope de Vega:

\footnotetext{
A mis soledades voy

De mis soledades vengo,

Porque para andar comigo

Me bastam mis pensamientos.
}

Considerando a sinergia da vida, porém, Perez destaca a imposição da espécie, citando Kant, "Só o par é completo" (prefácio), e a Bíblia (Eclesiástico), "Melhor é estarem dois juntos do que um só" (IV 9) (prefácio). O autor considera grandiosa a solidão de Robinson, mas, maior do que ela é o pensamento do personagem que conjectura sobre a sociedade, criticando-a. O aparecimento de Sexta-Feira fortalece o jovem e, novamente, Perez retoma a tese de que "Nada mais útil para o homem do que o próprio homem [...]".

O filósofo Fernando Savater também compartilha de uma visão social da obra de Defoe. Ele afirma em seu livro “A Infância Recuperada” (2001, p.220, 221): 
Alguns acreditam ver nessa novela algo assim como uma parábola destinada a provar que o indivíduo humano pode se virar sozinho, fora da sociedade. Nada mais errado: Robinson Crusoé é precisamente um canto ao necessariamente social de nossa condição [...].

O autor afirma que, mesmo numa ilha deserta, o nosso vínculo com a sociedade permanece pela memória, que conserva "os modelos da técnica, os procedimentos para realizá-los [...] e também os vestígios das rotinas que os reclamam" ${ }^{27}$. Robinson reinventa a civilização e não retorna como selvagem, diferentemente do que parece ter acontecido com Alexandre Selkirk, conforme afirma o filósofo espanhol.

Concordamos com Savater ao ressaltar a importância da memória, mas enfocamos, em nossas considerações, a memória como o testemunho da experiência, o uso da palavra que narra e ancora-se na vida vivida.

Foram as condições de solidão e ausência de convívio humano de Robinson Crusoé que remeteram o semiólogo Roland Barthes a incorporar essa obra em seu corpus de pesquisa sobre a idiorritmia (ao lado de Gide: "La sequestrée de Poitiers"; Paládio: "Histoire lausiaque"; Thomas Mann: "La montagne magique"; Zola: "Pot-Bouille"). Idiorritmia, segundo consta no prefácio de "Como viver junto" (BARTHES, 2003), escrito por Claude Coste, “designa [...], no curso de Barthes, todos os empreendimentos que conciliam ou tentam conciliar a vida coletiva e a vida individual, a independência do sujeito e a sociabilidade do grupo". Em "Como viver junto", Barthes elenca os motivos da escolha da obra de Defoe em um tema que, aparentemente, não o contempla (2003, p.28-29):

[...] interessa o Viver-Junto não apenas como termo opositivo (a solidão), mas também porque Robinson enfrenta um problema de adaptação análogo ao do Viver-Junto: objetos, natureza $=$ sujeitos humanos. [...] enfim, curiosa tautologia: esta epopéia da solidão é designada, miticamente, como o romance feito exemplarmente para vivificar a solidão.

Em nota de rodapé, Barthes informa que, na obra de André Malraux, "Oeuvres complètes", François Ledoux, em seu prefácio, alude à "Les noyers de l'Altenburg" dizendo (apud BARTHES, 2003, p.29):

E em nossos dias, André Malraux fará um de seus personagens dizer que, para quem viu as prisões e os campos de concentração, somente três livros conservam sua verdade: Robinson Crusoé, Dom Quixote e O Idiota.

Sem entrarmos em todas as considerações que Barthes faz acerca de Robinson no que se refere à idiorritmia, vamos tomar apenas duas colocações como referência:

\footnotetext{
${ }^{27}$ Ibidem, p.221.
} 
"Experiência-limite" e "O desejo do dois", lembrando que a escrita barthesiana acontece por fragmentos, em ordem alfabética.

No que se refere ao primeiro aspecto, Barthes diz que rituais de clausura podem levar a experiências-limite e que Robinson Crusoé, "sujeito 'sadio', 'racional', 'empírico' como poucos" adotou "condutas de proteção ilimitadas" ao sentir-se em perigo quando viu marcas de passos na areia. Seus atos de construir uma "paliçada-muralha" camuflada de mato, fazer uso de escada removível e não de portas mostram a busca de uma proteção absoluta, o que é uma "miragem". Diz ele que "Sair é desproteger-se: a própria vida" (2003, p.117).

Quanto ao "Desejo do Dois", o semiólogo francês escreve (2003, p.183):

[...] o Um é notado como uma punição. Condenado a ser apenas Um, é ser punido por alguma razão. Robinson exprime constantemente essa crença: que estando condenado a viver só numa ilha deserta, está pagando os erros de sua juventude, principalmente a rebelião contra seu pai, que o havia proibido de embarcar. Depois do naufrágio, quando ele faz o balanço de sua situação, faz explodir o desejo do Dois: 'Oh! Que um homem tenha sido salvo! Oh! Que um único homem tenha sido salvo! E, em seguida, o episódio da descoberta do rastro de passos humanos: tudo é desde então articulado pelo suspense da descoberta de outro homem. O que será enunciado assim, e que vale para qualquer um de nós: Dois é o suspense de Um (e Um é prenhe de Dois).

Ao retomar Perez, lembrando Kant - "Só o par é completo"; o Eclesiástico "Melhor é estarem dois juntos do que um só"; e a menção de Barthes - "Dois é o suspense de Um (e Um é prenhe de Dois)", entendemos que o primeiro autor traz um enfoque de completude dos gêneros da espécie e expressa uma visão dialética e o segundo, validando seu enunciado para todo ser humano, sinaliza ritmo e alternância, busca de conciliação entre solidão e vida social.

Barthes considera que o encanto da obra de Defoe, para ele, é o "nãoacontecimento", ou seja, os fatos que ocorrem na vida de Robinson - como as lutas com os selvagens, canibais (faz exceção ao episódio de Sexta-Feira) - quebram a possibilidade de fantasiar sobre "a organização doméstica da vida, a choupana, o jardim das uvas, o bucolismo", perturbando seu prazer de leitor ${ }^{28}$.

$\mathrm{O}$ personagem tanto o encantou que o autor imaginou escrever um novo Robinson Crusoé, colocando-o em um isolamento linguístico dentro de uma metrópole. Sua proposta pouco usual, posto não ter sido realizada, foi discutida por Nicole Bracker em um artigo da "Romanic Review" (jan-mar, 2000), intitulado "Robinson Crusoé a venir: Gertrude Stein and

\footnotetext{
${ }^{28}$ Ibidem, p. 165 .
} 
Roland Barthes"29. A autora trabalha com a visão desses dois importantes nomes: a escritora Gertrude Stein e Barthes, em suas relações com a obra de Defoe.

Barthes, segundo Bracker, demonstra diferentes razões para ser seduzido por Crusoé. Uma delas refere-se à própria condição da arte e da linguagem - ter um significado profundo, sempre perseguido, mas nunca alcançado. Nessa perspectiva, Robinson não apresenta uma sequência de eventos, mas um leque de possibilidades para a criação de novas histórias, pois é no vazio da linguagem que se constitui a escrita. Outra razão apontada é a forma autobiográfica da obra, lembrando que Barthes fez sua autobiografia, na qual procura ver-se como um "outro", como um “objeto descritível e não como objeto introspectivo". Daí derivaria a ideia de colocar Robinson em um exílio linguístico - a autobiografia sendo o espaço vazio no qual se constrói o discurso da subjetividade e da individualidade. A famosa marca da pegada traz, ao autor, a ausência como presença, condição que ele também imputa às Sereias da Odisseia. Sendo falsa no campo da percepção e verdadeira em termos de tempo, a marca do pé na areia reveste-se de uma condição de "loucura" semelhante à da enunciação, em que há uma simultânea ausência e presença.

Caminhando com Stein, Bracker fala-nos no desejo da autora de ficar num isolamento linguístico, de ficar só, com seus pensamentos e sua própria língua, sem ser compreendida por ninguém. Este fato aponta uma divisão entre um mundo com o qual ela conversa e um mundo sobre o qual pensa, mostrando o desafio de a individualidade manter-se no interior da sociedade. Além disso, a solidão é condição essencial para o trabalho de criação artística e intelectual, conduzindo o autor a um labirinto. Bracker cita Valery a respeito do trabalho do escritor, comparando-o a um Robinson intelectual. Em sua obra "Autobiografia de Alice B. Toklas", Stein termina o texto com referência a Defoe: "You know what I am going to do. I am going to write it for you. I am going to write it as simply as Defoe did the autobiography of Robinson Crusoe. And she has and this is it" (em tradução livre, "Você conhece a minha intenção. Estou escrevendo para você. Tão simplesmente quanto Defoe fez a autobiografia de Robinson Crusoé. Ela a tem, e aí está”).

Em suas considerações, Nicole Bracker também faz referências a um pensador francês, Michel de Certeau, e encerra seu artigo alinhando-se com Barthes na tentativa de “evitar a palavra final” - ela diz que não pode haver a palavra final na história de Robinson Crusoé.

\footnotetext{
${ }^{29}$ Disponível no endereço eletrônico: http://findarticles.com/p/articles/mi qa 3806/is 200001/ai n8881003.
} 
Michel de Certeau considera a obra de Defoe o romance da escritura, apontando um paralelismo entre a escrita de Robinson no papel e a conquista e colonização da ilha, também consideradas atos de escrita. Encaminhadas as providências para dar conta das primeiras necessidades, a escrita do diário configurou-se, para Robinson, como a apropriação do tempo e do espaço, numa relação estreita com as ações de cunho capitalista. Certeau considera que, assim como a página em branco é um espaço "próprio" onde um sujeito constrói um texto, a ilha onde Robinson produziu também configura-se como um espaço de escrita, grafado pelos passos e ações do personagem. Caminha-se na ilha e no papel. O texto construído tem em vista uma eficácia social, ou seja, busca mudar uma realidade. São palavras do autor (1994, p.226): “[...] a empresa escriturística transforma ou conserva dentro de si aquilo que recebe do seu meio circunstancial e cria dentro de si os instrumentos de uma apropriação do espaço exterior". Na escrita de Robinson vai se imprimir a marca de uma ausência, um pé humano que, contudo, não se escreve, não tem lugar, não tem texto próprio e é perturbador - nomear, falar do selvagem cria o que se acha fora do escrito. É por isso que Certeau diz ${ }^{30}$ : “A 'ficção teórica' inventada por Daniel Defoe esboça assim uma forma de alteridade relativa à escritura [...]”. No campo do escrito o pé descalço corresponde à citação. O autor liga Robinson Crusoé a um deslocamento histórico do problema da enunciação e considera o romance um mito da sociedade escriturística moderna.

Como forma possível de interpretação do mito, temos a leitura psicanalítica, em que significados simbólicos são transferidos para processos análogos da vida inconsciente do homem. Nessa linha, foi feita a leitura de Robinson Crusoé por Marthe Robert, explicada em seu livro "Romance das Origens, origens do Romance," com primeira edição francesa em 1972 e portuguesa (Lisboa) em 1979.

A autora entende que o imaginário do gênero romance alimenta-se de um padrão narrativo arcaico que a criança constrói quando vive sua primeira decepção com o idílio familiar. Do paraíso idealizado ao estranhamento, a criança sente-se perdida e abandonada; com a descoberta da sexualidade, ela passa a atribuir-se um nascimento ilegítimo e inclui, na construção de sua história, a ideia do bastardo. Será preciso que essa "Criança Perdida" aprenda a ver o mundo em sua realidade. Dentro dessa perspectiva, Robinson Crusoé faz uma viagem regressiva em que o naufrágio é uma vitória sobre a morte e um renascimento "no qual a angústia do abandono é incessantemente embalada pela embriaguez do recomeço" (ROBERT, 2007, p.103). O mar tem o papel de uma mãe carnal - rejeitou-o e deu-lhe a

\footnotetext{
${ }^{30}$ Ibidem, p. 249 .
} 
possibilidade de reinar sozinho em uma ilha, pelo afogamento de outros homens que poderiam lhe cercear o poder. Robinson, na chegada à ilha, é a "Criança Perdida", um recémnascido. Acha-se nu, confiscado de uma existência anterior, depurado de pecados e próximo do estado adâmico perfeito ${ }^{31}$. Robert entende que a primeira parte do romance trata da reeducação que vai levar o herói à superação de seu infantilismo. Somente nessa nova condição é que ele poderá tornar-se rei, pai e senhor, momento em que surge a figura de um novo habitante na ilha. Sobre o uso da linguagem, vejamos o que diz a autora ${ }^{32}$ :

[...] Robinson vive em perfeita harmonia com os animais inocentes, que, como no sonho, no conto ou no mito, apegam-se a ele para o ajudar, distrair e fielmente servir. Se por um lado esta é a parte idílica de sua reclusão ambígua, por outro ele não deixa de sofrer com o silêncio de seus animais, sendo ainda bastante cativo do intelecto para compreender a linguagem muda (o silêncio é o único defeito de seu Paraíso, e ele trata de remediá-lo falando sozinho e, naturalmente, mantendo regularmente seu "Diário"); mas, se a nostalgia da linguagem o leva a expedientes algo pueris (ensina o papagaio a falar e fica desolado por não conseguir instruir analogamente o cão), nem por isso ele deixa de conhecer, junto aos animais, a graça de uma vida imediata que, na medida mesma em que prescinde de palavras, está isenta de erros e mentiras, ao abrigo de questões e juízos que são em toda parte fonte de sofrimento.

Sem entrar na discussão do arcabouço teórico organicamente constituído e adotado pela autora, gostaríamos de colocar em questão dois aspectos acima apontados: o fato de considerar que a vida de Robinson prescindia de palavras e o de que sua nostalgia de linguagem o conduzia a ações pueris. Em nossa perspectiva de estudo, que será explicitada no decorrer deste trabalho, a vida de Robinson era plena de linguagem e sua busca de interlocutores revela o papel essencial do Outro no uso da palavra.

$\mathrm{Na}$ análise do romance, a autora faz coro a Defoe, no sentido de identificar a obra como verdadeira, afirmando que ele coloca o trabalho na terra do sonho, mostra uma condição burguesa de desenraizamento social, prosperidade econômica, audácia e confiança nos próprios méritos do homem. E, neste sentido, Robert (2007, p.108) diz que "o romance burguês persegue conscientemente seus objetivos em perfeita consonância com os planos do eterno retorno infantil". Para ela, Robinson Crusoé é um livro eminentemente fundador, impulsionador do romance na busca de espaços desconhecidos, com influência no âmago de sua criação, "na medida em que, rebaixado precocemente ao nível de literatura para crianças, tornou-se o guia e instrutor dos futuros romancistas" ${ }^{, 3}$. Sobre esta última citação da autora,

\footnotetext{
${ }^{31}$ Ibidem, p.104.

${ }^{32}$ Ibidem, p. 112.

${ }^{33}$ Ibidem, p. 125.
} 
entendemos que a adaptação da obra de Defoe para crianças e jovens não representa, por si mesma, um rebaixamento da criação; a literatura infantil e juvenil tem uma força que ainda precisa ser melhor conhecida e posta a favor de seu público.

Protótipo do homem; para alguns, do homem inglês, heroico, corajoso, pleno de recursos. O escritor James Joyce (1912 apud WATT, 1997, p.176) disse, em conferência sobre Defoe: “O espírito anglo-saxão está por inteiro em Robinson Crusoé: a independência varonil; a crueldade inconsciente; a persistência; a inteligência lenta, mas eficiente; a apatia sexual; a religiosidade equilibrada e prática; a reserva calculada". Joyce considera Robinson o Ulisses inglês. Na verdade, Robinson Crusoé transcende fronteiras culturais, o que o reforça como mito (na França, por exemplo, sua figura ligou-se aos ideais da Revolução de 1789).

Outros renomados escritores referem-se a Robinson Crusoé, seja como objeto de reflexões, seja como memória de leitura.

Virgínia Woolf, escrevendo sobre a obra, inicia seu trabalho com uma questão entre as muitas maneiras de abordar este clássico, "qual devemos escolher?". Afastando-se de enfoques consagrados por entender que esclarecimentos adicionais não aumentariam o prazer da leitura, ela tece considerações sobre o caráter de obra-prima de Robinson Crusoé. Considera-a um bom exemplo da dimensão do trabalho do escritor e da relação que ele estabelece com o leitor. Assim, tendo em vista o trinômio Deus-Homem-Natureza, com o qual todo escritor se depara, entende que Defoe manteve-se coerente com seu próprio senso de perspectiva, sua própria forma de ordenar o mundo, contrariando, o tempo todo, a visão de mundo de seus leitores. Se, por princípio, pensarmos em uma ilha no fim do mundo, com os constantes nascer e pôr-do-sol, com um homem "meditando sozinho sobre a natureza da sociedade e os estranhos caminhos da humanidade" (WOOLF, 2007, p.45), somos subvertidos em nossas ideias, pois a Natureza aparecerá, apenas, como doadora de seca e água, o homem como um esforçado animal salva-vidas, e Deus sendo um minúsculo ponto sobre o horizonte. Ainda segundo Woolf, Defoe obriga-nos a renunciar a nossos próprios conceitos e segui-lo em sua caminhada. Seu personagem tem olhos de classe média, astutos, racionais, objetivos e realistas, sem entusiasmos; mas, ao fim da narrativa, as ações mais comuns do cotidiano, como cozinhar, por exemplo, acham-se dignificadas; os objetos construídos tornaram-se belos - sem maiores comentários da parte do autor. A descrição dos fatos é suficiente quando se trata de Defoe, um mestre na arte descritiva. Com a imagem de um pote de argila, Defoe harmoniza um universo.

Mencionar Robinson, porém, não faz parte apenas de estudos e reflexões. Na vida pessoal de escritores, ele parece ter sido obra de referência. 
O escritor português Eça de Queiroz, ao escrever, de Londres, para a condessa de Fialho diz (apud DEFOE, 1952, p.6): “Tenho sido, ultimamente, tão abandonado pelos meus amigos de Lisboa - ou pelo menos, daquéle bairro de Lisboa onde eu mais desejo ter amigos - que, se possuísse uma canôa e um papagaio, podia considerar-me realmente como um Robinson Crusoé, desamparado em sua ilha”.

Apesar de não ter sido escrita para crianças, a obra tornou-se fundamental nos acervos de leitura infantil e juvenil. Quando criança, o poeta brasileiro Carlos Drummond de Andrade encantou-se com as aventuras do jovem náufrago, a ponto de lastimar o término de sua leitura, quando teria que se afastar do herói e de seu companheiro Sexta-Feira. A leitura impregnou-o de tal modo que se tornou modelo de comparação para a história de sua própria vida, presente nos versos de seu poema "Infância" - "Eu não sabia que minha história era mais bonita que a de Robinson Crusoé" (1973, p.53-54). Essa descoberta do "homem/menino" poeta dignifica as duas histórias para além de qualquer análise teórica.

Leitores adultos, leitores infantis apreciaram e ainda apreciam as aventuras de Robinson Crusoé. Mas é possível ouvir falar de Robinson Crusoé ainda no berço, embalado por doces vozes adultas, cantando uma canção de ninar (nursery rhyme):

Poor old Robinson Crusoe!

Poor old Robinson Crusoe!

They made him a coat

Of an old nanny goat;

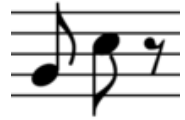

I wonder how they could do so!

With a ring a ting tang,

And a ring a ting tang,

Poor old Robinson Crusoe!

Indubitavelmente, Robinson Crusoé permanece como um texto fundamental desde sua criação até os dias de hoje. Escritores ingleses criaram um subgênero - as robinsonadas. Marthe Robert (2007, p.120) cita que "ainda em 1815, publicava-se na Alemanha uma Bibliothek der Robinsone, em cinco volumes, que se reconhece incompleta". Segundo consta em artigo de Robert Applebaum intitulado "Robinson Crusoé mitos e metamorfoses"34, em 1910 havia-se produzido mais de 500 histórias de ilha deserta, tendo como modelo o náufrago de Defoe. Talvez a mais conhecida seja "A família do Robinson Suíço”, de Johann Rudolf Wys. Fernando Savater fornece a informação de que circula o dito segundo o qual, depois da Bíblia, "Robinson Crusoé" foi a obra mais divulgada da história. Entre suas inúmeras

\footnotetext{
${ }^{34}$ Robinson Crusoe, Miths and Metamorphoses. Utopian Studies. Disponível em:

<http://findarticles.com/p/articles/mi_7051/is_n2_v8/ai_n28700454> Acesso em: 28 fev. 2009.
} 
traduções, encontram-se aquelas para as línguas inuit (povos do Ártico) e copta (estágio final da língua egípcia clássica falada até o século XVII).

A obra "Robinson Crusoé" dialoga com outras obras literárias, tanto anteriores como posteriores a ela. Considerando seu aspecto de colonização e alteridade, podemos inseri-la dentro do tema do imperialismo inglês, com a dicotomia entre o europeu civilizado e o outro, selvagem. Nesse sentido, podemos vê-la em diálogo com "A Tempestade", de Shakespeare (1611). O professor Thomas Bonnici, doutor em Letras pela Universidade Estadual Paulista, crítico literário e tradutor, interessado em estudos pós-coloniais, aponta relações entre a colonização inglesa e a famosa peça shakespeariana; estabelece relações entre a grande reescrita da peça nas últimas três décadas (seu texto é de 2000) e o desenvolvimento de estudos críticos sobre a relação metrópole-colônia. Sugere que "A Tempestade" apresenta indícios de formação de uma ideologia colonialista no Novo Mundo e ação contra indígenas. Mas uma grande obra não se encerra em seu tempo e, dentro da rede interdiscursiva que se tece continuamente, o escritor sul-africano, crítico e tradutor John Maxwell Coetzee, ganhador de Prêmio Nobel de Literatura em 2003, escreveu o romance "Foe". Nessa obra, uma narradora feminina, Susan Barton, leva sua versão da história de Cruso a um autor inglês chamado Foe, para que seja reescrita e publicada. A mulher entrara em contato com Cruso e seu escravo Friday após ter sido desembarcada em uma ilha deserta. Tempos depois, os três personagens são resgatados por um navio inglês. Cruso morre durante a viagem e Susan “adota" Friday, que tivera sua língua retirada. Há a escrita de um diário por Susan. Friday tentará se expressar pela escrita, o que o faz descobrir sua subjetividade, história e autonomia. "Coetzee se integra aos principais autores pós-coloniais para desenvolver sua teoria sobre a escrita e a literatura como meios para a subjetificação dos povos nativos oprimidos". Com essas palavras, o professor Thomas Bonnici apresenta a obra de Coetzee em seu livro "O Póscolonialismo e a Literatura: estratégias de leitura" (2000) e discute questões de colonização e alteridade em Robinson Crusoé.

Também citamos aqui a obra de Michel Tournier, "Vendredi ou les limbes du Pacifique" ("Sexta-Feira ou os limbos do Pacífico").

Traduzida no mundo inteiro, a criação de Defoe desperta tamanho interesse que, em 2006, foi criada a "Sociedade Defoe" (The Defoe Society), um órgão internacional que visa a facilitar as interações entre estudiosos do autor, criar encontros regulares para discussões acadêmicas, construir um website para divulgação de novas publicações, discutir questões pedagógicas em relação à divulgação da obras de Defoe e incentivar o reconhecimento público desse autor e de seu trabalho. O primeiro encontro está marcado para 
25 e 26 de setembro de 2009, na Universidade de Oklahoma, com a participação de vários especialistas.

No dia primeiro de junho de 2009, a "Sociedade Defoe" inaugurou uma página digital. Nela, um artigo de Sharon Alker discorre sobre as possibilidades que a web tem trazido aos estudos de Defoe e às práticas docentes, no sentido de incrementar os estudos do autor por via digital. A Sociedade Defoe possibilita o encontro do pesquisador com muitos títulos de livros, artigos, dissertações e teses. Serão $\operatorname{arrolados}^{35}$ neste trabalho apenas alguns, segundo critérios de afinidade com a tese aqui proposta:

*ANO: 2005:

- Artigos - total 14:

- Marroni, Michela. "The Moonstone di Wilkie Collins: Robinson Crusoe come percorso intertestuale". Confronto Letterario: Quaderni del Dipartimento di Lingue e Letterature Straniere Moderne dell'Universita di Pavila 43 (2005): 193-209.

- Mueller, Andreas. "Daniel Defoe: Master of Genres”. Worcester Papers in English and Cultural Studies 3 (2005): 33-47.

- Rix, Robert W. “The Crusonian Alphabet: Thomas Spence's Grand Repository of the English Language". English Language Notes 43.2 (2005): 69-92.

- Livros e capítulos de livros - total 41:

- Eagleton, Terry. "Daniel Defoe and Jonathan Swift." The English Novel: An Introduction. Malden, MA: Blackwell, 2005.22-52.

- Manguel, Alberto. Pinocchio \& Robinson: Pour une ?ique de la lecture. Essai. Bordeux: Escampette, 2005.

- Novak, Maximillian E., and Carl Fisher, eds. Approaches to Teaching Defoe's Robinson Crusoe. ATWL. New York: MLA, 2005.

- Blackburn, Timothy C. "Robinson Crusoe as Literary Art". Novak and Fisher 105-110.

- Chandler, Anne. "Great Labour and Difficulty: Robinson Crusoe as Introduction to Literary Analysis”. Novak and Fisher 180-185.

- Fisher, Carl. "The Robinsonade: An Intercultural History of an Idea”. Novak and Fisher 129-139.

\footnotetext{
${ }^{35}$ As referências foram inseridas, neste trabalho, exatamente como encontradas na web.
} 
- Kent-Drury, Roxanne, and Gordon Sayre. "Robinson Crusoe's Parodic Intertextuality". Novak and Fisher 48-54.

- Lundin, Anne. "Robinson Crusoe and Children's Literature”. Novak and Fisher 198-206.

- Pollard, Charles W. "Teaching Contemporary Responses to Robinson Crusoe: Coetzee, Walcott, and Others in a World Literature Survey”. Novak and Fisher 161-168.

- Sassi-Lehner, Christina. "Teaching Robinson Crusoé in the Introduction to Literature Course". Novak and Fisher 175-179.

- Schonhorn, Manuel. "Weber, Watt and Restraint: Robinson Crusoe and the Critical Tradition”. Novak and Fisher 55-60.

- Sill, Geoffrey. "Myths of Modern Individualism: Defoe, Franklin, and Whitman". Novak and Fisher 61-68.

- Richetti, Jonh J. The Life of Daniel Defoe: A Critical Biography. Oxford: Blackwell, 2005.

- Womersley, David. "Confessional Politics in Defoe's Journal of the Plague Year." 'Cultures of Whiggism': New Essays on English Literature and Culture in the Long Eighteenth Century. Eds. David Woomersley, Paddy Bullard, and Abigail Williams. Newark, DE:U of Delaware P,2005. 237-256.

- Dissertações e Teses - total - 4:

- Taylor, Rebecca J. "Robinson Crusoe and the Reproduction of Singleness in England's Long Eighteenth Century. Diss. Washingtron U, 2004. DAI 65 (2005): 3402 .

*NO: 2006:

- Artigos - total - 11:

- Oliver, Kathleen M. "Defoe's Poetic Reformation: From Poem to Novel, Pillory to Penitentiary”. CLIO 35 (2006): 157-178.

- Zabus, Chantal. "Fatal Attractors: Adam, Homer, Shakespeare, Defoe, Walcott, and Re-Righting the Caribbean”. Commonwealth Essays and Studies 28.2 (2006): 57-72. 
- Livros e capítulos de livros - total 14:

- Furbank, P.N., and W.R.Owens. A Political Biography of Daniel Defoe. Eighteenth-Century Political Biographics 1. London: Pickering \&Chatto, 2006.

- Glover, Susan P. "The Incomplete Tradesman: Daniel Defoe and the Lay of the Land". Engendering Legitimacy: Law, Property, and Early EighteenthCentury Fiction. Lewisburg, PA:Bucknell UP,2006.

- McKim, Anne. "Adapting News and Making History: Defoe's News Discourses and the History of the Union". News Discourse in Early Modern Britain. Ed. Nicholas Browlees. Linguistics Insights. New York: Peter Lang, 2006.255-272.

- Dissertações e teses - 3:

- Bose, Dev. "The Rhetoric of Surveillance: A Re-appraisal and Reapplication of Focauldian Theory”. MA thesis. California State U, 2006.

- Livingstone, Charlotte. "Daniel Defoe and the Styles of History: Narrative and Historiography in the Long Seventeenth Century". Diss. U of Oxford, 2006.

* ANO: 2007:

- Artigos - 10:

- Marshall, Ashley. "Daniel Defoe as Satirist". Huntington Library Quarterly 70 (2007): 553-576.

- Clark, Katherine. Daniel Defoe: The Whole Frame of Nature, Time, and Providence. New York: Palgrave Macmilln, 2007.

- Martin, John. Beyond Belief: The Real Life of Daniel Defoe. 2nd. Bedlinog, Wales: Aceent, 2007.

- Marzec, Robert P. An Ecological and Postcolonial Study of Literature: From Daniel Defoe to Salman Rushdie. New York: Palgrave Macmillan, 2007.

- McKay, Jenny. 'Defoe's 'The Storm' as a Model for Contemporary Reporting". The Journalist Imagination: Literary Journalists from Defoe to Capote and Carter. Ed. Richard Keeble and Sharon Wheeler. New York: Routledge, 2007. 15-28.

- Novak, Maximillian E. "Edenic Desires: Robinson Crusoe, the Robinsonade, and Utopias”. Historical Boundaries, Narrative Forms: Essays on British 
Literature in the Long Eighteenth Century in Honor of Everett Zimmerman. Ed. Lorna Clymer and Robert Mayer. Newark: U of Delaware P, 2007. 19-36.

- Spence, Mark G. "Daniel Defoe". Eighteenth-Century British Historians. Ed. Ellen J. Jenkis. Detroit: Thomson Galé, 2007. 82-94.

- Dissertações e teses - 4:

- Gorman, Charles M. "Robinson Crusoe: Identity Construction”. MA thesis. U of Alaska Anchorage, 2007.

- Kugler, Emily. Representations of Race and Romance in EighteenthCentury English Novels. Diss. U of California, San Diego, 2007. Ann Arbor: UMI, 2007. ATT 3258372.

ANO: $2008^{36}$ :

- Livros e capítulos de livros - 4:

- Faller, Lincoln B. Crime and Defoe: A New Kind of Writing. Cambridge Stdies in Eighteeth-Century English Literature and Thought. Cambridge: Cambridge UP, 2008.

- Loveman, Kate. "Defoe and His 'Ill-Disposed Readers"'. Reading Fictions, 1660-1740: Deception in English Literary and Political Culture. Burlington,VT; Ashgate, 2008.

- Dissertações e teses - 5:

- Jones, Radhika. "Required Rereading, or how Contemporary Novels Respond to the Canon”. PHD. Diss. Columbia University, New York, 2008.

- Pearl, Jason - "New words and New Worlds in the Age of Crusoe and Gulliver”. Boston, University, 2008.

Em pesquisa realizada na "Biblioteca Digital Brasileira de Teses e Dissertações", com acesso em 4 de abril de 2009, foram registrados os seguintes resultados à consulta com a palavra-chave "Robinson Crusoé":

- Carvalho, Diógenes Buenos Aires de - A adaptação literária para crianças e jovens - Robinson Crusoé no Brasil. Pontifícia Universidade Católica do Rio

\footnotetext{
${ }^{36}$ Útimo acesso em 2 jul. 2009.
} 
Grande do Sul: Rio Grande do Sul, 2006. Orientadora: Profa. Dra. Vera Teixeira Aguiar.

- Lemos, Helena Maria Roennau. The dark side is the bright side, in Robinson Crusoe: a transdisciplinary reading of Daniel Defoe as novel. Universidade Federal do Rio Grande do Sul: Rio Grande do Sul. 2006: Orientadora: Sandra Sirangelo Maggio.

- Moraes, Sinara Gislene Foss. Coetzee's Foe: a reading on history and fiction. Universidade Federal do Rio Grande do Sul, 2008. Orientador: Sandra Sirangelo Maggio.

Em "Buscausp.br", à menção "capitalismo e Robinson Crusoé”, entre referências de tipos variados (como exibição de filmes), selecionamos os seguintes trabalhos:

- Helena, Lucia. A solidão tropical e os pares à deriva: reflexões em torno de Alencar. (Neste trabalho Robinson Crusoé é tomado como ponto de partida para a construção do tema da solidão na obra de Alencar). O texto foi publicado em LusoBrazilian Review, no 41: p.01-18, 2004 -The University of Wisconsin, Madison.

- Moreira, Maria Salete de Uzeda. A construção do herói e as narrativas de aventura: D. Quixote e Robinson Crusoé. 2005. Orientadora: Maria Augusta da Costa Vieira.

Constando de jornais e revistas, textos da professora Maria Ligia C. Prado, professora titular de História da América Independente na Universidade de São Paulo, foram publicados no início da década de noventa:

- O colonialismo revisitado: a saga de Robinson Crusoé e Sexta-Feira. Padê, Salvador, n.1, p.29-36, 1989.

- Um heroe moderno: Robinson Crusoé. El Clarin, Buenos Aires, p.3. $12 / 10 / 1992$

- A saga de Robinson Crusoe e Sexta-Feira. Jornal da Tarde, São Paulo, 9 de julho de 1992.

Em 2006, a referida professora apresentou um trabalho em sessão de comunicação intitulado "Robinson Crusoé: Diálogos entre o Velho e o Novo Mundo" (a informação foi obtida em seu Currículo Lattes e não apresenta maiores detalhes). 
Há ainda que se referir aos estudos do professor Luiz Carlos Villalta. No "I Seminário Brasileiro sobre Livro e História Editorial”, ele apresentou um trabalho intitulado "Robinson Crusoé, de Daniel Defoe: de sua circulação no mundo luso-brasileiro ao seu diálogo com o devir histórico", disponível em versão digital ${ }^{37}$.

Em nosso país, Robinson Crusoé é obra de grande circulação no mercado de livros destinado às crianças e jovens. Em diferentes produções com grande diferenciação no número de folhas, aparece com ilustrações - coloridas ou não, publicadas por diferentes editoras e com trabalhos de diversos adaptadores.

De acordo com um levantamento bibliográfico de adaptações brasileiras da obra Robinson Crusoé abarcando os anos de 1882 a 2004, realizado pelo professor Diógenes Buenos Aires de Carvalho, da Pontifícia Universidade Católica do Rio Grande do Sul, a data mais antiga remete à autoria de Carlos Jansen, em 1885, publicada pela editora Laemmert. Sobre a introdução desse romance inglês no Brasil, a pesquisa de Luiz Carlos Villalta, professor do Departamento de História da Faculdade de Filosofia e Ciências Humanas da Universidade Federal de Minas Gerais, indica que o primeiro envio é datado de 1796, proveniente de Portugal, com autorização de entrada dada pela Real Mesa Censória Portuguesa.

No que se refere à presença da obra de Defoe no Brasil, encontramos referências em diferentes textos da coletânea organizada por Márcia Abreu, professora livre-docente do Departamento de Teoria Literária do Instituto de Estudos da Linguagem da Unicamp, intitulada "Trajetórias do Romance: circulação, leitura e escrita nos séculos XVIII e XIX". Integrante da obra, o professor Nelson Schapochnik, no seu texto "Sobre a leitura e a presença de romances nas bibliotecas e gabinetes de leitura brasileiros", aponta que, num catálogo referente a obras da primeira biblioteca pública instalada no Brasil, na Bahia, há "um indício pontual que permite inferir a existência de uma tradução de Daniel Defoe nas estantes da biblioteca baiana, indicada apenas por Vie de Robinson" (2008, p.160). No texto "Em busca de romances: um passeio por um catálogo da Livraria Garnier”, Juliana Maia de Queiroz constata a presença das "Aventuras de Robinson Crusoé" dentre os pouco numerosos autores ingleses editados pelo conhecido francês radicado no Rio de Janeiro, Baptiste Louis Garnier. Por 44 anos, Garnier exerceu a função de livreiro-editor no Rio de Janeiro, tendo publicado livros de diferentes temáticas e gêneros, de autores nacionais e estrangeiros. A respeito da referência à pouca quantidade de autores ingleses no Brasil dessa época, a autora remete ao

\footnotetext{
${ }^{37}$ Disponível em: www.caminhosdoromance.iel.unicamp.br/estudos/ensaios/crusoe.pdf. Acesso em 22 fev.2007.
} 
estudo da professora Sandra Guardini de Vasconcellos, "A formação do romance brasileiro: 1808-1860", lembrando que muitas obras traduzidas do francês eram, na realidade, de autores ingleses. Em "Lugares de compra, itinerários de leitura: circulação de romances em Fortaleza oitocentista", Ozângela de Arruda Silva mostra que, já em 1848, havia, em Fortaleza, na loja de variedades do comerciante português Manoel Antonio da Rocha Junior, um exemplar de Robinson Crusoé, numa parte da loja, separada para venda e aluguel de livros.

Dos dados que atravessam momentos mais distantes da nossa historicidade, chegamos às possibilidades de leitura de Robinson Crusoé em textos eletrônicos, disponíveis na web. O site do professor Oswaldo de Almeida Junior ${ }^{38}$, associado ao Departamento da Ciência da Informação da Universidade Estadual de Londrina, veiculou a seguinte notícia ${ }^{39}$ :

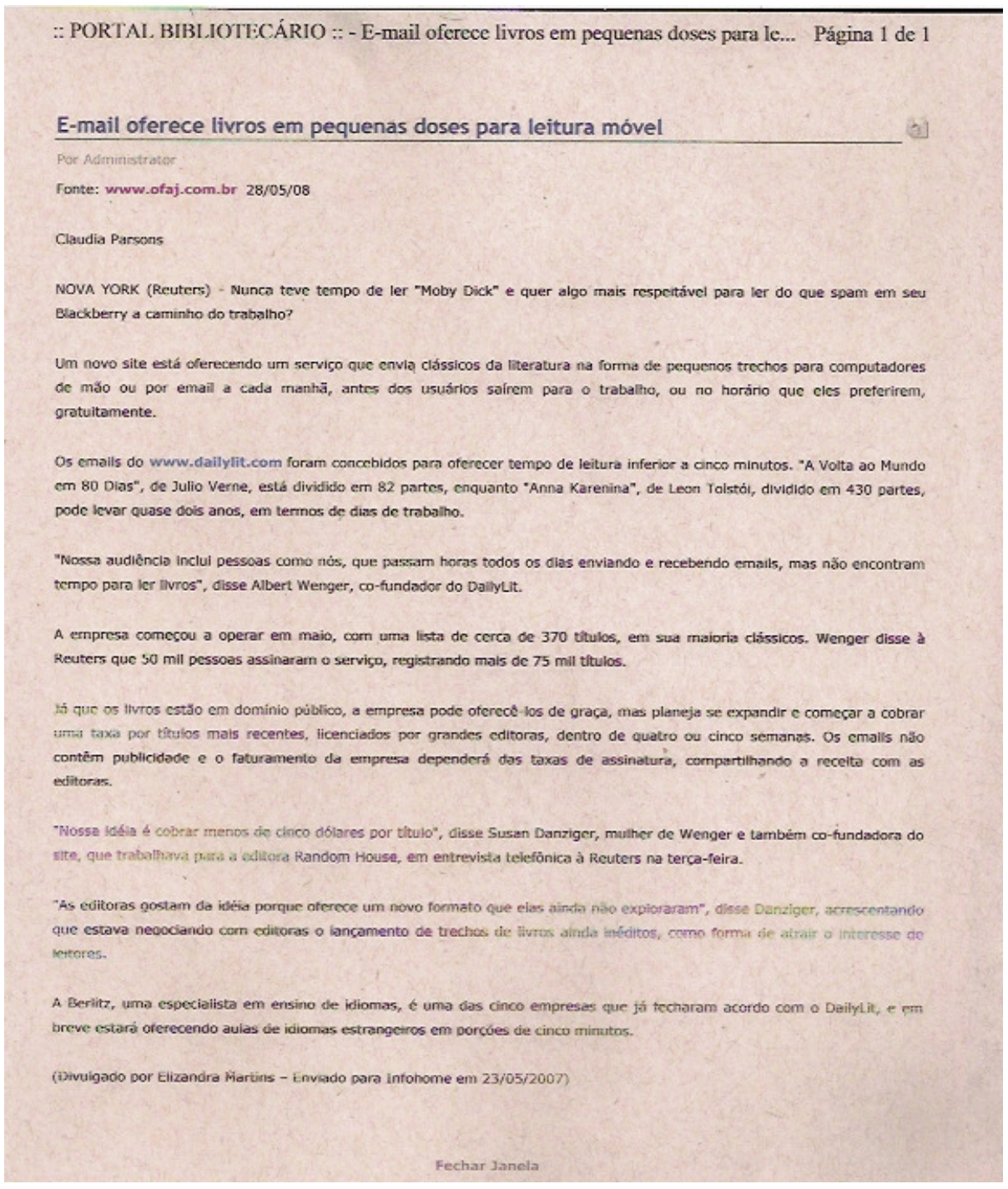

Figura 3: E-mail - Portal do Bibliotecário.

\footnotetext{
${ }^{38}$ Disponível em: http://www.ofaj.com.br. Acesso em: 2 jul. 2009.

${ }^{39}$ Transcrita integralmente no Anexo D.
} 
A história de Robinson foi também incorporada por outros gêneros narrativos, como quadrinhos e cordel.

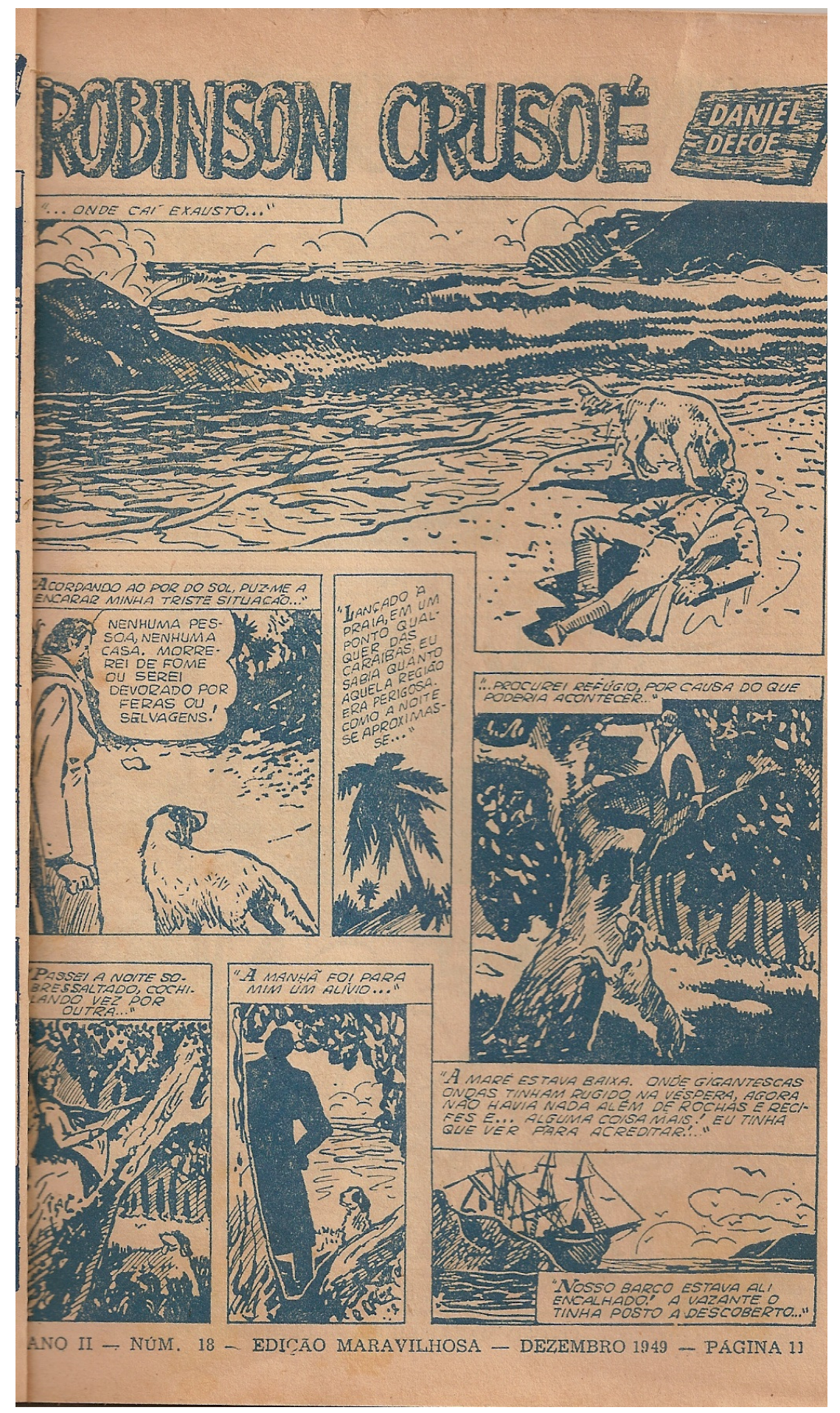

Figura 4: Página interna da Revista Robinson Crusoé (quadrinhos) - Edição Maravilhosa.

Robinson Crusoé no instante de seu salvamento e a primeira noite na ilha. Da Coleção Clássicos Ilustrados - 1949. 


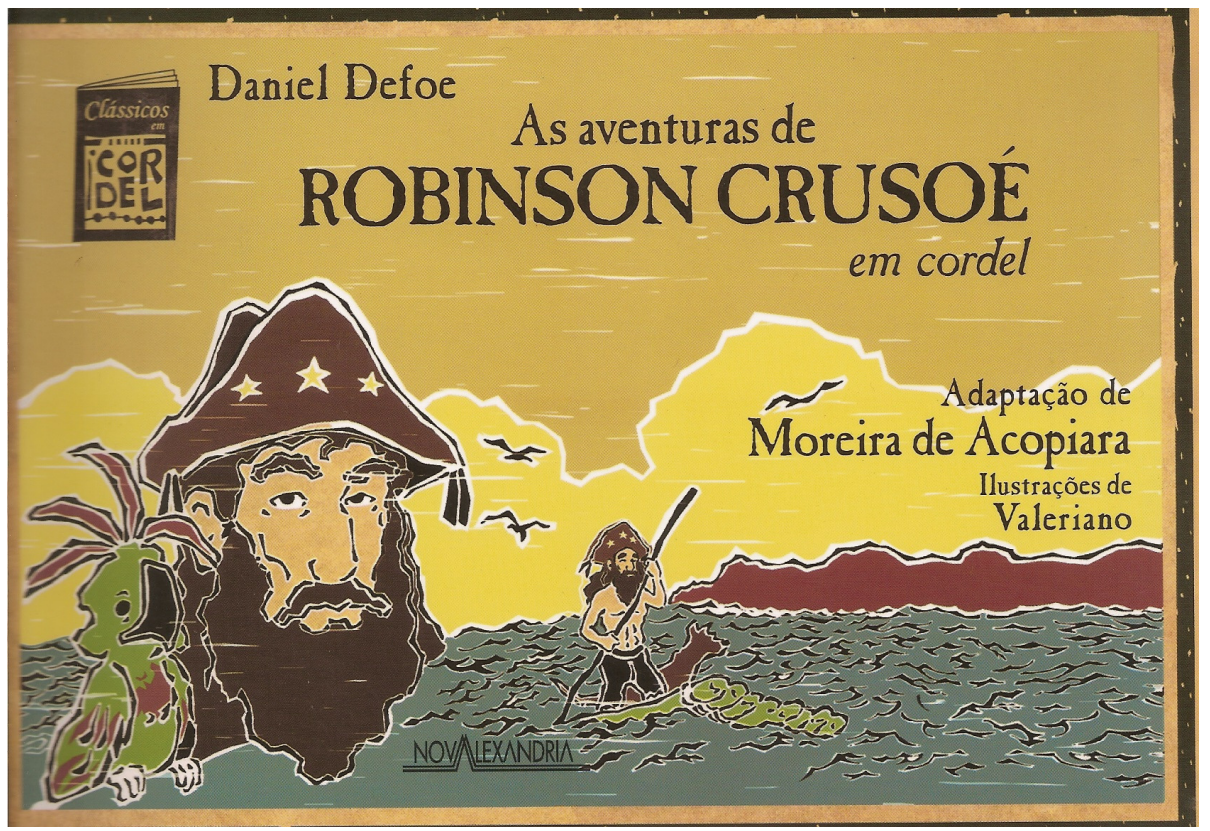

Aprendeu a ordenhar

E gostou desse exercício;

Depois de um tempo e após

Muita luta e sacrifício

Aprendeu a fazer queijo,

E acabou-se o desperdício.

Assim, os súditos do reino

Correspondiam somente

A quase cinquenta cabras,

Um cão já velho e doente

$\mathrm{E}$ um papagaio que andava

Cada vez mais decadente.

Um dia, andando na praia

Para esquecer os percalços,

Enxergou, apavorado,

Marcas de dois pés descalços.

Correu pra casa querendo

Crer que eram alarmes falsos.
Chegou em casa ofegante E se sentindo acuado; Dominado pelo medo Passou três dias trancado, Só depois disso saiu, Mas muito preocupado.

Pra acabar de complicar, Ao transpor umas barreiras Encontrou um descampado Com resquícios de fogueiras $\mathrm{E}$ ao seu redor pelo menos Uma dúzia de caveiras.

A partir desse momento Perdeu o resto da paz; Se existia alguma dúvida, Agora não tinha mais: Aquele reduto era Um antro de canibais.

Figuras 5 e 6: Capa e página interna do livro "As aventuras de Robinson Crusoé em cordel" - Editora Nova Alexandria.

Robinson Crusoé torna-se rei em sua ilha. Mas um dia, encontra marcas na areia... 


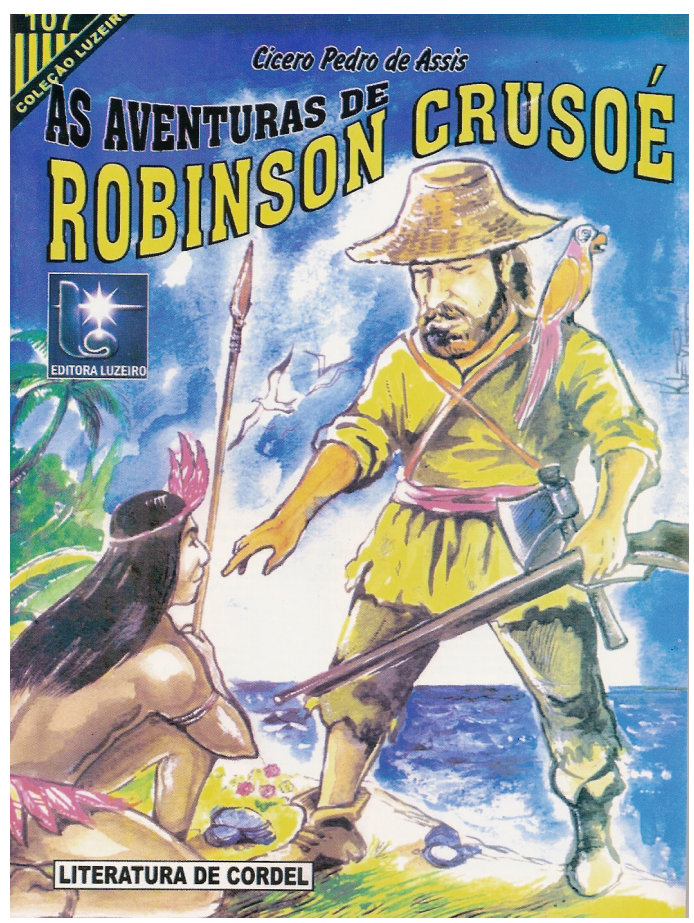

\section{Cicero Pedro de Assis}

Não sei se aquela era a terra Que eu queria conhecer, Mas acredito que era.

Ao certo não sei dizer

Se era mesmo a vasta terra Que à distância pude ver.

Naquele lugar dormi

$E$, só na manhã seguinte, Voltei pra minha barraca. Da minha história o ouvinte Sabe bem que o que passei Da sorte parece acinte.

Vi na areia da praia

Um sinal surpreendente:

A marca de pé descalço

E era rastro de gente.

Por certo não era a minha

A pegada do vivente.

Desejei durante anos

Encontrar um companheiro,

Para repartir meus sonhos,

Pois passava o tempo inteiro

Sem ter com quem conversar,

$\mathrm{Na}$ ilha prisioneiro.

Eu, que desejava tanto

Ter alguém na companhia,

Descobrindo aquela pista,

Em vez de ter alegria

Me senti apavorado

E meu corpo até tremia.

Investiguei o mistério,

Procurando desvendá-lo:

Vasculhei a praia toda

Sem, contudo, decifrá-lo.

Corri aterrorizado;

Não pude mais procurá-lo.

Os mais doidos pensamentos Tive na imaginação.

Pensei ser do tentador

Aquela marca no chão,

Mas repensando o achado

Outra foi a conclusão.

Era sim de algum selvagem

A pegada na areia,

E era de canibal.

Vi que a coisa estava feia!

Pra mim, que vivia só,

O sangue gelou na veia.

Num lugar de minha ilha Onde nunca tinha estado,

De uma elevação dali

Vi um vulto ter chegado.

Em virtude da distância

Foi por mim pouco sondado.

Mesmo longe, foi possível

Conseguir observar

Um horroroso espetáculo

De fazer arrepiar:

Restos humanos dispersos,

Que não quero nem lembrar.

Diante daquela cena

Amargou minha garganta,

Me senti ameaçado

Como que por salamanta

De um veneno tão mortal

Que nenhum soro suplanta.

Minha ilha realmente

Havia tido a presença

De temíveis antropófagos.

Isso já me trouxe ofensa.

Pois fiquei estarrecido

Com a mente muito tensa.

Figuras 7 e 8: Capa e página interna da revista "As aventuras de Robinson Crusoé" (literatura de cordel) - Editora Luzeiro. 
Quanto à linguagem cinematográfica, há produções calcadas na própria obra de Defoe ou em releituras. Citamos alguns diretores:

- 1932 - Edward Sutherland ("Mr. Robinson Crusoe").

- 1952 - Luís Bunuel ("Robinson Crusoé”).

- 1964 - Byron Haskin ("Robinson Crusoe em Marte”).

- 1968 - John Boorman ("Hell in the Pacific").

- 1975 - Jack Gold (“Man Friday”).

- 1988 - Caleb Deschanel (“Crusoe”).

A cadeia discursiva que envolve Robinson passa também pelo humor dos cartoons $^{40}$ e, no mundo dos negócios, torna-se referência privilegiada de propagandas de turismo em ilhas paradisíacas.

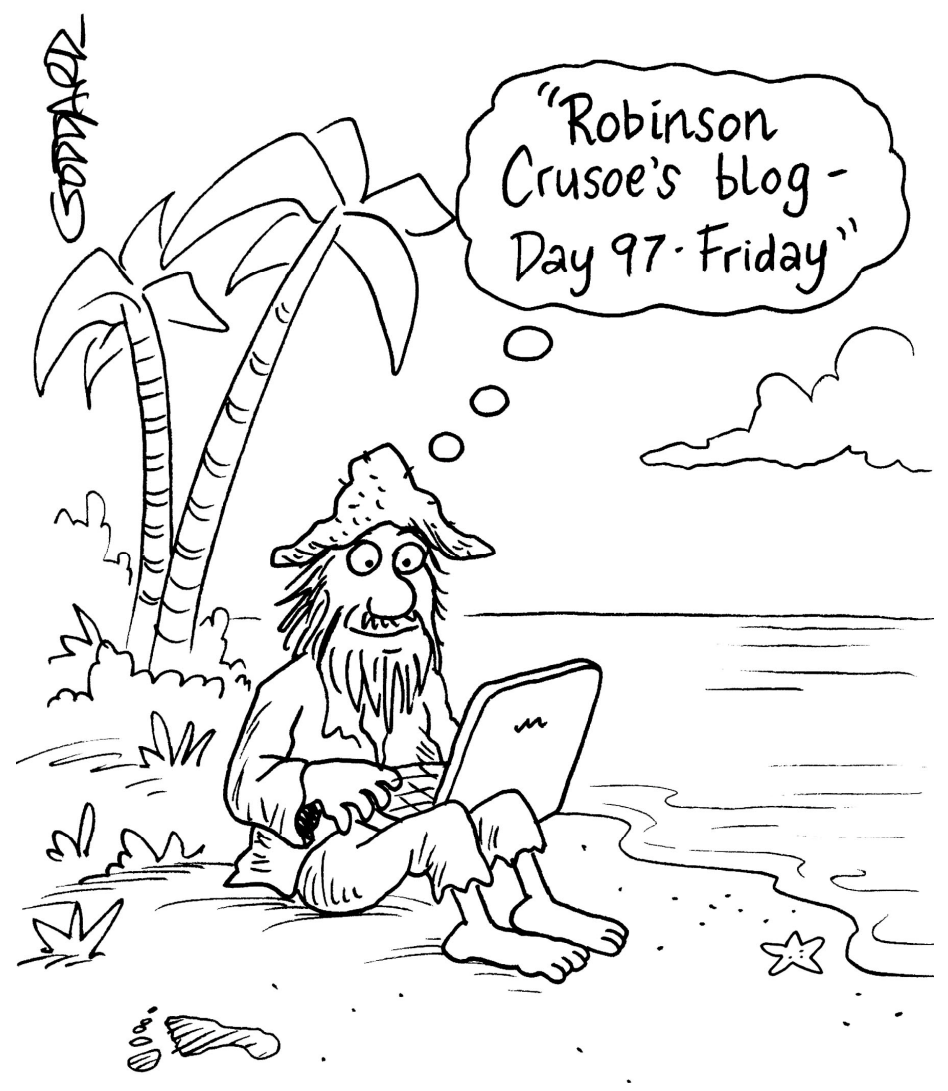

Figura 9: Cartoon - autor: Clive Goddard.

\footnotetext{
${ }^{40}$ Os direitos de uso dos cartoons para esta tese foram adquiridos no site: www.CartoonStock.com
} 


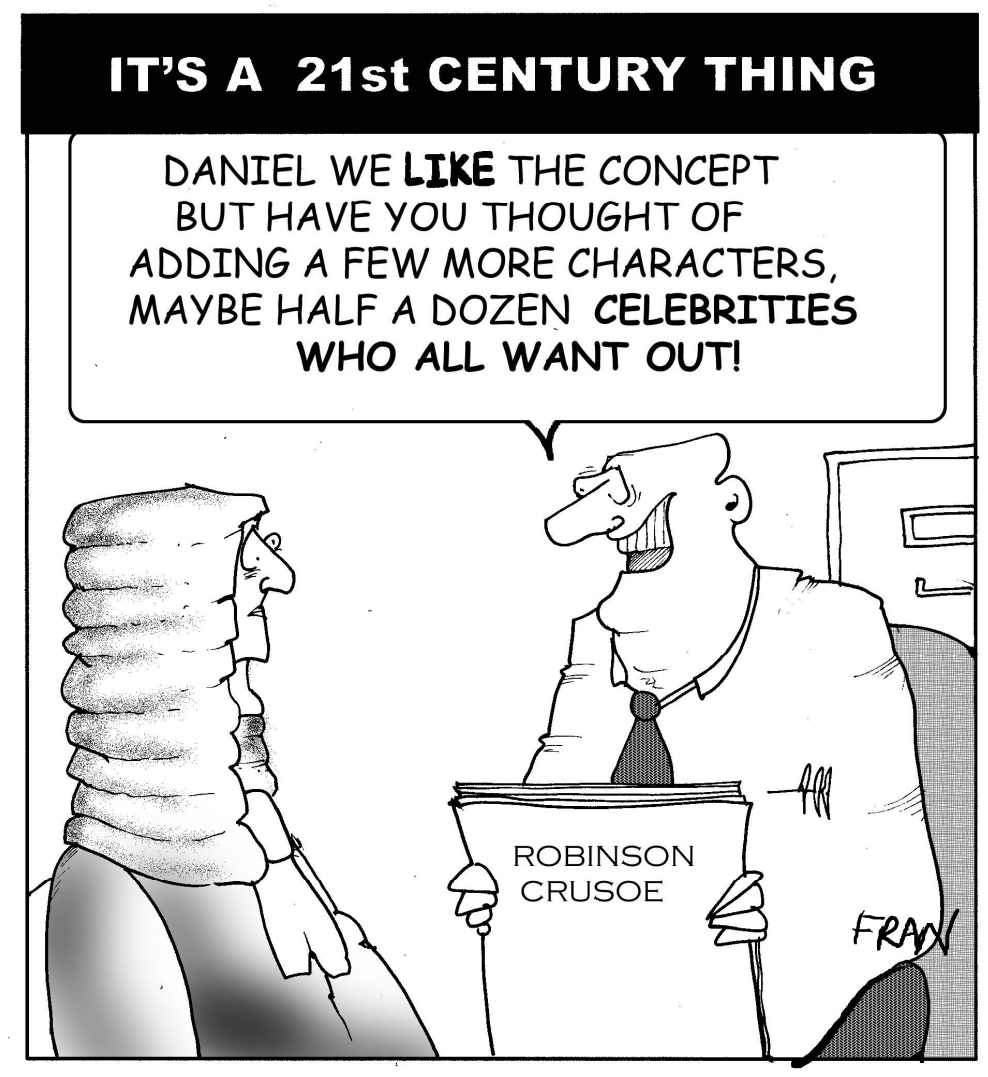

Figura 10: Cartoon - autor: Fran.

Na premiação do ano de 2009 da "Feira de Livros para Crianças", em Bologna, a obra "Robinson Crusoé", um livro de imagens criado por Ajubel, pela Editora Media Vaca, foi a vencedora na categoria de ficção. Foi esta a opinião do júri: "Com ousadia, Ajubel apropria-se do casamento tradicional entre texto e imagem, elevando-o a um nível novo e superior. $O$ que parece a princípio ter partido do tradicional mostra-se, em um exame cuidadoso, ser exatamente o oposto".

Se alguns fios dessa cadeia de discursos foram apontados, cabe aqui uma pergunta: como esta pesquisa insere-se nela?

\section{METODOLOGIA}

Esta pesquisa busca apresentar uma leitura singular, motivada pelas palavras de Fiorin (2006) de que a leitura de uma obra é simultaneamente social e individual, pois, ao se 
colocar como participante de um diálogo em torno de um determinado texto, a compreensão do leitor é tributária de “outras compreensões”. Por mobilizar as próprias leituras e criar uma "resposta ativa", o leitor/pesquisador apresenta sua leitura singular. Nas palavras de Bakhtin (2003, p.378-379), em forma de apontamentos, encontramos o incentivo para nos movermos dentro da profusão de referências e reflexões feitas à obra de Defoe:

[...] a compreensão completa o texto; ela é ativa e criadora. A compreensão criadora continua a criação, multiplica a riqueza artística da humanidade. A co-criação dos sujeitos da compreensão.

[...] O sujeito da compreensão enfoca a obra com sua visão de mundo já formada, de seu ponto de vista, de suas posições. [...] O sujeito da compreensão não pode excluir a possibilidade de mudança e até de renúncia aos seus pontos de vista e posições já prontos.

[...] A diretriz exclusiva no reconhecimento, na busca apenas do conhecido (do que já existiu), não permite descobrir o novo (isto é, o principal, a totalidade não repetível). A metodologia da explicação e da interpretação se reduz com muita freqüência a essa descoberta do repetível, ao reconhecimento do já conhecido, e se percebe o novo o faz apenas em forma extremamente empobrecida e abstrata.

Que não se entenda aqui uma pretensão acima das possibilidades reais em que se insere este trabalho de pesquisa, mas que se tomem as palavras de Bakhtin como um encorajamento à ousadia e à seriedade necessárias ao pesquisador.

Nessa leitura, estabelece-se o esforço de dialogar com o passado e a tentativa de não submergir a voz do pesquisador, a fim de fomentar a continuação das interações verbais em torno da obra de Defoe e de aspectos por ela sugeridos. Para isso, a escrita do trabalho contará com várias citações por acreditar que elas são constituintes de uma relação dialógica. Entendo, junto com Manguel, que citar é refletir sobre o que já foi dito, é continuar um diálogo com o passado; e o autor cita Walter Benjamin: "Escrever história é citá-la" (apud MANGUEL, 2001, p.85).

A leitura do romance em primeira pessoa faz-me estabelecer um acordo com o personagem e seu pacto autobiográfico. A leitura da pesquisadora leva-me a interrogar a obra. O objeto pesquisado, o contexto extratextual da pesquisa e sua autora são constitutivos do trabalho realizado. Encontros e desencontros, vida e desafios gestaram e produziram o trabalho aqui apresentado.

Este iniciou-se pelo levantamento de dados numéricos referentes a Robinson Crusoé, o qual apresentou resultado tão numeroso que seria de se esperar que representasse um desestímulo à continuação da pesquisa. Contudo, uma instigação sempre persistia. Alinhada à visão da presença do social na ilha deserta, à importância da cultura e da memória 
na preservação da vida do náufrago, eu permanecia intrigada com as questões do funcionamento da linguagem, dado que Robinson estava sem contato humano (pelo menos por 25 anos); e a reflexão sobre este tema é considerada por mim como de fundamental importância nos dias de hoje, especialmente para os envolvidos com a educação e a cultura.

As abordagens de Barthes e Certeau apontavam importantes reflexões sobre Robinson e linguagem, mas eu estava instigada a buscar as formas pelas quais ele tinha se utilizado deste dado primordial da cultura humana: a palavra.

Nessa perspectiva, os estudos de Mikhail Bakhtin revelaram-se inspiradores e alicerces da pesquisa, especialmente no que se refere ao caráter dialógico da linguagem, à dialogia interna da palavra, que possibilitaria uma leitura diferenciada da vida do ser solitário.

Assim, o trabalho de realizar uma leitura das "Singulares Aventuras de Robinson Crusoé" foi impulsionado pelo conceito bakhtiniano de dialogia da linguagem, na perspectiva de refletir e buscar encaminhamentos sobre a seguinte hipótese: Robinson, ao lado de tantas representações que lhe são atribuídas, pode ser considerado um paradigma do homem enquanto ser de linguagem, se verificadas representações da palavra do Outro nos seus discursos de homem solitário?

É importante destacar que não se trata de uma análise bakhtiniana do texto. Esta empreitada exige conhecimentos aprofundados sobre linguística e metalinguística que não fizeram parte da formação da pesquisadora. A proposta desta pesquisa é sinalizar a possibilidade de novas leituras revitalizantes de uma obra clássica, assumindo, no caso específico da obra estudada, a sua referência como paradigma do homem enquanto ser de linguagem, metalinguístico (conceito que será esclarecido no decorrer do trabalho).

A metodologia constou de seleção inicial da edição a ser estudada, dentre diferentes exemplares arrolados. O critério de escolha pautou-se pela integralidade do texto e pela data de publicação, de tal forma que se referisse à segunda metade do século XX (já que também foram conseguidos livros de 1925 e 1940). Feita a opção, realizaram-se leituras e releituras da obra, acompanhadas de estudos teóricos de diferentes autores.

Inicialmente houve uma posição de caminhar junto ao personagem, sem questioná-lo. À medida que as leituras se sucediam, foram buscados os atos de linguagem de Robinson durante o tempo em que esteve absolutamente só, isolando-os de seus contextos de enunciação. A fim de categorizá-los, foram formuladas questões iniciais, interrogando-os:

- Com quem Robinson falava?

- O que expressava em voz alta?

- Quais eram os seus monólogos interiores? 
- Qual o significado da escrita do seu diário?

- Que perguntas formulava?

- Obtinha respostas às suas perguntas?

Para melhor entendimento do trabalho realizado, consideramos importante um conhecimento mínimo do arcabouço teórico que conduziu a análise, ou seja, o conceito de dialogismo da linguagem, expresso pelo Círculo de Bakhtin. Assim, em vista de tal razão, os demais passos do percurso metodológico serão explicitados na Parte Dois desta tese, após a formulação das concepções fundamentais à compreensão do estudo apresentado.

Há dois objetivos envolvidos neste projeto de tese:

- questionar um possível uso de obras clássicas como fetiches, cristalizadas em um cânone que, justificando infindáveis adaptações, não incita à preservação e/ou ampliação dos sentidos da obra, desvitalizando-as.

- buscar ampliação de sentidos da obra de Defoe, na busca de caracterizá-la como paradigmática do homem como ser de linguagem.

A edição adotada para estudo data de 1975; é um livro de bolso das Publicações Europa-América, em texto integral. Foi escolhido em função da Nota Prévia escrita pelo seu editor. Diz ela:

\footnotetext{
"Robinson Crusoé, mais precisamente A Vida e as Surpreendentes e Singulares Aventuras de Robinson Crusoé, de Iorque, Marinheiro, é uma das mais célebres obras da literatura inglesa. Ao apresentar a versão portuguesa do seu texto integral, pareceu útil fazê-la preceder de uma nota explicativa que ajudasse o leitor a situar a obra na sua justa perspectiva. [grifo nosso].

1. Como se sabe, o tema central da obra é a vida solitária de um náufrago que arribou a uma ilha tropical completamente deserta e ali fez, consequentemente, todo um trabalho de conquista individual no plano do domínio da natureza, até conseguir condições de vida que lhe permitissem sobreviver. [...]

2. Quem se der ao trabalho de analisar a linguagem de Daniel Defoe em Robinson Crusoé facilmente concluirá que o autor escrevia e falava um inglês vulgar de classe média, sem polimento de qualquer espécie, e que não tinha o mais pequeno respeito pela gramática. Por isso o seu texto é de difícil tradução, sobretudo quando se renuncia a fazer adaptações, truncando o texto para o aligeirar, e se pretende - como nós fizemos - apresentar uma tradução do texto integral, conservando, na medida do possível, o seu sabor original. Aliás, este esforço de traduzir o texto tal como Defoe o concebeu é largamente compensado, pois a vitalidade de estilo que dele resulta é de tal ordem que faz esquecer as suas "inconveniências" gramaticais.

3. Como explicar o êxito deste livro, que, apesar da sua incorrecção formal, se situou na galeria das obras imortais da literatura de sempre?
} 
Várias razões parecem de apontar, e na convergência de todas elas se encontrará a resposta satisfatória.

Em primeiro lugar, está a tal vitalidade de estilo de que o autor dá provas e que embala o leitor da primeira à última página. [...]

Uma segunda razão que poucos dos que lhe sentiram o encantamento terão conscientemente identificado está no facto de o livro ser uma exaltação do poder do homem. Afinal, o que se desprende ao longo de toda a história é a maravilhosa capacidade do ser humano para dominar a natureza e a pôr ao seu serviço. A história de Robinson Crusoé funciona como o catalisador individual da longa caminhada do progresso que a humanidade foi fazendo pelos séculos fora.

Por último (the last, but not the last [sic]), está o tom de veracidade que Defoe conseguiu emprestar à sua prosa. Esta impressão de veracidade consegue-a o autor pelo "amontoar de inúmeros pormenores aparentemente triviais, até o cérebro do leitor estar exausto e apto a aceitar. Inconscientemente, sente-se que esta vasta acumulação de trivialidades é tal qual a vida, e, então, tem que ser verdade."

Daqui resulta o inconveniente das edições abreviadas. Muitas se têm feito com o intuito de aligeirar o volume e de fazer de Robinson Crusoé um livro para rapazes. O resultado é roubar-se ao leitor a possibilidade de conhecer uma das características que mais profundamente marcam de originalidade a obra de Defoe.

Até por isso, é para nós motivo de satisfação oferecermos ao leitor português a versão do texto integral de A Vida e as Surpreendentes e Singulares Aventuras de Robinson Crusoé, de Iorque, Marinheiro. Limitámo-nos, para facilitar a leitura, a dividir o texto de acordo com o conteúdo, assinalando com asteriscos a passagem de um episódio a outro.

$O$ Editor

Optar por uma obra em versão portuguesa, feita no século $\mathrm{XX}$, em condição de livro de bolso, não é isento de implicações. Traduzir é uma arte que exige diálogo entre línguas. As intervenções editoriais e a materialidade do texto implicam diferentes formas de ler, como colocam os estudos de Roger Chartier. Sem nos determos nesses aspectos importantes nos atos de leitura, ressaltamos a importância dos estudos desse historiador da cultura.

A escolha de uma obra literária para descortinar a constituição dialógica da linguagem assenta-se na crença de que seres de papel e seus enunciados são interlocutores de seres de carne e osso. Quer estejam nas páginas de papéis reciclados, quer estejam em aparatos tecnológicos como o Kindle ${ }^{41}$, eles falam e respondem a nós, numa circulação de discursos que sustentam a realidade e a fantasia humanas.

\footnotetext{
${ }^{41}$ Hardware portátil e software de leitura desenvolvidos pela Amazon.com para leitura de e-books e outras mídias digitais. Já existem o Kindle, Kindle 2 e Kindle DX, este último anunciado em maio de 2009.
} 
PARTe 2 



\section{A CONCEPÇÃO DIALÓGICA DA LINGUAGEM}

Se a linguagem é tomada neste trabalho como o caminho para se refletir sobre o humano, ela foi pensada em mão dupla de uma mesma via: a linguagem enquanto discurso cotidiano de Robinson Crusoé e a linguagem literária formulada por Defoe.

O relato autobiográfico de Robinson Crusoé mostra-o como condenado à melancolia de uma vida silenciosa. No entanto, sua experiência na ilha é repassada aos leitores como plena de discursos interiores, falas, gestos e leituras. Ou seja, uma experiência plena de atos de linguagem. De que natureza seriam tais atos?

Poderíamos considerar as falas do personagem como expressões individuais de seu psiquismo, pressionado por uma situação-limite. Dono de suas palavras (retiradas de um sistema abstrato de formas linguísticas e com conteúdo ideológico), Robinson expressa sua consciência individual, estabelecendo um dualismo entre um conteúdo interior e uma objetivação exterior desse conteúdo. É do interior de si mesmo que brota um material a ser "traduzido". Ele é o proprietário inalienável de suas palavras. Assim, analisar as falas de Robinson, entendidas como expressões pessoais, seria analisar um conteúdo, de fonte interior, objetivado. Nessa perspectiva, a língua materializa-se em atos individuais de fala.

Em outra perspectiva, as falas de Robinson poderiam ser concebidas como materialização de formas linguísticas aprioristicamente dadas por uma língua pronta e herdada, produto de criação coletiva e normativa para cada indivíduo. Atreladas a um sistema linguístico sem vinculações com a história, não teriam uma origem individual. Fora de um fluxo de comunicação verbal, as falas de Robinson seriam acontextualizadas (seria indiferente o contexto da situação-limite vivida pelo personagem), sem marcas ideológicas.

Uma outra possibilidade de abordagem seria considerar, para além do ato fisiológico de materialização de sons, a materialização de signos verbais, quando, então, atentaríamos para o produto dos atos de fala - os enunciados e suas enunciações. Sem serem considerados de natureza individual, sem serem explicados pelas condições psicofisiológicas do ser falante, os enunciados apresentar-se-iam como de natureza essencialmente social.

Um questionamento pode seguir-se à menção desta última abordagem: como considerar os atos de linguagem de Robinson Crusoé como sendo de natureza social e não individual, dado que o personagem vivia em estado de completo isolamento humano? Seus atos de linguagem poderiam ser considerados enunciações? 
Esclarecimentos fazem-se necessários para entender os conceitos mencionados, constituintes de uma rede complexa de reflexões.

Enunciados e enunciações são conceitos utilizados pelo Círculo de Bakhtin, grupo no qual Mikhail Bakhtin, filósofo da linguagem e profícuo pensador, junto com outros intelectuais, marcou profundamente as formas de pensar a linguagem e a cultura na primeira metade do século XX. Embora tais conceitos sejam utilizados por diferentes linhas de estudos de linguagem, com diversos sentidos, adota-se, aqui, a ótica desses intelectuais.

Devido à complexidade do pensamento de Mikhail Bakhtin, é preciso formular explicações mais extensas do que, simplesmente, transcrever definições. É importante, pelo menos, indicar, mesmo que brevemente, concepções que sustentam seu arcabouço teórico.

É particularmente difícil separar um aspecto da teoria bakhtiniana para ser estudado, visto o imbricamento de todos os conceitos que o pensador russo formula. Nos estudos de linguagem, aos quais trouxe nova perspectiva na busca de formas de construção e instauração do sentido, os estudos de Bakhtin caminharam "pela abordagem linguísticodiscursiva, pela teoria da literatura, pela filosofia, pela teologia, por uma semiótica da cultura, por um conjunto de dimensões entretecidas e ainda não inteiramente decifradas" (BRAIT, 2005a, p.88).

A teoria de linguagem de Bakhtin tem o caráter dialógico da linguagem como essência de sua formulação.

A visão dialógica da linguagem advém da dialogia da vida. Ela é uma visão de mundo e uma forma de escrita. Beth Brait, estudiosa da obra bakhtiniana, em seu texto intitulado "As vozes bakhtinianas e o diálogo inconcluso" (2003, p.12) afirma:

A complexidade do pensamento bakhtiniano, que rejeita a dominância de leituras excludentes, configura uma filosofia de linguagem que, concebendo o eu e o outro como inseparavelmente ligados e tendo como elemento articulador a linguagem, pode espelhar, por um certo prisma e de maneira ideal, o diálogo entre Deus e o homem (FRANK, 1990, p.24).

Falar em dialogia da linguagem é falar que, no processo de comunicação, todos os enunciados mantêm relações de sentido. Para melhor compreensão, é preciso saber que Bakhtin estabelece uma diferença entre unidades da língua e unidades reais de comunicação.

O pensador russo (1999, p.124) considera que "a língua vive e evolui historicamente na comunicação verbal concreta, não no sistema lingüístico abstrato das formas da língua, nem no psiquismo individual dos falantes”. Assim, para ele, a verdadeira substância da língua é um fenômeno social, o fenômeno da interação verbal; ou seja, o autor 
busca examinar o funcionamento real da linguagem para além do sistema (Linguística) que permite esse funcionamento, propondo a criação de uma translinguística (ou metalinguística, em algumas traduções). Em outras palavras, se as unidades da língua são os sons, as palavras e as orações, as unidades reais de comunicação são os enunciados.

Como distinguir, porém, uma unidade da língua de um enunciado?

O enunciado enraíza-se em uma situação de vida, de onde parte a energia que o produz; é daí, portanto, que brota o discurso verbal de tal forma que a situação extraverbal que o engendrou não se constitui meramente numa moldura, num contexto da enunciação, mas faz parte integrante de sua elaboração. Nesse sentido, afirma-se que, num enunciado, há muito mais do que somente fatores linguísticos. Recorremos à citação de Beth Brait, extraída do texto do autor "Discurso na vida e discurso na arte - sobre poética sociológica" (2005b, p.67):

Assim, a situação extraverbal está longe de ser meramente a causa externa de um enunciado - ela não age sobre o enunciado de fora, como se fosse uma força mecânica. Melhor dizendo, a situação se integra ao enunciado como uma parte constitutiva essencial da estrutura de sua significação. Consequentemente, um enunciado concreto como um todo significativo compreende duas partes: (1) a parte percebida ou realizada em palavras e (2) a parte presumida. [...] A característica distintiva dos enunciados concretos consiste precisamente no fato de que eles estabelecem uma miríade de conexões com o contexto extraverbal da vida, e, uma vez separados deste contexto, perdem quase toda a sua significação - uma pessoa ignorante do contexto pragmático imediato não compreenderá estes enunciados.

Como entender o que foi dito por Robinson "Ah, se ao menos estivesse aqui um ou dois", se não soubéssemos de sua frustração ao ver o naufrágio de um barco que se aproximara da ilha em que vivia em extrema solidão, dado o próprio naufrágio que sofrera?

Pelo exemplo citado, podemos perceber que a situação imediata geradora do enunciado liga-se a um contexto maior, que se amplifica, mostrando relações com outros enunciados, discursos e sujeitos.

Se os sons, palavras e orações são unidades da língua e podem ser repetidos, os enunciados, pelo seu imbricamento em situações reais, constroem-se num contexto de enunciação único, sendo, portanto, irrepetíveis e fugazes.

Por sua articulação com outros discursos, os enunciados constituem réplicas de um diálogo, reveladoras de posições; temos aqui uma de suas peculiaridades: a sua delimitação é dada pela alternância de falantes e torna-se reconhecível no diálogo tal como se conhece. Uma outra peculiaridade dos enunciados, contudo, é que, por ocuparem uma posição 
definida dentro da cadeia verbal (sobre uma questão, um assunto), eles só podem fazê-lo se tal posição for correlacionada a outras posições. Diz Bakhtin (2003, p.297):

Os enunciados não são indiferentes entre si nem se bastam cada um a si mesmo; uns conhecem os outros e se refletem mutuamente uns nos outros. Esses reflexos mútuos lhes determinam o caráter. Cada enunciado é pleno de ecos e ressonâncias de outros enunciados com os quais está ligado pela identidade da esfera de comunicação discursiva. [...] os enunciados dos outros podem ser introduzidos diretamente no contexto do enunciado; podem ser introduzidas somente palavras isoladas ou orações que, neste caso, figurem como representantes de enunciados plenos. [...] os enunciados dos outros podem ser recontados com um variado grau de reassimilação; podemos simplesmente nos basear neles como em um interlocutor bem conhecido, podemos pressupô-los em silêncio, a atitude responsiva pode refletir-se somente na expressão do próprio discurso [...].

E os sentidos vão se aclarando, ao lermos que:

O falante não é um Adão, e por isso o próprio objeto do seu discurso se torna inevitavelmente um palco de encontro com opiniões de interlocutores imediatos (na conversa ou na discussão sobre algum acontecimento do dia-adia) ou com pontos de vista, visões de mundo, correntes, teorias etc. (no campo da comunicação cultural). Uma visão de mundo, uma corrente, um ponto de vista, uma opinião sempre têm uma expressão verbalizada. Tudo isso é discurso do outro (em forma pessoal ou impessoal) e este não pode deixar de refletir-se no enunciado (BAKHTIN, 2003, p.300).

Nesse sentido, articulado a enunciações anteriores e posteriores, os enunciados promovem relações entre si, marcando o caráter dialógico da linguagem em funcionamento. Por isso, o termo diálogo adquire uma conotação mais ampla, englobando qualquer tipo de comunicação verbal, ocorrendo, inclusive, nos atos de leitura. Para Bakhtin, compreender é opor à palavra do locutor uma contrapalavra.

A questão do dialogismo da linguagem, apresentada pela professora Diana Luz Pessoa de Barros, em seu texto "Contribuições de Bakhtin às Teorias do Discurso" (apud BRAIT, 2005a), mostra a dialogia bakhtiniana em duas vertentes: diálogo entre interlocutores e diálogo entre discursos; esta última comporta o dialogismo constitutivo da linguagem e o dialogismo e a polifonia. Já o professor José Luiz Fiorin, em seu livro "Introdução ao Pensamento de Bakhtin" (2006), considera que não se pode fazer tal divisão, visto que o interlocutor é sempre uma resposta, um enunciado.

Para os propósitos do nosso estudo, vamos nos ater às questões, por si bastante complexas, do dialogismo constitutivo da linguagem. Para isso, torna-se necessário refletir sobre a palavra como signo ideológico. 
A palavra é um dos problemas fundamentais da filosofia da linguagem no entender de Bakhtin. Material flexível, veiculável pelo corpo e por ele produzida pelos próprios meios, sem necessidade de aparatos exteriores, a palavra pode ser signo sem expressão externa. Como signo (interior/exterior), ela é carregada de ideologia e, por isso, só pode “aparecer em um terreno interindividual”. E o autor exemplifica (1999, p.35):

[...] não basta colocar face a face dois homo sapiens quaisquer para que os signos se constituam. É fundamental que esses dois indivíduos estejam socialmente organizados, que formem um grupo (uma unidade social): só assim um sistema de signos pode constituir-se. A consciência individual não só nada pode explicar, mas, ao contrário, deve ela própria ser explicada a partir do meio ideológico e social. A consciência individual é um fato sócioideológico.

Dada a palavra como signo social e instrumento da consciência, podemos concebê-la como objeto fundamental do estudo das ideologias. Com efeito, presentes na comunicação humana, nos atos de compreensão e interpretação, possíveis de serem interiorizadas, "as palavras são tecidas a partir de uma multidão de fios ideológicos e servem de trama a todas as relações sociais em todos os domínios". De acordo com Valdemir Miotello, filósofo e doutor em Linguística, em seu artigo sobre Ideologia (2005, p.169), Voloshinov, um dos intelectuais do Círculo de Bakhtin, foi o único a definir ideologia de forma direta e explícita: "Por ideologia entendemos todo o conjunto dos reflexos e das interpretações da realidade social e natural que tem lugar no cérebro do homem e se expressa por meio de palavras [...] ou outras formas sígnicas".

A ideologia comporta, nessa definição, a possibilidade de uma multiplicidade de visões de mundo. Entende-se que, nas várias atividades humanas e nas relações cotidianas, os signos vão se revestindo de sentidos próprios, de acordo com diferentes interesses. Nessa perspectiva, Bakhtin fala em uma ideologia do cotidiano. Nascida de interações sem padrão fixo, em encontros casuais, a ideologia do cotidiano, a princípio sem uma modelagem ideológica clara, estará melhor organizada em estratos superiores quando materializar-se em padrões mais estáveis no interior de grupos organizados, como, por exemplo, um sindicato ou um grupo religioso.

A ideologia do cotidiano não se mantém apartada de uma ideologia oficial na qual, segundo Miotello (2005, p.174),

\footnotetext{
${ }^{1}$ Ibidem, p.41.
} 
[...] circulam os conteúdos ideológicos que passaram por todas as etapas da objetivação social e agora entraram no poderoso sistema ideológico especializado e formalizado da arte, da moral, da religião, do direito, da ciência etc., e portanto já se encontram mais estabilizados, mais aceitos pelo conjunto social, mais testados pelos acontecimentos e mais amparados pelos jogos de poder.

De forma coerente com a ótica bakhtiniana de pensar o mundo, a ideologia do cotidiano é vista como mantendo uma relação dinâmica com a ideologia oficial, com laços mútuos de renovação e refração, imprimindo um caráter de movimento, ideia cara ao pensador russo. Nesse sentido, as palavras são indicadoras de mudanças sociais, mesmo que estas estejam em momentos ainda iniciais e transitórios. Elas tornam-se arenas de vozes sociais. Por isso Bakhtin afirma (1991, p.113) que "toda palavra comporta duas faces", e que “Toda palavra serve de expressão a um em relação ao outro". Assim, a palavra está numa fronteira.

À menção dessas ideias, retomamos o caráter essencial da concepção de linguagem formulada por Bakhtin: há uma dialogia interna na palavra, pois ela está sempre perpassada pela palavra de um outro; ou seja, palavras, como signos, dialogam com signos ou outras palavras. Na dialogia de sentidos, que pode confrontar acordos, divergências, recusas, conciliações, polêmicas etc., colocam-se em relação, tanto interlocutores presencialmente frente a frente (quando as condições de entonação, linguagem gestual e corporal adquirem particular importância), quanto visões de mundo, tendências filosóficas, posições políticas e religiosas. Por isso, a palavra sempre é dirigida a alguém, a um interlocutor, mesmo que este seja um "superdestinatário", ou seja, alguém "cuja compreensão responsiva, vista sempre como correta, é determinante da produção discursiva" (FIORIN, 2006, p.27). Mesmo "o mundo interior e a reflexão de cada indivíduo têm um auditório social próprio bem estabelecido, em cuja atmosfera se constroem suas deduções interiores, suas motivações, apreciações etc.” (BAKHTIN, 1999, p.113).

Dado que o enunciado se constrói tendo em vista uma atitude responsiva, a questão do destinatário ao qual se dirige assume grande importância. Ele pode ser um parceiro de um diálogo cotidiano, uma coletividade de especialistas de um campo cultural, um determinado público, os contemporâneos, os correligionários, adversários e inimigos, um superior, um estranho ou, até mesmo, um "outro" totalmente indefinido etc. Tanto o destinatário quanto a percepção que dele faz aquele que enuncia são constitutivos da formulação do próprio enunciado. Diz Bakhtin²

\footnotetext{
${ }^{2}$ Ibidem, p. 125.
} 
A enunciação realizada é como uma ilha emergindo de um oceano sem limites, o discurso interior. As dimensões e as formas dessa ilha são determinadas pela situação da enunciação e por seu auditório. A situação e o auditório obrigam o discurso interior a realizar-se em uma expressão exterior definida, que se insere diretamente no contexto não verbalizado da vida corrente, e nele se amplia pela ação, pelo gesto ou pela resposta verbal dos outros participantes na situação de enunciação.

Ao falar em discurso interior, Bakhtin remete-nos à questão da consciência e do material semiótico da vida interior - a palavra; a situação do discurso interiorizado é de particular interesse para o nosso estudo, pela condição de enunciação em que se achava Robinson Crusoé. Como já foi mencionado, a palavra produzida pelo próprio corpo pode ser signo sem expressão externa; sendo assim, carregada de ideologia, só tem condição de estar em terreno individual, fazendo da consciência um fato socioideológico.

Na perspectiva bakhtiniana, não se pode, portanto, estabelecer um dualismo entre o conteúdo interior de um psiquismo e sua objetivação exterior. Para o autor russo, a atividade mental não existe sem expressão semiótica e, portanto, junto com a expressão exterior do seu conteúdo, organiza-se um todo em que o centro organizador é exterior àquele que enuncia. Assim, tanto a atividade mental quanto sua exteriorização constituem território social. Enquanto forma de discurso interior, a consciência ainda se encontra em esboço, com raio limitado de ação. Ao se objetivar, torna-se uma força tanto com alcance social como produtora de efeitos sobre a própria atividade mental, estruturando-a de formas mais definidas e estáveis. Assim, de acordo com Bakhtin, não é a expressão que se adapta ao nosso mundo interior, mas o nosso mundo interior que se adapta às possibilidades de nossa expressão. A consciência tem uma existência real e representa um papel na arena do ser. Constituída verbalmente, ela não se situa acima deste ser, mas é uma de suas forças.

A partir do que foi exposto, vemos uma correspondência entre a atividade mental, as enunciações formuladas e o meio extraverbal. Assim, por considerar a palavra como material semiótico, de natureza social, numa concepção essencial das posições teóricas adotadas neste trabalho, descarta-se a possibilidade de compreender os atos de linguagem de Robinson Crusoé como exteriorizações de um conteúdo psíquico de caráter puramente interior.

E como considerar a linguagem literária formulada por Defoe? Ela também se constituiria em um enunciado?

Seria impossível considerar o romance de Defoe apartado da linguagem da vida cotidiana, da realidade concreta. Ele constitui um enunciado, tanto quanto a réplica de um diálogo, mas é dotado de maior complexidade, constituindo um tipo relativamente estável de 
enunciado chamado, por Bakhtin, de gênero do discurso (no caso, um gênero secundário). $\mathrm{O}$ autor diz (2003, p.264):

Os gêneros discursivos secundários (complexos - romances, dramas, pesquisas científicas de toda espécie, os grandes gêneros publicísticos etc.) surgem nas condições de um convívio cultural mais complexo e relativamente muito desenvolvido e organizado (predominantemente o escrito) - artístico, científico, sociopolítico etc. [...] gêneros primários, que integram os complexos, aí se transformam e adquirem um caráter especial: perdem o vínculo imediato com a realidade concreta e os enunciados reais alheios: por exemplo, a réplica do diálogo cotidiano ou da carta no romance, ao manterem sua forma e o significado cotidiano apenas no plano do conteúdo romanesco integram a realidade concreta apenas através do conjunto do romance, ou seja, como acontecimento artístico-literário e não da vida cotidiana.

Assim, mudanças históricas dos estilos de linguagem ligam-se às mudanças dos gêneros do discurso, o que mostra a relação entre a história da sociedade e da linguagem.

Como enunciado, a obra tem uma intenção discursiva (que se concretizará em um gênero escolhido) e busca uma compreensão responsiva que pode assumir diferentes formas: uma influência educativa sobre os leitores e suas convicções, sobre seguidores, continuadores, críticas. Ela também se constitui um elo na cadeia discursiva. De acordo com Bakhtin, cada época, cada corrente literária, cada gênero literário apresenta concepções específicas dos destinatários das obras literárias.

Em se tratando do romance, ele é revelador de diferentes discursos existentes na sociedade e que podem aparecer veiculados por diferentes personagens, por uma mesma personagem ou pelo narrador e pelas personagens. Segundo Fiorin (2005, p.232-233), a historicidade do romance não é dada pelos fatos históricos e nem por uma relação de oposição entre discursos (exemplifica com discurso proletário versus burguês), mas pela revelação “dos espaços discursivos de uma formação social”’3. Neste momento, retomamos Bakhtin, ao dizer que não se deve "fechar" uma obra literária em sua época de criação, em sua atualidade, pois ela tem raízes num passado distante. No caso das grandes obras, como é "Robinson Crusoé", elas são preparadas por séculos. Se tentarmos entendê-las somente a partir do seu momento de criação, estaremos distantes de seus sentidos mais profundos.

Onde há linguagem, há dialogia. Com base nessa ideia de Bakhtin, a análise do discurso de linha francesa fala em heterogeneidade constitutiva do discurso, ou seja, todos os

\footnotetext{
${ }^{3}$ A noção de espaços discursivos é tomada de Maingueneau: são subconjuntos de formações discursivas que estão em relação pertinente para os propósitos da análise. Formação discursiva é um sistema de coerções da boa formação semântica de um dado discurso.
} 
discursos são atravessados por outros. Maingueneau, autor já citado neste trabalho, e AuthierRevuz encontram-se entre os estudiosos dessa abordagem.

No caso da obra literária que agora é foco de nosso estudo, podemos ir em busca da dialogia, da heterogeneidade, investigando as marcas explícitas que delimitam as alternâncias de falantes pelo uso de formas composicionais do enunciado, que tornam visíveis as vozes envolvidas. Tais formas, pelas quais as vozes do Outro adquirem concretude num enunciado, podem ser a do discurso objetivado, da citação direta, como por exemplo, o uso de aspas ou pela bivocalidade, sem uma separação muito nítida entre elas, como é o caso de uma paródia.

Outra possibilidade de apreensão lidará com a dialogia interna da palavra, com uma heterogeneidade não mostrada, possível de ser buscada pela procura das relações entre os discursos em que não há marcações e que não se mostram facilmente.

A questão da dialogia da linguagem apresentou-se aos estudos desta pesquisa pela leitura das obras do Círculo de Bakhtin. Isto ensejou uma pergunta: teriam sido esses intelectuais russos os primeiros a formularem essa concepção?

Edward Lopes, em seu texto "Discurso Literário e Dialogismo em Bakhtin" (2003), traz esclarecimentos sobre o assunto, citando Boris Schnaiderman, estudioso e tradutor das obras do pensador russo (p.80):

É preciso reconhecer (que) ninguém elaborou esse tema (do dialogismo) com a mesma riqueza e profundidade (que Bakhtin), mas também é preciso render justiça aos (autores) que ele omite ou aos quais se refere com evidente má-vontade" (SCHNAIDERMAN,1979, p.24 apud LOPES, 2003, p.70).

Estabelecidas de uma forma breve, que buscou trazer alguns elementos do arcabouço teórico de Bakhtin e que se pretendeu cuidadosa na tentativa de não reduzi-lo ou simplificá-lo, as posições apresentadas permitem-nos não levar em conta também a proposta de entender as falas de Robinson Crusoé como formas linguísticas descontextualizadas, ahistóricas e desvinculadas de um fluxo de comunicação verbal. Entendemos linguagem, sociedade e história como integrantes de uma unidade.

A partir do postulado de que os atos de linguagem de Robinson Crusoé têm natureza social, são atos produtores de enunciados (em que podem ser identificadas outras vozes, dada a natureza dialógica da linguagem), como entender o personagem dentro de um paradigma de individualidade? A individualidade do personagem estaria expressa em suas ações concretas e solitárias, de intervenção no meio ambiente e desvinculadas de seus atos 
simbólicos? Não acreditamos ser possível admitir tal hipótese, pois é inadmissível dicotomizar a vida humana em ações concretas e formas simbólicas.

Como estabelecer relações entre uma indagação crucial, que admite a natureza social e vai de encontro a uma das visões mais difundidas deste personagem da literatura clássica (a solidão), e as possibilidades de reflexão fornecidas pelo pensamento de Bakhtin e seu círculo de intelectuais?

O encaminhamento dos estudos e pesquisas permite aclarar esta indagação por meio de um excerto de Bakhtin, em parte já citado anteriormente (2003, p.363-366):

A vida das grandes obras nas épocas futuras e distantes, como já afirmei, parece um paradoxo. No processo de sua vida post mortem elas se enriquecem com novos significados, novos sentidos; [...] Outrora Bielinski já dizia que cada época sempre descobre algo de novo nas grandes obras do passado. Pois bem, introduzimos nas obras de Shakespeare coisas inventadas que não havia nelas, modernizamos e deturpamos o próprio? É claro que houve e haverá modernizações e deturpações. Contudo, não foi à custa delas que Shakespeare cresceu. Ele cresceu à custa daquilo que realmente houve e há em suas obras, mas que nem ele nem seus contemporâneos foram capazes de perceber conscientemente e avaliar no contexto da cultura de sua época.[...]

Contudo, a cultura de uma época, por mais distante que esta esteja de nós no tempo, também não pode ser fechada em si mesma como algo pronto, plenamente acabado, que se foi de uma vez por todas, morto [...] a unidade de uma cultura é uma unidade aberta.[...]

No campo da cultura, a distância é a alavanca mais poderosa da compreensão.

A distância permite-nos apelar para este pensador das primeiras décadas do século XX, marxista, que viveu na Rússia stalinista e foi perseguido, a fim de nos fornecer outra possibilidade para pensarmos a questão da individualidade.

Bakhtin estabelece uma distinção entre o conceito de um indivíduo natural isolado, sem associações com o mundo social e o conceito de individualidade. Este último constitui, em sua concepção, uma "superestrutura ideológica semiótica que se coloca acima do indivíduo natural e é, por conseqüência, social” (1999, p.58).

Trabalhando de forma entrelaçada com os conceitos de psiquismo e ideologia, individual e social, o autor aponta que todo produto da ideologia traz a marca da individualidade de seus criadores; contudo, ela é, em si mesma, social. E conclui: “Assim, todo signo, inclusive o da individualidade, é social" ${ }^{\text {. }}$. Ele afirma que, mesmo se considerando a especificidade do psiquismo, este não é incompatível com uma concepção ideológica e sociológica a ser-lhe atribuída. Dessa maneira, Bakhtin entende que não é da personalidade

\footnotetext{
${ }^{4}$ Ibidem, p.59.
} 
que se tira a confiança individualista em si, mas do exterior: é quando se explicita um status social, uma posição econômica. E diz: "Assim, a personalidade que se exprime, apreendida, por assim dizer, do interior, revela-se um produto total de inter-relação social"5.

$\mathrm{O}$ encontro entre a concepção dialógica da linguagem desenvolvida por Bakhtin e a solidão de Robinson Crusoé mostra-se campo de pesquisa privilegiado para possibilitar tanto a verificação do pulsar da dialogia nos atos de linguagem de um solitário, quanto uma possível presença de marcas sociais nesses mesmos atos, existentes na ausência do convívio humano.

A partir do trabalho de análise, será possível confirmar ou descartar a hipótese formulada.

\section{APREENSÃO DE ENUNCIADOS E DISCURSOS: PASSOS METODOLÓGICOS}

O conhecimento das propostas de Bakhtin para estudo do funcionamento real da linguagem é de fundamental importância para a compreensão da busca dos enunciados e discursos de Robinson. Se a própria teoria nos aponta o artificialismo de isolar os atos de linguagem, ela mesma também nos dirige para o passo seguinte da pesquisa - reintegrá-los à obra a partir das seguintes perguntas feitas a cada um deles:

- Qual o contexto extraverbal que o engendrou?

- A quem Robinson pergunta ou responde?

- A que discursos seus enunciados remetem?

O encaminhamento de respostas exigiu leituras sobre a história da Inglaterra e o século XVIII, em suas posturas filosóficas e culturais (com atenção ao campo da linguagem), como forma de estabelecer relações entre enunciados.

As respostas obtidas às questões formuladas permitiram categorizar os atos de linguagem em:

- Pensamentos;

- Perguntas;

- Invocações;

\footnotetext{
${ }^{5}$ Ibidem, p.117.
} 
- Busca de interlocutores;

- Exercício de imaginação;

- Expressão de experiência e reflexões.

Este trabalho permitiu fazer aflorar os discursos interiores de Robinson, sua procura por interlocutores, expressão exterior de enunciados, atos de leitura e escrita, em que se buscaram indícios de interdiscursividade, ou seja, de representações da palavra do Outro. Dado que a força do seu relato tem sido firmada pelas ações de domínio da natureza e satisfação de necessidades materiais - a princípio de subsistência e, depois, de alguns confortos - foi por meio de um "zoom" de ampliação de seus enunciados que evidenciamos a presença constante e a força da linguagem em sua vida.

No corpo do trabalho não são transcritos todos os enunciados (explicitados no Anexo C). Contudo, a apresentação de toda a listagem feita permitirá ao leitor uma maior clareza das situações de fala encontradas, embora, evidentemente, a compreensão, possível pelo conhecimento do naufrágio e do isolamento na ilha, fique solapada, em alguns pontos, pela supressão do contexto imediato da enunciação.

Além disso, foi a seleção minuciosa e a transcrição dos vários enunciados que possibilitou ver Robinson dentro do movimento da linguagem, seus atos de reflexão e construção de experiências, criando condições de aferição da hipótese formulada.

Embora o foco do trabalho tenha abordado, primordialmente, o tempo de ausência total de convívio humano por parte do náufrago, foram procuradas, no discurso de Defoe, algumas marcas dos tempos e das culturas que se entrelaçam como discursos, como forma de identificar, também no relato biográfico, o caráter dialógico da linguagem.

Reflexões sobre a obra e leituras teóricas se retroalimentaram.

Pela complexidade da leitura e compreensão dos estudos bakhtinianos, estudiosos que a ela se dedicaram foram buscados em suas compreensões responsivas. Foram eles: José Luiz Fiorin, Diana Luz Pessoa de Barros, Beth Brait, Carlos Alberto Faraco, Marília Amorim, Valdemir Miotello.

Outros autores também foram requisitados: Todorov, que sistematizou o pensamento de Bakhtin no Ocidente, Roland Barthes, Michel de Certeau, Authier-Revuez, Dominique Maingueneau, Albert Manguel, Zygmunt Bauman, Ivonne Bordelois.

Sobre questões de escrita e materialidade da obra, estivemos com David Olson e Roger Chartier. Em questões de "Práticas de devoção" e "Discursos literários", Jean-Marie Goulemot e François Lebrun. 
$\mathrm{Na}$ apresentação dos atos de linguagem de Robinson no corpo do trabalho, foram utilizadas diferentes fontes (tipos/cores de letras) a fim de diferenciar as escritas - os enunciados de Robinson na ilha, os enunciados do seu relato autobiográfico e os enunciados bíblicos.

As reflexões elaboradas a partir dessas sucessivas leituras foram dirigidas para a hipótese formulada, com vistas a um ato de compreensão e com a intenção de explorar sentidos múltiplos da obra. Pelo fato de nos colocarmos dentro de uma cadeia discursiva, os percursos dos enunciados (de Robinson na ilha e como narrador da experiência, de Defoe, dos autores apresentados e da pesquisadora) encontram-se e reencontram-se em vários momentos, trazendo certa repetitividade no estabelecimento de relações e explicações. Esta, contudo, é intencional, na medida em que colore a fluidez, encontros, desencontros e riquezas da linguagem em funcionamento.

$\mathrm{Na}$ tentativa de caminhar junto a propostas de Bakhtin quanto à pesquisa em Ciências Humanas, buscamos efetuar os estudos feitos numa perspectiva cultural, de modo a construir sentidos para o presente. Toca-nos, de forma particular, o que o autor fala sobre os estudos literários em seu país, em resposta a uma pergunta da revista Novi Mir (não é expresso o ano em que foi realizada) ${ }^{6}$. Ele diz que "domina um certo temor de risco investigatório, um temor de levantar hipóteses [...] e o temor de levantar hipóteses ousadas acarretam necessariamente o domínio de truísmos e chavões" (2003, p.360). E termina o texto dizendo que, sem ousadia, não podemos nem ir às alturas e nem descer às profundezas.

Consideramos que esta fala do autor aponta para um sério perigo, do qual devemos fugir pelo enfrentamento.

Nosso propósito, ao tentar buscar uma compreensão criadora, foi mobilizar um esforço, com a certeza de estar muito, muito longe do que o autor efetivamente propõe, mas com o desejo de sinalizar a necessidade de movimentos em direção a novos desafios.

\footnotetext{
${ }^{6}$ O texto intitula-se "Os Estudos Literários Hoje" e encontra-se no livro "Estética da Criação Verbal". São Paulo: Martins Fontes, 2003.
} 



\section{Pante 3}





\section{ROBINSON CRUSOÉ: A DIALOGIA DA LINGUAGEM NA ILHA DO DESESPERO}

\section{ATIVIDADE MENTAL, ENUNCIAÇÕES E MEIO EXTRAVERBAL}

Nascido em uma ilha do Velho Mundo, onde se gestava um sistema capitalista e da qual se afasta por longos anos, Robinson torna-se um explorador de uma outra ilha, desconhecida e deserta, no chamado Novo Mundo, ainda envolto em histórias de exotismo e selvagerias; um caminhante a descobrir e descobrir-se em escritas de novos espaços geográficos e escritas de si mesmo.

Acompanhamos Robinson em suas andanças, atividades, sucessos e insucessos da vida cotidiana, atos que têm atraído maior atenção em seu relato autobiográfico. Contudo, há algo que consideramos intrigante e nos é dito pelo próprio Robinson: “[...] Mas devo primeiro falar um pouco de mim e dos meus pensamentos acerca da vida, que se pode supor não seriam poucos [...]” (p.66).

Realmente, Robinson discutia consigo mesmo, formulava perguntas e respondia a si próprio, recriminava-se, refletia, fazia especulações, ou seja, tinha uma intensa atividade mental. No vigésimo quarto ano de sua permanência na ilha, numa noite de insônia, ele faz uma revisão de toda a história de vida - "é tão impossível como inútil indicar a infinidade de pensamentos que passaram por esta grande avenida do cérebro que é a memória” (p.188).

Caminhar com os pensamentos de Robinson alimentados pela concepção dialógica da linguagem é tentar vê-los em suas relações de sentidos, é tentar buscar a palavra do Outro, vendo-os como constituídos e constituintes dos próprios enunciados e, também, do meio extraverbal. É o que tentaremos fazer, num desafio que se soma ao da elaboração de um texto que dê conta de tal complexidade. 
"A interação verbal constitui a unidade fundamental da língua"

Bakhtin

\section{Porquê [sic] me tinha Deus feito isto? Que tinha eu feito para ser assim} tratado? (p.95).

"Pode Deus pôr uma mesa no descampado?" e, assim, comecei a dizer; "Pode Deus livrar-me deste lugar?” (p.97, grifos nossos).

Como conceber estes enunciados de Robinson? Que situação extraverbal está aí implicada? Quem era seu interlocutor, com quem interagia verbalmente?

Robinson está sozinho numa ilha deserta, sobrevivente de um naufrágio, isolado de tudo e de todos; não atendera aos conselhos de seu pai para não se meter em aventuras pelo mar, e castigos divinos estariam reservados em caso de desobediência. Suas enunciações, portanto, engendram-se desta - e na - situação específica e remetem a um contexto maior, anterior, que as ligam a situações passadas e também a outros sujeitos, discursos e enunciados. Retomando Bakhtin (apud BRAIT; MELO, 2005b, p.67):

A característica distintiva dos enunciados concretos consiste precisamente no fato de que eles estabelecem uma miríade de conexões com o contexto extraverbal da vida, e, uma vez separados deste contexto, perdem quase toda a sua significação - uma pessoa ignorante do contexto pragmático imediato não compreenderá estes enunciados.

Vivendo uma situação-limite, Robinson entrega-se a solilóquios, em que o verbal e o não verbal integram-se na formulação de seus enunciados. Desde os primeiros momentos, em fase de reconhecimento do local e busca de materiais no navio destruído, pensa em opções para resolver seus problemas imediatos. Mas, imerso na difícil situação, “Comecei a pensar que devia trazer muitas coisas do barco [...] então reuni o conselho, quer dizer, no meu pensamento, se devia levar a jangada [...] (p.58, grifo nosso).

A que conselho pode estar se referindo? Não pede conselho sobre o que fazer, mas reúne o conselho. A palavra carrega, aqui, sentidos que remetem aos discursos e experiências que Robinson traz interiorizados - critérios de utilidade das coisas, especialmente na situação de vida que se lhe apresentava, a experiência de outros naufrágios com a destruição total do navio, a experiência de ter construído uma primeira jangada para transporte de suas "utilidades" - provisões, roupas, ferramentas, munições. 
Robinson sabe que responde a si mesmo, pois diante dessas perguntas (Porquêe [sic] me tinha Deus feito isto? Que tinha eu feito para ser assim tratado?), diz que lhe responde a voz de sua consciência:

\begin{abstract}
A minha consciência atacou-me nesta pergunta como se tivesse blasfemado, e pareceu-me que me falou como se fosse uma voz exterior: "MISERÁVEL!, perguntas o que fizeste? Olha para trás, nessa vida mal gasta, e pergunta o que não fizeste; pergunta: 'Porque [sic] não fui ainda destruído? Porque é que não me afoguei em Yarmouth, não pereci na luta quando o barco foi tomado pelos piratas de Sallee, devorado pelas feras na costa da África ou afogado aqui, quando toda a tripulação morreu, menos tu?'E perguntas: 'Que fiz eu?'”' (p.95, grifo nosso).
\end{abstract}

A resposta formulada também remete a novos discursos: as dificuldades enfrentadas pelo jovem em suas aventuras pelo mar, a pirataria nos oceanos e o comércio africano de escravos para sustentar plantações em terras americanas. E ao mencionar uma vida mal gasta, novamente faz ecoar o discurso do pai de Robinson, contrário à vida de aventuras desejada pelo filho e a favor da estabilidade e segurança proporcionadas pela vida de um estrato social médio (discurso que não é individual, mas que se liga a um ponto de vista social, ideológico). Discurso cotidiano, de um pai a seu filho, carregado de uma ideologia que assentava raízes numa ilha europeia, tão diferente da Ilha do Desespero de Robinson. Uma ideologia de cotidiano contestatória de valores atrelados à nobreza de nascimento e sustentadora de valores de uma burguesia nascente, capitalista e colonizadora. Uma burguesia para a qual ilhas distantes poderiam ser fonte de matérias-primas e lucros. E, na ideologia do cotidiano, a palavra mostra-se portadora e prenhe de tais sentidos, como podemos constatar nas palavras iniciais do relato da história de Robinson Kreutznaer.

Narrada em primeira pessoa, plena de detalhes que lhe dão o tom de relato realista, as palavras marcam o nascimento e a origem de um jovem personagem enraizado histórica e socialmente. Como já foi dito, nascemos duas vezes, para a vida e para a cultura. Sem um "pré-nome", Robinson Kreutznaer representa, na verdade, a junção dos sobrenomes dos pais, o primeiro de origem nobre, o segundo burguês, chegado à Inglaterra como estrangeiro em busca de negócios. Mas quem conhece a história de Robinson Kreutznaer? Validado pelo grupo, o sobrenome do pai acabou transformando-se e incorporando-se à história como todos a conhecem - as aventuras de Robinson Crusoé. Diz Robinson no início de seu relato autobiográfico: 
[...] por isso o meu apelido era Robinson Kreutznaer; mas devido às habituais corruptelas das palavras em Inglaterra, somos agora chamados, ou, melhor, chamamo-nos a nós próprios e escrevemos o nosso nome, Crusoé, e os meus companheiros sempre assim me chamaram (p.11).

Chamar-se e ser chamado são duas faces da nomeação, apontam a interação entre interlocutores, mostram a linguagem em funcionamento. A palavra/nome/signo, validada socialmente, registrou fases transitórias de mudanças sociais.

Mas como considerar a palavra enquanto signo interior, formulando a pergunta para o próprio Robinson - "Que tinha eu feito para ser assim tratado?”.

Ela soa como blasfêmia, e é respondida com a dureza de um adjetivo pejorativo -

\section{"MISERÁVEL!".}

Impressa em letras maiúsculas e com sinal de exclamação, tal forma e conteúdo buscam exprimir uma entoação de acusação e desprezo. Uma só palavra que, sozinha, poderia se constituir num enunciado com elemento expressivo e com caráter valorativo, mas que se apresenta constituinte de um enunciado/expressão da consciência falante. Uma atitude responsiva com expressões duras, que responde ao que Robinson vem a considerar, mais tarde, seu pecado original. Nesse sentido, Bakhtin diz sobre o enunciado concreto: "Sua forma e significado são determinados basicamente pela forma e caráter desta interação" (apud BRAIT; MELO, 2005b, p.68). Pecador e miserável, Robinson dialoga com sua consciência, verbalmente constituída, e que se reporta à imagem do homem subordinado ao poder de Deus.

A questão do discurso interior na vida do náufrago solitário remete-nos à condição da palavra como material semiótico do psiquismo, base da vida interior. Para abordá-la, transcrevemos as primeiras palavras de Robinson Crusoé em sua narrativa - "Nasci no ano de 1632, na cidade de Iorque [...]” -, com as quais ele se ancora num meio social específico, ideológico. Logo após as considerações a respeito de sua família, Robinson discorre sobre as discussões acontecidas em casa a respeito de seus projetos de viagens, momentos em que se evidenciam os valores ideológicos familiares. Essa situação inicial do relato é indicadora de que a palavra é o signo privilegiado na comunicação da vida cotidiana. Por ser material flexível, veiculável pelo corpo, sem necessidade de apelo a recursos, aparelhagens ou material extracorporal, a palavra torna-se signo interior, podendo funcionar sem expressão externa. Mas, considerando o signo como fenômeno do mundo exterior, temos que a consciência individual, repleta de signos, forma-se no processo de interação social, ou seja, a consciência individual é um fato socioideológico. Diz Bakhtin (1999, p.35-36): 
A consciência adquire forma e existência nos signos criados por um grupo organizado no curso de suas relações sociais. Os signos são o alimento da consciência individual, a matéria de seu desenvolvimento, e ela reflete sua lógica e suas leis.

A partir disso, podemos perguntar de que forma considerar os signos interiores como objeto de estudo em nossas questões de linguagem. O referido autor nos responde: "Em sua forma pura, o signo interior, isto é, a atividade mental, é acessível apenas à introspecção" (1999, p.61); e adverte, afirmando que, contudo, é preciso compreender corretamente a natureza do psiquismo e da própria introspecção.

O autor considera que o objeto da introspecção é o signo interior, que pode ser exteriorizado. Assim, a "própria introspecção é dotada de um caráter expressivo [...] [e] constitui um ato de compreensão"1.

Buscando compreender e, ao mesmo tempo, expressando-se, Robinson, muitas vezes, falava em voz alta, ao fazer perguntas:

\footnotetext{
"[...] disse em voz alta (se bem que para mim), o que teria feito sem uma arma, sem munições, sem nenhuma ferramenta para fazer qualquer coisa, ou para trabalhar, sem roupas, colchões, barraca ou qualquer coisa para me cobrir?" (p.67).
}

Gritava, ao invocar: "Então gritei: "Deus, ajuda-me, porque estou em grande aflição!” (p.94, grifo nosso).

E conjugava, às suas palavras, outros gestos ou manifestações expressivas do organismo:

\begin{abstract}
"Ah, se ao menos estivesse aqui um ou dois [...] que falasse comigo e com quem eu pudesse conversar também!” [...] E a minha ânsia era tal que, quando proferia estas palavras, as minhas mãos se enclavinhavam e os meus dedos premiam as palmas das mãos de tal forma que, se tivesse algo mole na mão, tê-lo-ia esmagado involuntariamente (p.181-182, grifo nosso).
\end{abstract}

As enunciações transcritas acima ligam-se estreitamente à situação enfrentada por Robinson, sendo elas tanto exteriorizações de seu mundo interior como constituintes da sua experiência na ilha; mostram que a "introspecção se esforça por explicitar ativamente o signo interior, para levá-lo a um maior grau de clareza semiótica” (Bakhtin, 1999, p.62). Dessa forma, podemos perceber como a introspecção se encontra integrada na experiência objetiva, corporal, sendo impossível dissociá-la de uma observação exterior, separar os signos interiores e exteriores que a constituem e abstraí-los da situação social em que se integram.

\footnotetext{
${ }^{1}$ Ibidem, p.61.
} 
Experiências de denso teor disparam torrentes de enunciação por parte de Robinson. Assim, a visão repentina da marca de um pé humano leva-o a alterar a forma como chamava sua habitação - de casa, para castelo, local onde iria se refugiar - "enfiei-me nele como alguém perseguido” (p.152). O uso de uma nova palavra fez-se na emergência de uma nova situação: senhor da ilha, "tinha as vidas de todos os meus súbditos à minha absoluta disposição” (p.146), Robinson teve de se refugiar-se em uma fortificação, à semelhança dos nobres em seus feudos medievais diante de ameaças externas. $\mathrm{O}$ fato disparou imagens em sua mente; ao voltar para o seu reduto, logo após a terrível visão, imagina que "todos os troncos ao longe eram homens" (p.152), que o Diabo fazia-se presente na ilha. Perguntas foram formuladas: por que haveria outra coisa com forma humana de vir à ilha? Onde estava o barco que os havia trazido? Como havia só aquela marca? Como é que era possível um homem vir até ali?

Que relação Robinson poderia ter feito entre a marca de um pé humano e o demônio?

Havia a possibilidade de Satã ter tomado forma de homem, visto ser um ente dissimulado. Com efeito, a marca impressa causava efeitos devastadores, virava seu mundo de cabeça para baixo, deixava-o fora de si, tal como uma ação do demônio poderia provocar. Mas, valendo-se de sua lógica racional, Robinson "ri”" dessa possível estratégia demoníaca, pois o lugar em que se encontrava a marca era distante do ponto em que ele morava e o vento e o mar poderiam apagá-la (o demônio não era um ser ingênuo). Abandonando essa possibilidade, volta-se para outra explicação, não menos assustadora - a marca do pé seria de um canibal:

[...] eu sentia uma repulsa tão grande por estes miseráveis selvagens [...] e do vil e desumano costume de se devorarem uns aos outros [...] a aversão que tinha a esses miseráveis diabólicos, e tinha mais receio de ver um deles do que o Diabo propriamente dito (p.162).

O terror desvia Robinson do planejamento de suas atividades e ativa planos para a destruição dos selvagens. Mas, novamente, forma-se um encadeamento de questões:

Que autoridade tinha eu para pretender ser juiz e executor destes homens como criminosos, homens que os Céus tinham resolvido manter impunes durante várias gerações e fazer deles, ao fim e ao cabo, os executores dos Seus desígnios? Em que medida, eram eles réus, perante mim? E que direito tinha eu de intervir nesta querela, em que o sangue era vertido por eles? Debati várias vezes comigo mesmo o seguinte: como é que eu sabia o que Deus julgava deste caso particular? (p.167). 
As indagações de Robinson, ao mesmo tempo em que invalidam sua posição de juiz, trazem consigo várias vozes sociais, ideológicas, a respeito dos selvagens: ora vistos como assassinos, ora como portadores de uma natureza canibalista, executores de vontade divina, ou isentos de culpa perante cristãos matadores, ora inconscientes de suas atitudes criminosas. Seus questionamentos carregam a ideia de justiça pela qual refutam a forma da colonização espanhola na América - em que houve dizimação das populações nativas - com extrema perversidade. A esse respeito, o próprio Robinson exemplifica, para nós, o fato de a palavra ser signo social dizendo: “[...] a palavra 'espanhol' é considerada terrivel $e$ assustadora para toda a humanidade e para os cristãos [...]” (p.168). O enunciado remete às relações estabelecidas entre Inglaterra/Holanda, na situação de guerra ocorrida entre Holanda e Espanha, fato ao qual Robinson alude no início de seu relato, ao falar da morte do irmão em combate. Mas também é Robinson quem diz (p.190):

Quando acabei de pensar nisto, o meu espírito passou a dedicar-se à natureza destas miseráveis criaturas, quero dizer, os selvagens, e como é que era possível acontecer no mundo que o sábio Governador de todas as coisas pudesse dar a algumas das Suas criaturas tanta desumanidade.

Reconhecendo-se em erro pelo desejo de eliminá-los, pois se surpreendera com a “desumanidade, a brutalidade infernal e o horror da degenerescência humana", o náufrago termina por concluir (p.201):

Mas eu dava por findos os meus pensamentos, confrontando-os com estas
conclusões: (primeira) que nós não sabíamos sob que ponto de vista e em
relação a que lei é que isto podia ser condenado [...] devia ser por causa de
terem pecado contra essa luz [...] e, (segunda), como todos nós éramos o
barro nas mãos do oleiro, nenhum pote poderia dizer-lhe: 'Porque é que vós
me fizestes assim?'.

As situações apontadas mostram que, quer trate-se de discurso interior (diálogo consigo mesmo), quer exterior, as enunciações têm uma natureza social. Há sempre um interlocutor, ao menos em potencial, pois o locutor pensa e se exprime para um auditório social bem definido. Em outras palavras, todo enunciado é dialógico, ou seja, constitui-se a partir de outros enunciados.

Nessa perspectiva, a quem Robinson responde, estando sozinho na ilha?

Robinson responde a enunciados que lhe estão interiorizados; mas isso não lhe é suficiente. Ele ansiava por um interlocutor real a quem pudesse dirigir seu discurso. Um Outro para quem sua palavra se dirigisse, formando uma ponte, dado o fato de que a ausência de resposta é intolerável para o ser humano. Não podendo, facilmente, lidar com a falta física 
do Outro da linguagem, principalmente nos primeiros anos de sua solidão, ele falou com elementos concretos, dirigiu-se a objetos e à natureza, humanizando-os.

Assim, ao buscar despojos no navio em destroços, mas ainda encalhado próximo à praia, Robinson encontra "trinta e seis libras, parte em moeda espanhola, parte em brasileira, algumas peças de oito, algum ouro e prata” (p.61), e diz (p.61-62, grifo nosso):

À vista deste dinheiro, sorri para mim mesmo. 'Porcaria,' disse em voz alta. "que utilidade tens? Embora valioso, para mim não vales o trabalho de me baixar para te apanhar; uma destas facas vale mais do que todas estas moedas; não tenho forma de te dar uso, por isso fica aí, se bem que valioso, e vai para o fundo como animal cuja vida não vale a pena salvar”.

Como filho do nascente capitalismo inglês, Robinson reconhecia a validade do dinheiro. Comerciante, dono de engenho em terras brasileiras, enriquecido por transações, como poderia negá-la? No entanto, de que lhe serviria no momento? É preciso lembrar que metais acumulados, tratados como índice da riqueza de uma nação dentro de uma política mercantilista, tornaram-se, posteriormente, produtos de troca, como qualquer outro (segundo Watt [1997], Defoe partilhava de ideias mercantilistas, já abandonadas). Entre o valor trazido da sociedade a que pertencia e o contexto imediato, Robinson elabora seu enunciado "[...] que utilidade tens? Embora valioso ...”, tentando humanizar o inanimado.

Retornando à ilha, após uma dessas incursões à embarcação, e preocupado com alguma presença devoradora de suas provisões, ele não encontra "sinal de visitante algum" somente (p.59)

[...] estava em cima de uma das arcas um animal semelhante a um gato selvagem, o qual, quando me aproximei dele, fugiu para perto e ficou quieto; ficou muito quieto e indiferente, e olhava-me directamente para a cara, como se pensasse em travar conhecimento comigo.[...] the dei um bocadinho de biscoito, embora não tivesse muito, [...] ele aproximou-se, cheirou-o, comeu-o e procurou (como que agradado) mais, mas eu agradeci-lhe [...].

Após cinco anos na ilha, Robinson decide circunavegá-la. Munido de um barco menor do que um outro já construído, lança-se à viagem, mas uma corrente marítima leva-o a tal iminência de afastamento da costa (com o risco de perecer de fome), que ele toma consciência de que sua situação poderia ficar pior do que era. Olhando, de longe, para sua ilha desolada e solitária, anseia pela volta e dirige, a ela, o enunciado: “Oh, deserto feliz, nãa mais te verei! (p.138, grifo nosso), numa alusão à iminência da morte e à lembrança dos tempos vividos em terra firme. 
A ânsia por interlocutores era tal que Robinson dedica-se alguns anos a ensinar um papagaio, que ele nomeia Poll, a pronunciar palavras:

Vi uma grande quantidade de papagaios e pensei que deveria apanhar um e criá-lo, para o domesticar e ensinar-lhe a falar-me. [...] trouxe-o para casa, mas foi muito antes de o conseguir fazer falar; contudo, por fim, consegui fazê-lo chamar-me pelo nome, duma forma perceptivel (p.110).

[...] enquanto estava a trabalhar me distraía falando com o meu papagaio e ensinando-o a falar, depressa conseguindo que ele conhecesse o seu nome e por fim o dissesse, bem explícito, POLL, que foi a primeira palavra que ouvi nesta ilha dita por alguém que não eu (p.120).

Ensinar o papagaio a falar tem implicações na vida do personagem, na medida em que, estando adormecido em certa região da ilha, após ter se salvado de sucumbir no meio de uma correnteza, Robinson sente-se surpreendido e assustado ao ouvir ser chamado (p.141142):

[...] fui acordado por uma voz chamando-me pelo meu nome várias vezes: 'Robin, Robin, Robin Crusoé, pobre Robin Crusoé, onde estás, Robin Crusoé? Onde estás? Onde estiveste?'

[...]

[...] pensei ter sonhado com alguém a falar comigo, mas, como a voz continuava a repetir: 'Robin Crusoé, Robin Crusoé'[...]

[...]

Mas, mal abri os olhos, vi o meu papagaio Poll empoleirado no topo da cerca, imediatamente percebi que era ele que me tinha falado [...]

[...]

'Pobre Robin Crusoé, onde estás? Onde estiveste? Como chegaste aqui?' e outras coisas semelhantes que eu the ensinei.

[...]

Tinha a certeza de que não podia ser ninguém além do honesto Poll [...] e continuou a falar-me: 'Pobre Robin Crusoé! Como vieste? Onde estiveste?' tal como se estivesse transbordante de alegria por me voltar a ver [...].

Os sons ouvidos remeteram Robinson à possibilidade de um sonho em que alguém lhe falava, mas, despertando, reconheceu a voz lamuriosa que tinha usado para falar e ensinar palavras a Poll. A repetição de palavras e modulações inseriram-se em um contexto em que se faziam apropriadas para um frustrado Robinson, criando possibilidades de sentidos para quem almejava, ardentemente, um semelhante com quem interagir.

Nas condições em que se apresentavam os enunciados de Robinson acima descritos, com objetos e animais, não podemos caracterizá-los como atos de interação verbal, visto não ter sido constituída uma situação com dois falantes, pertencentes à mesma comunidade linguística e a uma sociedade claramente organizada. Além disso, mesmo se tratando do caso de Poll, havia, de um lado, um locutor, e, de outro, um emissor de sons, reprodutor de fenômenos puramente acústicos, sem valor ideológico, semiótico, ou social. 
Isso evidencia a grande lacuna na vida do personagem, pois, ao ensinar a Poll as perguntas que lhe são dirigidas, Robinson buscava preencher vazios de linguagem em sua existência, em sua busca da palavra do Outro, de um Outro que o chamasse e com quem dialogasse. A tal ponto a possibilidade de articular sons por parte de Poll era importante para Robinson, que o animal adquire uma condição privilegiada no seio do que ele chama de sua “pequena família e criadagem” (Não disse Deus, no Salmo 68 6, que Deus faz o solitário morar em família?). Vejamos:

[...] deste tempo, muito foi gasto no terrível trabalho de fazer uma gaiola para o meu Poll, que começava a ser um simples doméstico e a ficar muito bem relacionado comigo (p.112).

[...]

Daria um sorriso estóico, ter-me visto à mesa, com a minha pequena família, sentados a jantar (p.146).

$[\ldots]$ Como um rei, comia sozinho servido pelos meus criados. Poll [..] era a única pessoa autorizada a falar comigo (p.146).

É importante esclarecer que, ao falarmos em enunciações de Robinson diante de objetos ou seres inumanos, estamos considerando as relações de sentido destas enunciações com outros discursos, alheios à consciência de Robinson naquele momento. A própria dialogia da linguagem vibrava "ondas crescentes de ecos e ressonâncias verbais", trazendo Outros à ilha deserta, povoando-a de vozes inaudíveis ao náufrago, mas deixando-o menos solitário do que ele mesmo supunha. Por isso, sem ele saber, a linguagem salvou-o da loucura e preservou sua humanidade.

A busca desesperada por interlocutores (que apareceu na forma de ilusão) só reforça a constatação da necessidade humana de interação verbal. Nesse sentido, ao falar sobre a obra de Defoe como obra mítica que vivifica a solidão, Roland Barthes diz que Robinson Crusoé, transformando objetos e natureza em sujeitos humanos, enfrenta um problema de adaptação análogo ao que se apresenta na condição do "Viver Junto". A esse respeito, retomo o que o semiólogo diz, em forma de um pequeno fichamento, característico de uma escrita barthesiana (BARTHES, 2003, p.51):

Substituto da linguagem: o papagaio. Robinson Crusoé captura um papagaio para 'ensiná-lo a conversar comigo'. Muitos anos de adestramento - o papagaio chama Robinson Crusoé por seu nome. = Suscitar um Tu? Suscitar alguém que nos diga $T u$. Podemos fetichizar um objeto como pessoa, deus, termo de interpelação: o papagaio de Um coração simples ${ }^{2}$. Mas é

\footnotetext{
${ }^{2}$ Un coeur simple, novela de Flaubert na qual a empregada Felicite manda empalhar seu papagaio Lulu e acaba por confundi-lo com o Espírito Santo.
} 
impossível fazer com que um objeto nos diga $T u$. Daí o caráter insubstituível do papagaio de Robinson Crusoé: recebendo seu nome, ele se mantém como pessoa humana.

Caso diferente ocorre nas situações em que Robinson dialoga com Deus, ora referindo-se a seu nome, ora invocando-O, agradecendo-O etc.

Podemos indagar que papel assume Deus na vida de Robinson. Ele era seu interlocutor? E poderia sê-lo, na condição de ser Deus?

$\mathrm{Na}$ vida anterior aos desastres que se abatem sobre Robinson, Deus não tem um grande peso para o jovem, na sua própria ótica de quem revê a vida. As palavras que dirige a Ele são invocações destituídas de significados profundos - “Oh, meu Deus!” (p.50) -, em momentos de tempestades - “Deus! Como foi possível eu chegar a terra?” (p.52) -, ao se perceber em terra firme, logo após o naufrágio. Robinson afirma: "Eu não tinha, infelizmente, nenhum conhecimento do divino" (p.91), “agia como um mero inconsciente, segundo os princípios da natureza e pelo imperativo do senso comum” (p.91, grifos nossos).

Deus aparece-lhe, assim, como realidade, no momento em que descobre espigas de cevada de qualidade europeia, florescendo na ilha - portanto em clima inapropriado para seu cultivo. A emoção toma conta dele. Podemos acompanhar seu relato a esse respeito (p.81):

[...] Até à data eu agia sem usar bases religiosas [...] após ter visto cevada a crescer aqui, [...] comecei a pensar que Deus tinha miraculosamente sido a causa de este cereal crescer sem ter sido semeado [...] Este fato [...] fez-me vir lágrimas aos olhos, e comecei a felicitar-me por tal prodígio da natureza ter sido feito em meu benefício.

O sentimento de Robinson em relação a Deus arrefeceu, porém, quando ele lembrou-se de ter sacudido um saco que, provavelmente, teria sementes em seu interior.

A consciência de Robinson para a força do poder de Deus começa a despertar no momento de seu ataque de malária, formulando enunciados, junto com outra expressão - a das lágrimas: “[...] e, nesta confusão de alma, não sabia o que a minha boca dizia; mas eram principalmente exclamações do gênero: 'Deus!, quão miserável sou! Se ficar doente, morrerei, por certo, por falta de auxílio, e o que será de mim!" ”. Nesse momento, os enunciados ditos por seu pai retornam à mente, e Robinson responde a eles: “ 'Agora', disse em voz alta, 'as palavras do meu querido pai pertencem ao passado: a justiça de Deus alcançou-me $\boldsymbol{e}^{\prime}$ (p.93, grifos nossos).

A recorrência das respostas dadas por Robinson aos enunciados paternos, distanciados no tempo, mas presentes nas representações sígnicas interiorizadas pelo rapaz, demonstra que os conselhos do pai ainda repercutiam dentro dele na formulação de sentidos 
sempre renovados, em diferentes contextos de enunciação (ora nas tempestades no mar, ora em momentos na ilha).

$\mathrm{Na}$ condição de doença, Deus é invocado: "Então gritei: 'Deus, ajuda-me, porque estou em grande aflição!' "' (p.94, grifo nosso).

Deus não é um interlocutor presente. Mas, diferentemente dos "pretensos interlocutores", presentes em concretude e que Robinson pretendia humanizar, é um interlocutor real. E sua realidade consubstancia-se nas palavras da Bíblia - Bíblia que Robinson resgata do navio naufragado e que se torna o alicerce de suas interações verbais na ilha, dado que, após a "descoberta" de Deus, Robinson passa a dialogar com Suas palavras, diariamente.

É a voz de Deus que interage com Robinson?

$\mathrm{Na}$ verdade, é Robinson quem faz vibrar os enunciados atribuídos a Deus pelos seus atos de leitura. A voz de Deus se fez ouvir pela leitura. Ampliando o contexto das enunciações bíblicas trazidas no relato de Robinson, encontramos, no Livro dos Salmos, várias referências à voz de Deus e à Sua escuta ao clamor dos fiéis:

\section{9}

3 Ouve-se a voz do Senhor sobre as águas;[...]

4 A voz do Senhor é poderosa; a voz do Senhor é cheia de majestade.

5 A voz do Senhor quebra os cedros; sim, o Senhor despedaça os cedros do Líbano.[...]

7 A voz do Senhor despede chamas de fogo.

8 A voz do Senhor faz tremer o deserto; [...]

9 A voz do Senhor faz dar cria às corças e desnuda os bosques; e no seu templo tudo diz: Glória! (p.566).

\section{1}

Ouve, ó Deus, a minha súplica; atende à minha oração.

\section{4}

Ouve, ó Deus, a minha voz nas minhas perplexidades.

\section{6}

19 Entretanto, Deus me tem ouvido e me tem atendido a voz do coração.

No Salmo 19, encontramos:

2 Um dia discursa a outro dia, e uma noite revela conhecimento a outra noite.

3 Não há linguagem, nem há palavras, e deles não se ouve nenhum som; 4 no entanto, por toda a terra se faz ouvir a sua voz, e as suas palavras, até aos confins do mundo (p.561).

Nos discursos silenciosos da criação seria possível ouvir as palavras de Deus. E a Bíblia, ao alcance do aflito, estava ali, ao seu alcance, bastava ler; mas como diz Robinson 
Crusoé, ler com "conhecimento da minha posição, e dum ponto de vista verdadeiramente bíblico de esperança” (p.99), o que significava, para ele, a esperança de ser ouvido por Deus. Como todo ser humano, Robinson também queria ser escutado...

Livro dos Livros, a Bíblia também constitui um ato de fala. São palavras de Bakhtin (1999, p.123):

O livro, isto é, o ato de fala impresso, constitui igualmente um elemento da comunicação verbal. Ele é objeto de discussões ativas sob a forma de diálogo e, além disso, é feito para ser apreendido de maneira ativa, para ser estudado a fundo, comentado e criticado no quadro do discurso interior [...]. Assim, o discurso escrito é de certa maneira parte integrante de uma discussão ideológica em grande escala: ele responde a alguma coisa, refuta, confirma, antecipa as respostas e objeções potenciais, procura apoio etc.

Livro e leitor em diálogo silencioso, fomento de discurso interior. A possibilidade da leitura solitária adveio com a difusão da leitura silenciosa, ainda na Idade Média, permitindo uma relação privada entre o leitor alfabetizado e o livro. No que se refere à leitura da Bíblia, essa forma de ler permitiu uma nova relação entre o homem e a divindade, alterando o exercício da espiritualidade. Robinson marca uma posição ideológica contestadora de um catolicismo que considerava a interpretação do Livro Sagrado como monopólio da Igreja. Expressa por Lutero na Reforma Protestante, a interpretação do texto sagrado abria-se a uma leitura individual, já que se buscava um sentido literal, ou seja, um sentido existente nas linhas do texto (e não nas entrelinhas como no começo da Idade Média), passível de ser encontrado por uma leitura cuidadosa. Essa premissa teve desdobramentos no calvinismo e no puritanismo. Diante desses fatores, a privatização da leitura estabeleceu-se como característica da Europa Moderna.

Ao lado das leituras, as interações verbais entre Robinson e Deus assumem formas de súplicas: “Deus, ajuda-me, porque estou em grande aflição!’ (p.94).

A situação de doença, febre, medo de morrer juntaram-se às recriminações da consciência de Robinson, conduzindo-o a orar, como mencionado acima, e a refletir " $O$ que era esta terra e mar de que já tinha visto tanto? De que modo foram feitos? E o que era eu e todos os outros seres, selvagens ou mansos, humanos ou animais? Como tínhamos aparecido?” (p.95). 
Indagações que se remetem a versículos bíblicos:

\section{Isaías 40}

26 Levantai ao alto os olhos e vede. Quem criou estas cousas? Aquele que faz sair seu exército de estrelas, todas bem contadas, as quais ele chama pelo nome; por ser ele grande em força e forte e poder, nem uma só vem a faltar.

Ao perguntar, Robinson dirigia-se a si mesmo: "O mundo interior e a reflexão de cada indivíduo têm um auditório social próprio bem estabelecido, em cuja atmosfera se constroem suas deduções interiores, suas motivações, apreciações etc.” (BAKHTIN, 1999, p.112-113).

Lendo a Bíblia, ele depara-se com as seguintes palavras: "Chama-me no momento de aflição, e salvar-te-ei, e então darás graças" (p.96).

E ele próprio confessa: “As palavras eram muito adequadas ao meu caso [...]" (p.96), ou ainda, “[...] as palavras causaram-me grande impressão, voltando a elas muitas vezes $[\ldots] ”($ p.97).

O nome de Deus invocado traria a salvação esperada. Essas palavras adequavamse ao contexto de enunciação que se formava com a evolução da doença, adquirindo grande sentido para o rapaz.

É interessante notar aqui as relações de sentido que envolvem a palavra "salvar" dentro do enunciado bíblico e no fluxo verbal que elabora e reelabora a compreensão de Robinson.

Salvar, no enunciado da Bíblia, encontra-se como elo entre o apelo a Deus e sua glorificação. Citamos o Salmo de Davi - Oração no meio de grande perigo:

142 Ao Senhor ergo a minha voz e clamo, com a minha voz suplico ao Senhor.

2 Derramo perante ele a minha queixa, à sua presença exponho minha tribulação.

7 Tira a minha alma do cárcere, para que eu dê graças ao teu nome.

Tendo rezado e obtido a recuperação da malária, Robinson sentiu-se salvo do perigo da morte, mas uma parte da enunciação divina ficara sem a resposta esperada (compreensão responsiva) - Robinson não dera graças. Ao perceber isto, o rapaz se pergunta como Deus o salvaria da prisão na ilha, se ele não LHE rendia glórias e nem se arrependia de suas ações anteriores. Esse enunciado constitui-se imbuído pelo sentimento que o jovem tinha de ser um cativo. Tal sentimento aparece expresso quando, ao rever sua vida antes das leituras da Bíblia, diz: 
Antes, quando andava, fosse na caça, ou visitar a terra, a angústia na minha alma, à vista da minha condição, podia soltar-se e tomar posse de mim, ao pensar nos bosques, nas montanhas, no deserto em que estava, e, prisioneiro, encerrado pelas eternas trancas e ferrolhos do mar, numa terra selvagem e desabitada, sem salvação (p.113-115).

Para o jovem, a ideia de salvação relacionava-se à libertação de aflições da vida concreta. Deus, aclamado, poderia livrá-lo da doença e libertá-lo da ilha. Outras palavras bíblicas, contudo, produziram novos sentidos para ele: "Ele é glorificado como Príncipe e Salvador, para dar o arrependimento e para dar o perdão" (p.98). A elas Robinson responde, aos gritos: “Jesus, filho de David, Jesus, glorificado Príncipe e Salvador, dá-me o arrependimento!” (p.99), como uma oração, passando a considerar um novo sentido para a palavra salvação: um sentido teológico de felicidade eterna obtida após a morte, pela libertação dos pecados. Ele diz em seu relato: "Comecei a entender as palavras num sentido diferente do que lhes tinha dado antes" (p.99).

Se, para Robinson, o texto era entendido "pelas linhas", interpretamos essa mudança como a indicação de que os sentidos estão integrados aos contextos imediatos da enunciação, constituindo, por isso, eventos únicos, irrepetíveis.

No momento de sua doença, Robinson tem imagens de morte e diz que tanto seu espírito fica perturbado quanto seu corpo exausto. Relata ter encontrado, em um caixote, a cura para o corpo - o tabaco com que se trata, tal como o faziam os brasileiros - e para a alma, a Bíblia. A palavra bíblica salvar-te-ei volta-lhe constantemente à mente.

Tal fato remete-nos à força do poder curativo.

Cura pelo tabaco. Introduzido pelos espanhóis na Europa cinquenta anos após o descobrimento da América, o tabaco, inicialmente, foi considerado uma planta com milagrosos poderes curativos e era conhecida como o "divino tabaco" e "santa erva nicotina" (BURNS, p.515).

Cura pela palavra. Além de lembrar da figura de Sheerazade, trazemos palavras de Roy Potter, extraídas do capítulo: "Expressando sua enfermidade: a linguagem da doença na Inglaterra georgiana" (POTTER, 1993, p.366):

A doença põe a linguagem sob tensão. Temos uma dor: buscamos em vão pela palavra certa que comunique a natureza e intensidade do que estamos sentindo, e que esclareça exatamente em que ponto sob nossa pele ela está localizada. Isso é algo difícil, porque nossa linguagem de dor não é nem objetiva nem bem diferenciada. Com freqüência temos de perseverar na identificação da dor como um sintoma de alguma entidade mais abrangente: um mau funcionamento, deficiência, distúrbio, doença - e de maneira bastante óbvia, os pontos críticos aos quais uma dessas categorias seria aplicada. Afinal de contas, ao dar rótulo ao problema espera-se diminuir a 
ansiedade da ignorância. A nomeação de doenças envolve classificação, promove o prognóstico e indica a terapia. Como diz o velho ditado, uma doença nomeada é uma doença quase curada.

A leitura da Bíblia entranhada no contexto imediato vivido por Robinson vai provocando respostas, elaborações de novas enunciações, dando-lhe sensações reconhecíveis por qualquer leitor que interage com o texto de sua leitura:

Mas agora comecei a ter novos pensamentos; diariamente, leio a palavra de Deus [...] uma manhã, estando muito triste, abri a Bíblia nestas palavras: Eu nunca, nunca te abandonarei, nem te esquecerei; imediatamente, vi que estas palavras eram para mim; para quem mais poderiam ser, dirigidas desta forma, mesmo no momento em que me lamentava da minha situação, como alguém esquecido por Deus e pelos homens? 'Bom', disse eu, 'se Deus não me esquece, que más consequências poderá ter, ou que interesse tem, que o mundo me esqueça, vendo, por outro lado, que, se tivesse todo o mundo e devesse perder o favor $e$ a bênção de Deus, não haveria comparação possivel na perda?' (p.114, grifos nossos).

As palavras de Deus são ouvidas pela leitura diária de Robinson: esta tornou-se um dever para ele e alimentou o fluxo da linguagem entre os dois interlocutores:

Eu nunca, nunca te abandonarei, nem te esquecerei (p.114).

[...]

Crê no Senhor e anima-te, Ele dar-te-á forças; crê, repito, no Senhor" (p.155).

[...] dou sinceramente graças a Deus por me ter aberto os olhos, mesmo através das desgraças [...] (p.114).

[...]

E assim ia vivendo confortavelmente, [...] Isto tornava a minha vida melhor do que a vida social, pois, quando sentia necessidades de conversar, perguntava-me se o dialogar com os meus próprios pensamentos e, como espero poder dizer, mesmo com Deus, através de jaculatórias, não seria melhor que o maior divertimento da sociedade humana (p.135).

[...]

Quando cheguei, caí de joelhos e dei graças a Deus por me ter salvo (p.140).

Robinson dialogava com Deus pela leitura e pela oração. E, novamente, com a nossa leitura iluminada por estudos do Círculo de Bakhtin, detectamos, em seu relato, a importância dos contextos imediatos da enunciação para a construção dos enunciados.

Assim é que, um dia, encontrando uma pegada na areia, vê seu mundo desmoronar, jogando-o na incerteza da presença de canibais na ilha e afetando seus contextos de oração. Embora seu relato não apresente os enunciados ditos em oração nas diferentes circunstâncias, pode-se depreender a ocorrência desse fato pelo testemunho de Robinson, 
especialmente ao estabelecer relação entre o "estado de espírito" e o cérebro, ou seja, a atividade mental, o discurso interior. Robinson diz (p.160):

[...] eu rezava a Deus como se debaixo de grande pressão ou sofrimento, cercado de perigo e na expectativa, todas as noites, de ser morto e devorado antes que amanhecesse. E tenho de testemunhar, pela minha experiência, que uma situação de paz, agradecimento, amor e afeição é moldura mais própria para a oração que o terror e a aflição. E que, sob o temor dos acontecimentos desconhecidos, o homem não está preparado para a confortante realização do dever de rezar a Deus, como está para o arrependimento no leito de doença, porque este estado de espírito afecta o cérebro e as outras partes do corpo, e as doenças do espírito são muito mais incómodas do que as do corpo, e muito mais ainda porque a oração é um acto do espírito e não do corpo.

Orar é rezar, recitar, ler em voz alta e clara um discurso ${ }^{3}$. Sendo a oração um discurso, constitui-se de signos verbais, interiorizados na consciência; ao relembrarmos a condição da palavra como material flexível, sem maiores exigências para ser produzida, podemos entender o que Robinson diz, à luz de conhecimentos da filosofia da linguagem: a oração como ato do espírito é expressão de signos interiores, de uma vida psíquica, enraizada num contexto (enfatizamos a ideia do contexto muito maior do que moldura). $\mathrm{O}$ enunciado de Robinson, acima transcrito, permite-nos afirmar que as preces são determinadas pelas pressões sociais a que está submetido o locutor.

Mas Robinson, sozinho, estava submetido a pressões? Obviamente, até encontrar saídas para suas demandas de sobrevivência, havia a pressão de atender a necessidades básicas. Mas para desenvolver seus trabalhos havia tempo suficiente. Ele relata que sofria a tormenta de uma pressão dos pensamentos; para ela, encontrou uma saída - a escrita de um diário. Consta de seu relato (p.69):

Comecei então a pensar seriamente na minha situação e na situação a que estava reduzido e decidi pôr tudo por escrito, não tanto para deixar para alguém que viesse depois de mim, pois desconfiava de vir a ter sucessores, mas principalmente para me livrar dos meus pensamentos e da contínua meditação sobre eles, o que me atormentava o espírito.

A escrita do diário não foi o primeiro ato de impressão de palavras feito por Robinson Crusoé no que ele chamou, posteriormente, de seus domínios. Após os primeiros dias de permanência na ilha, ele gravou com uma faca, em um poste, os seguintes dizeres, em letras maiúsculas: “Desembarquei aqui em 30 de Setembro de 1659” (p.68). Fazendo uma cruz, cravou-a no local onde tinha desembarcado. Seu intuito era não perder a noção de

\footnotetext{
${ }^{3}$ Oração: origem etimológica - vem do latim oratio-onis, de onde se originam as palavras orador, oral, oratório.
} 
tempo, devido à "falta de livros, penas e tintas", e poder preservar os dias de descanso. O poste tornou-se o calendário de Robinson e o sétimo dia apresentava um entalhe maior do que os outros, bem como o primeiro dia de cada mês.

Poderia essa inscrição isolada ser considerada um enunciado?

Segundo Bakhtin, mesmo "uma inscrição num monumento é uma resposta a alguma coisa e é construída como tal. Não passa de um elo da cadeia dos atos de fala" (1999, p.98). Diante dessa afirmação, dentro de qual cadeia de atos de fala poderíamos inserir a inscrição de Robinson numa vasta rede de possibilidades?

Os atos de posse de novas terras, marcados pela cruz e pela palavra escrita, realizados por potências em condições de aventurarem-se pelos mares desconhecidos, visto que a empreitada era possível a locais que já tinham consolidado a formação de sua monarquia nacional; a ação do sujeito em afirmação - [EU] Desembarquei - ação do homem no mundo que abria espaços aos não nobres de nascimento; cristianismo e cultura letrada gravadas sobre a madeira, disseminando-se em locais insólitos; domínio da cultura sobre a natureza; colonialismo em terras selvagens, a explorar riquezas em benefício de metrópoles; divisão do tempo de acordo com um calendário cristão, com profundo respeito ao dia de descanso; são atos de fala que se inserem na comunicação verbal da qual a inscrição de Robinson é um prolongamento.

Uma escrita continuada revelou-se forma de organizar o tempo, pela elaboração de um diário que teve a duração de um ano, enquanto havia estoque de tinta, ao mesmo tempo em que aliviava a pressão interna sentida pelo náufrago. Embora Robinson não o soubesse, a escrita do diário representava, também, uma forma de privatização, na medida em que, como afirma, não fora feita com interesse de divulgação.

Robinson inicia a escrita do seu diário após organizar o espaço em que vivia e ter confeccionado uma mesa e uma cadeira que lhe permitiriam ter mais conforto para escrever. É interessante notar que somente após ter arrumado seus pertences é que se sente em condições de escrever, pois diz: "Foi então que comecei a manter um diário, pois até aí tinha estado tão ocupado, e não só com o trabalho, mas também com um estado de espírito deplorável que o diário ficaria cheio de coisas néscias" (p.73). E exemplifica como teria ficado sua escrita nessas condições. Comparando as formas de escrita - a que considera cheia de coisas néscias e a que apresenta como o diário propriamente dito -, vemos que ele formaliza a linguagem utilizada, suprimindo situações vividas (como ter vomitado a água do mar que engolira, ter batido em si mesmo, chorado, sentido medo, ter dado asas à imaginação, como um louco). Ao invés de registrar suas atitudes de loucura, opta por organizar a linguagem para falar da sua 
experiência, objetivando-a. Por outro lado, as duas formas de elaboração de escrita aparecem no relato autobiográfico, como o avesso e o direito de uma mesma moeda. Essa aparente "supressão" de uma linguagem que explicita certos atos corporais leva-nos a pensar nas novas atitudes em relação aos corpos que se estabeleceram entre os séculos XVI e XVIII, instalando um pudor novo, uma "literatura de civilidade," sem gestos excessivos (REVEL, 1991).

O modelo de civilidade foi caro aos protestantes e calvinistas. Revel $^{4}$ afirma:

As civilidades visam a criar entre os homens as condições de um relacionamento agradável, lícito, e cada vez mais conforme às reforçadas exigências da religião. Assim, elas impõem a seus leitores comportamentos que satisfaçam às normas de uma sociabilidade cada vez mais imperativa e insinuante. Levando ao extremo a lógica de Erasmo ${ }^{5}$, elas no limite situam todo ato individual sob o olhar de todos. Ao mesmo tempo, contudo, convidam cada indivíduo a separar em si mesmo o que é mostrável (civil e, portanto, bom) do que todos - ele também - devem ignorar.

Robinson registra o início de seu diário em 30 de setembro de 1659. Apresenta-se formalmente e nomeia o local como "Ilha do Desespero". Antevia a morte, por fome, ataque de feras ou de selvagens. Nesta situação podemos compreender a denominação que escolhe para o local - não era a ilha civilizada na qual nascera, não era a ilha fornecedora de lucros; era a ilha do isolamento humano, na qual poderiam existir selvagens que não eram humanos, não eram civilizados e nem cristãos. Como já foi dito, Robinson vem a revelar que os teme mais do que ao próprio Diabo.

Em seu diário, o rapaz mostra ter organizado um horário de trabalho, com tempo para caçar, dormir, gozar recreação, além de ter planejado a divisão dos espaços de sua moradia para comportar adequadamente armazém, cozinha, sala de jantar e adega, numa nova maneira de conceber os espaços em razão de sua funcionalidade.

Predomina, assim, o registro das atividades realizadas, apresentando um caráter bastante descritivo. É somente a partir de 18 de junho, quando surgem os primeiros sintomas da malária, que os relatos adquirem mais expressividade e reflexão. Na pior fase da doença, tem um sonho que é também relatado. Ao fim de um ano, por acabar a tinta, encerra a escrita, dizendo que o 30 de setembro foi guardado para a religião, com confissão de pecados, reza e jejum. Quando o material para escrita escasseia, Robinson diz que só escreverá os fatos mais importantes de sua vida, sem fazer o memorando diário, mas estes não ficam explicitados.

Ao constatar o caráter descritivo e objetivo do diário de Robinson, somos levados a indagar qual o sentido da descrição minuciosa das atividades e condições meteorológicas da

\footnotetext{
${ }^{4}$ Ibidem, p. 185 .

${ }^{5}$ Referência ao autor de “A civilidade pueril”, publicado pela primeira vez na Basileia em 1530.
} 
ilha, dada a pouca quantidade de tinta para escrever. Registrar fatos, sem comentá-los, poderia ser uma forma de o náufrago representar o mundo?

Tentar compreender esse aspecto nos conduz ao pensamento e uso da linguagem na Europa Moderna. Vivendo os tempos do Iluminismo, o pensamento europeu advogava a crença no uso da razão e na importância das sensações como fontes de conhecimento, diferentemente de orientações teológicas do passado. Robinson explicita (p.72):

[...] e aqui devo notar que, se a razão é a substância e a origem da matemática, também, expondo e observando tudo com a razão e fazendo das coisas os julgamentos mais racionais, todo homem pode, com o tempo, dominar qualquer profissão.

A nova epistemologia implicava no "testemunho dos sentidos", o que validava as descrições, tal como se descreviam as observações da nascente ciência moderna. Uma nova forma de escrever também aparecia: "Locke também associava a forma correta de usar a linguagem com o método apropriado de investigar a natureza, afirmando que as palavras só são úteis se estiverem baseadas na atenção às 'aparências óbvias' e às 'qualidades sensíveis' " (AARSLEFF, 1982, p.57 apud OLSON, 1997, p.190). Lembrando Foucault (1970, p.209), o próprio Olson diz que, no século XVII, "para representar algo autenticamente, a linguagem devia ser aproximada o mais possível do olhar observador, 'e as coisas observadas deviam ser aproximadas tanto quanto possível das palavras' ".

Dentro dessa forma de pensamento, poderíamos entender as pinturas holandesas do século XVII, que primavam pela representação do visível. 


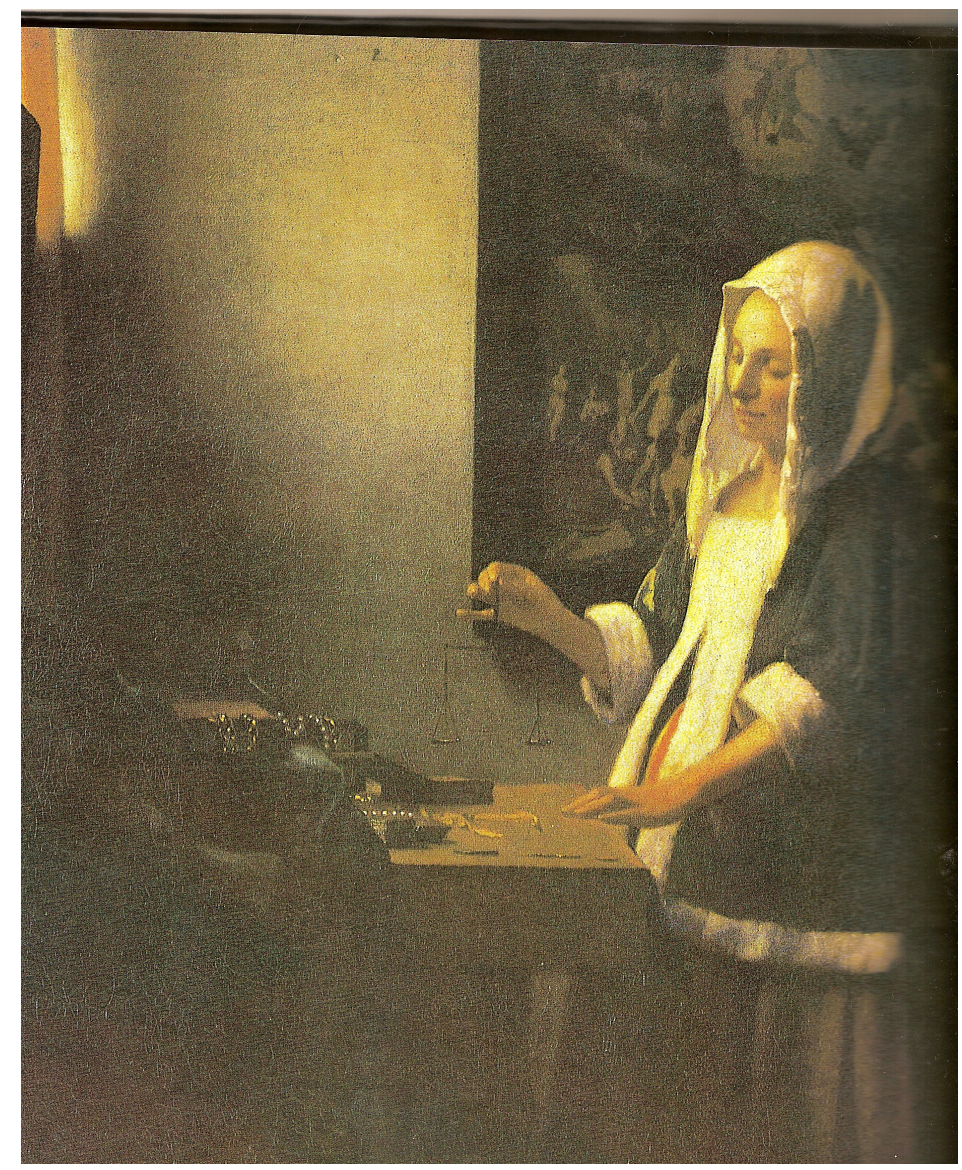

Figura 11: Quadro: Mulher Pesando Ouro (Jan Vermeer- 1632-75).

E assim podemos compreender o diário de Robinson, ou pelo menos grande parte dele, como um relato de fatos observáveis por qualquer outra pessoa que estivesse em sua posição, numa semelhança com o relato científico de uma experiência de laboratório, acessível a um observador:

17 de Dezembro. Deste dia até 20, coloquei prateleiras e enterrei pregos nos postes, para pendurar tudo que pudesse sê-lo, e então comecei a ter a casa arrumada.

[...]

25 de dezembro. Chuva o dia todo.

[...]

27 de dezembro. Matei uma cabra nova e acertei noutra, que agarrei e levei para casa presa com um cordel; quando cheguei, liguei e pus talas na pata que estava partida.

[...]

20 de junho. Sem descanso toda a noite, dores de cabeça violenta e estado febril.

Tendo buscado uma relação de sentido do diário de Robinson com enunciados do discurso científico da época e novas maneiras de ver o mundo, podemos indagar que outros sentidos poderiam ser apreendidos, à luz de conhecimentos atuais? 
Segundo David Olson (1997, p.213) "mesmo uma simples descrição dos fatos observados não é uma mera representação verídica, e sim uma asserção feita por um autor"; nela há representação de um ponto de vista e de um valor ideológico envolvido. Descrever é uma forma de pensar o mundo.

É importante lembrar que diários não são escritos para publicação, estando ligados ao âmbito privado. Robinson, ao escrevê-lo, vive a solidão do escritor, vive uma situação de paratopia. Mas diz encarar sua escrita como alívio de pressões interiores. Em um momento do seu relato diz: [...] aliviar-me pelas palavras [...]. Se o seu diário responde a enunciados de uma cadeia verbal, a quem ele se dirige dado que Robinson não nomeia possíveis leitores a seus escritos? Seria para si mesmo, para aliviar suas angústias? Dar sentido à sua vida? Salvar-se pela linguagem? Por que escreve?

A escrita de diários representou uma prática em crescimento na chamada era clássica (séculos XVI, XVII e XVIII) quando a visão do sujeito adquiriu importância e os processos de alfabetização e de leitura puderam ser difundidos. Segundo Ariès, em prefácio à "História da Vida Privada 3" (1991), um dos indícios de privatização da vida foi a escrita de diários íntimos que, na maioria das vezes, se justificava em si. Escrever por prazer, sendo o interlocutor de si mesmo. Mas o diário de Robinson, nascendo no âmbito do privado, sustenta uma visão de sujeito ao ser publicado no âmbito público, não tendo o destino de muitas dessas escritas que era a destruição.

Embora fosse uma prática a escrita de diários, recordemos que Robinson diz valer-se dela com o fim específico de usar as palavras como fontes de alívio. Poderia ser a escrita de palavras uma forma de remédio da alma?

Quem tem a escrita como companheira, quem luta com palavras, pode nos fazer refletir a respeito:

AUGUSTO DOS ANJOS

A princípio escrevia simplesmente para entreter o espírito... Escrevia mais por impulso de idiossincrasia do que por uma propulsão consciente. Entendi, depois disso, que devia, como Vulcano, sobre a forja ardente da ilha de Lemnos, trabalhar contente, durante as 24 horas do dia! Riam de mim, os monstros zombeteiros. Trabalharei assim dias inteiros, sem ter uma alma só que me idolatre... Tenha a sorte de Cícero proscrito ou morra embora, trágico e maldito, como Camões morrendo sobre um catre! ${ }^{6}$

\footnotetext{
${ }^{6}$ Fonte: GULLAR, Ferreira. Toda a poesia: Augusto dos Anjos. 3ed. São Paulo: Paz e Terra, 1995.
} 
MONTEIRO LOBATO

Escrever pode ser um ato puramente imitativo, ou uma exigência orgânica. Sempre escrevi por exigência orgânica, isto é, quando qualquer coisa, em meu organismo, exigia e impunha a fixação do pensamento em palavras para alívio interno. Nunca escrevi por sugestão externa. O livro mais interessante que poderia fazer seria a história de meus contos... ${ }^{7}$

CLARICE LISPECTOR

Escrevo como que para salvar a vida de alguém, provavelmente a minha. ${ }^{8}$

Com efeito, Robinson foi salvo pela palavra - no pensamento, na oralidade, na escrita.

Mas chegou o dia em que o rapaz ganhou um novo companheiro. Se, a princípio, a comunicação entre eles deu-se por meio de sinais, logo o senhor da ilha resolveu ensinar-lhe a língua, nomeando o selvagem como Sexta-Feira, dia em que havia salvado a sua vida. Fezse conhecer por "Patrão" (o uso da maiúscula é marca de expressividade) e ensinou-lhe o uso do "sim" e do "não" (termos opositivos).

Estabelecem-se aqui as relações de poder de que as palavras são portadoras e fundadoras, a ideologia constituinte e constituidora de uma camada burguesa industrial, a mentalidade dual que coloca em oposição a civilização e a selvageria.

Dado que o propósito deste trabalho é ressaltar a dialogia da linguagem na vida solitária de Robinson, não nos deteremos em analisar suas interações verbais com um Outro presente na ilha, embora haja interessantes possibilidades de estudo referentes às relações entre linguagem, cultura e poder, dada a assimetria estabelecida entre o náufrago e o recémnomeado/nascido Sexta-Feira.

Contudo, não poderíamos deixar de fazer considerações sobre o relato que Robinson faz dessas passagens de sua vida, pois essa sua escrita, após as experiências vividas, representa um reforço à nossa tese de que Robinson Crusoé é um paradigma do homem como ser de linguagem. Em seu relato, também buscaremos alguns indícios da marca do Outro nos enunciados, a presença da dialogia e o contexto extraverbal, atentando para a dualidade do pensamento, característica da Europa Moderna.

\footnotetext{
${ }^{7}$ Fonte: SILVEIRA PEIXOTO, José Benedito - Falam os escritores. 2ed. São Paulo: Secretaria da Cultura, Esportes e Turismo. 1971.

${ }^{8}$ Fonte: Leia, dezembro de 1987.
} 


\section{O RELATO AUTOBIOGRÁFICO: ENUNCIADOS, DIALOGIA, DUALIDADE NO PENSAMENTO}

As aventuras de Robinson Crusoé são a autobiografia de um ser de papel. Narradas em primeira pessoa, dão o tom de veracidade do relato, também enfatizado pela descrição factual e pela nota prévia do autor, distanciado na figura de editor. É o homem falando de sua história pessoal, diferentemente de quem escreve memórias, um gênero aristocrático em que se testemunham fatos históricos.

Momento de mudanças. A ficção renova-se no continuum de enunciados, portadora das mudanças ideológicas nos processos sociais.

O que nos narra Robinson, antes do seu desembarque na ilha?

Após contar sua genealogia, ele fala dos seus planos de viagens; nada ficamos sabendo sobre sua infância. Ao relatar a conversa com o pai, o faz de tal forma que o leitor consegue perceber os argumentos apresentados e contrários à sua partida (uso do discurso indireto), evidenciando a posição paterna. A referência ao discurso do Outro tem um tom analítico, sem conotação afetiva ou emocional:

[...] Disse-me que só homens em situação desesperada ou que aspirasssem a maior fortuna é que embarcavam à cata de aventuras [...].

[...] Disse-me para observar bem, e que verificasse sempre que as calamidades da vida eram sempre partilhadas entre a classe superior e a inferior [...].

[...] e, embora, ele não cessasse de rezar por mim, contudo atrevia-se a dizer que, se eu fizesse essa loucura, Deus não me protegeria $(\mathrm{p} .12,13,14)$.

Dessa forma, explicitada a presença do Outro no enunciado de Robinson, marcase, de forma clara, a dialogia da linguagem.

A não anuência do pai a seus projetos, aliada à sujeição da mãe aos discursos do marido, segurou o jovem Robinson em casa por mais um ano. Mas, um dia, um convite de um amigo para embarcar fez com que ele partisse, sem despedidas, nem avisos. A primeira tempestade vivida no mar o aterroriza. Ao ver o chamado dos homens para bombear a água do porão do navio, vai para sua cabine e senta-se na cama. Mais tarde, já em terra, lembrando da história do filho pródigo, diz: "Tivesse eu sido suficientemente sensato para ter voltado para Hull e para casa, seria feliz e o meu pai, a exemplo da parábola do nosso Salvador, teria mesmo morto a vitela mais gorda para mim” (p.22). 
Passada a primeira experiência, ele reencontra, dias depois, e em terra, o capitão do navio.

“' 'Jovem', disse ele, 'não deves ir para o mar nunca mais, deves tomar isto por um sinal forte e visível de que não és homem do mar.' 'Porquê, senhor', disse eu, 'não vai voltar ao mar?' 'Isso é um outro caso,' disse ele, 'é a minha profissão e, além disso, o meu dever; mas, como fizeste esta viagem como experiência, viste que amostra os Céus te deram do que te espera se persistes; talvez tudo isto nos tenha caído em cima por tua culpa, como Jonas no barco de Tarshish. Diz me', continuou ele, 'quem és tu e como vieste para o mar?" " (p.22).

As relações de sentido com o texto bíblico acham-se pontuadas na fala do capitão, mas fortificam-se ao lermos parte do capítulo 1 do Livro de Jonas:

1 Veio a palavra do Senhor a Jonas, filho de Amitai, dizendo:

2 Dispõe-te, vai à grande cidade de Nínive e clama contra ela, porque a sua malícia subiu até mim.

3 Jonas se dispôs, mas para fugir da presença do Senhor, para Társis; e tendo descido a Jope, achou um navio que ia para Társis; pagou, pois, a sua passagem e embarcou nele, para ir com eles para Társis, para longe da presença do Senhor.

4 Mas o Senhor lançou sobre o mar um forte vento, e fez-se no mar uma grande tempestade, e o navio estava a ponto de se despedaçar.

5 Então, os marinheiros, cheios de medo, clamavam cada um ao seu deus e lançavam ao mar a carga que estava no navio, para o aliviarem do peso dela. Jonas, porém, havia descido ao porão e se deitado; e dormia profundamente.

6 Chegou-se a ele o mestre do navio e lhe disse: Que se passa contigo? Agarrado no sono? Levanta-te, invoca o teu deus; talvez, assim, esse deus se lembre de nós para que não pereçamos.

7 E diziam uns aos outros: Vinde e lancemos sortes, para que saibamos por causa de quem sobreveio este mal. E lançaram sortes, e a sorte caiu sobre Jonas.

8 Então, lhe disseram: Declara-nos, agora, por causa de quem nos sobreveio este mal. Que ocupação é a tua? Donde vens? Qual a tua terra? E de que povo és tu?

9 Ele lhes respondeu: Sou hebreu e temo ao Senhor, o Deus do céu, que fez o mar e a Terra.

10 Então, os homens ficaram possuídos de grande temor e lhe disseram: Que é isto que fizeste! Pois sabiam os homens que ele fugia da presença do Senhor, porque lho havia declarado (p.886). 
Retomando o diálogo entre Robinson e o capitão, anteriormente descritos, fica patente a alternância dos falantes pelo uso de aspas. É uma forma clara de marcar a existência e os limites dos enunciados.

Não desistindo de atender aos apelos de uma vida no mar, Robinson torna-se um negociante da Guiné. Em uma de suas viagens, seu barco é atacado por piratas turcos e os sobreviventes são aprisionados.

Robinson assume, assim, a condição de escravo do capitão dos piratas (recordemos aqui uma característica da menipeia que é jogar com passagens bruscas, como, por exemplo, ascensões e decadências). A ideia de fuga passa a ser constante, mas só pôde ocorrer após dois anos, devido a uma circunstância habilmente aproveitada pelo jovem. Em suas andanças, chega ao Brasil, onde permanece por 4 anos, cultivando tabaco em seu engenho. Nesse momento, o jovem sente um isolamento linguístico, pois só tinha um vizinho com quem podia conversar, português de Lisboa e filho de pais ingleses.

O rapaz aprende a língua falada no Brasil; mas parte, com o fito de fazer comércio negreiro.

É interessante notar a descrição minuciosa que Robinson faz das localizações do seu barco no mar, e inseri-las numa cadeia de discursos sobre a representação do mundo em mapas medievais e portulanos.

Os mapas do mundo medievais, mappae mundi, de modo geral constavam de uma esfera cercada por outras esferas, representando os céus, ou discos cuja circunferência estava cercada de seres míticos. Skelton, que foi outrora curador dos mapas do Museu Britânico, comentou que os mapas do mundo medievais, guardados em sua maioria nos gabinetes de escrita (scriptoria), refletiam os arquétipos convencionais da visão cristã do mundo (OLSON, 1997, p.220).

No mesmo dia em que embarquei fizemo-nos à vela, rumando ao norte e seguindo a nossa costa, com a intenção de rumar para a costa africana, quando chegássemos a 10 ou 12 graus de latitude norte, o que suponho fosse habitual naquelas viagens daquele tempo. Tivemos muito bom tempo, só que demasiado quente, durante a viagem junto à costa, até chegarmos ao cabo de Santo Agostinho, onde rumando ao mar, perdemos a terra de vista, e navegámos como se nos dirigíssemos para a ilha de Fernando de Noronha, mantendo o rumo NE por $N$ e deixando estas ilhas a leste; neste rumo atravessámos o equador, passados cerca de doze dias, e estávamos, segundo a nossa última observação, a 7 graus e 22 minutos norte, quando um violento tornado ou furacão nos caiu em cima e nos pôs quase fora de nós; [...] pelo décimo segundo dia o tempo acalmou um pouco, o comandante [...] concluiu que estávamos a cerca de 11 graus de latitude norte, mas estávamos a 22 graus de longitude oeste em relação ao cabo de Santo Agostinho (DEFOE, 1975, p.46-47). 
Desde o século XIII, quando a bússola foi introduzida na Europa, procedente possivelmente da China, os métodos de navegação haviam se baseado em portulanos, cartas que indicavam a distância e direção entre portos e destinos, primeiramente no Mediterrâneo e depois, no século XV, nas costas atlânticas da Europa. Essas cartas apresentavam um perfil cuidadoso do litoral e dos portos existentes (OLSON, 1997, p.225).

Se o contexto imediato da enunciação de Robinson é a sua viagem por mar, há um contexto extraverbal que se refere à representação cartográfica do mundo na época moderna. Já se conhecia a esfericidade da Terra, representada com as propriedades matemáticas da esfera $\left(360^{\circ}\right)$ e que permitia a definição das linhas de latitude e longitude; o grande problema que se apresentava era como inventar e padronizar um sistema de projeção da superfície redonda da esfera numa representação do plano, de forma que fosse possível adequar as localizações no mapa (mundo conceitual) com as posições no mundo (terreno dos sentidos). Se se perdia a terra de vista, como orientar-se?

Os portulanos, cartas de navegação, possibilitavam que, a partir de linhas das rosas dos ventos das bússolas, os navegadores buscassem as rotas, estimando direção e distância navegada. Assim, a estimativa da direção ("como se nos dirigíssemos para a ilha de Fernando de Noronha”), a orientação por marcos visíveis (“deixando estas ilhas a leste”), o cálculo dos dias navegados ("passados cerca de doze dias") expressos por Robinson fazem parte de um esforço para se orientar em um mundo que se alargava em ideias, ações e espaços geográficos, sendo, sob os olhos humanos, uma representação grafada no papel.

Observar a carta de navegação não impediu que Robinson e seus homens ficassem perdidos no mar após uma tempestade, sem noção de qual terra, por fim, chegaram a avistar continente ou ilha? Só que, dessa vez, apenas Robinson se salvou.

Sozinho pelos próximos vinte e cinco anos, um dia, ele interpõe-se no caminho entre selvagens, perseguidores e perseguido. Saudando o fugitivo e protegendo-o, obtém seu reconhecimento, o que lhe valerá fidelidade e lealdade irrestritas.

Preocupado com o canibalismo e a conduta do selvagem acolhido, Robinson resolve instruí-lo na fé cristã. E aí se depara com a dificuldade de explicar o dualismo das figuras de Deus e do Diabo.

A crença de Sexta-Feira indicava um velho Benamucki como primeiro ser que existiu e criador de todas as coisas. Toda a criação deveria dizer "O" a ele. A ele voltavam os mortos, inclusive as vítimas dos atos canibais.

Ao falar sobre Jesus Cristo e Deus, Robinson ensinava-lhe que as orações proferidas na terra eram ouvidas no céu, o que causava grande admiração a Sexta-Feira, pois 
Benamucki só era capaz de ouvir a quem chegasse ao alto das montanhas; somente os oowocabbe (velhos sacerdotes) iam lá rezar (dizer "O") e voltavam contando o que Benamucki dissera.

Às afirmações de Sexta-Feira sobre o poder dos oowocabbe, Robinson sentia aumentar o repúdio que já possuía pela igreja católica - “compreendi que todos os padres têm as suas astúcias [...] de forma a manter a veneração do povo pelo clero". Mas, se era-lhe fácil falar do Deus cristão, difícil foi dar explicações sobre o demônio, ainda mais quando Sexta-Feira lhe diz: "se Deus muito forte, muito mais poderoso que Diabo, porquê [sic] Deus não mata Diabo, fazendo ele não fazer maís mal?" (p.209).

O espanto de Sexta-Feira pode ser entendido pelo fato de que a dualidade Deus/Diabo não fazia parte do arcabouço mental da cultura a que pertencia.

O pensamento dual é traço cultural e mental da Europa moderna, embora já se fizesse presente no pensamento da Grécia Antiga. Ele aparece em combinações binárias invertidas como natureza e cultura, civilizado e selvagem, obediência e desobediência, mandante e mandado, Deus e Diabo, citados, aqui, apenas alguns exemplos.

No discurso religioso, o Diabo aparece como um dissimulador, que age à semelhança de Deus, mas em formas contrárias - lembremos que Defoe escreve (1702) "Sempre que Deus ergue uma casa de oração/ O demônio constrói uma capela no mesmo chão. Tem seus ritos, seus agentes e seguidores". É ele quem Robinson pensa ser responsável pela pegada na areia, devido aos seus disfarces e à profunda inversão de situação que provocou no jovem, deixando-o completamente fora de si. Sua imagem contrapõe-se à imagem de Deus, junto a quem Robinson procura a salvação, já que seu ato de desobediência ao pai vinculava-o a uma atitude demoníaca. Retidão e pecado, Deus e Diabo indicavam a dicotomia em valores e entidades religiosas. A alma individual também vivia um combate entre as forças do bem e do mal.

Num tempo de guerras religiosas, a disputa fazia-se presente também na linguagem. "Se um homem diz para alguém" lamentava o politique francês François de La Noue, “ 'Este homem é um protestante', aos poucos ele responderá, 'Então ele é um herege perverso' e diz a um outro, 'Este homem é um Papista', e ele também dirá: 'Então ele é desprezível' [...]”. Assim os escritores tendiam mais e mais a adotar posições extremas e defendê-las extravagantemente; eles estavam preocupados com os polos do debate religioso e moral (CLARK, p.97-98). 
Na literatura, a contrariedade também apareceu com a figura da antítese. Clark ${ }^{9}$ aponta que ela influenciou a organização de trabalhos com fins didáticos, contrapondo comportamentos virtuosos com exemplos de reforço negativo. E cita o "tesouro de regras familiares - Of domesticall duties - do puritano William Gouge, do qual ele escreveu [sic]: 'porque contrários colocados juntos revelam um ao outro em suas cores vivas, anexei a cada dever a falta contrária, e a aberração dela' " ${ }^{\prime 10}$.

O relato de Robinson aponta para vários pares de antíteses, além dos já citados: segurança e insegurança, solidão e vida social, espaço privado e espaço público, castigo e perdão, catolicismo e protestantismo. Mas esta condição fica marcante quando ele apresenta a lista que escreveu, computando os pontos positivos e negativos da situação de desgraças em que caíra.

\begin{tabular}{|l|l|}
\hline MAU & BOM \\
\hline $\begin{array}{l}\text { Tinha sido atirado para uma ilha } \\
\text { desolada e horrível, sem esperanças de } \\
\text { salvação. }\end{array}$ & $\begin{array}{l}\text { Mas estava vivo e não afogado, como os } \\
\text { meus companheiros de bordo. }\end{array}$ \\
\hline $\begin{array}{l}\text { Estava só e isolado do mundo, o que } \\
\text { bastava para ser infeliz. }\end{array}$ & $\begin{array}{l}\text { Mas também estava separado do resto da } \\
\text { tripulação por ter sido poupado à morte, } \\
\text { e O que me salvou miraculosamente da } \\
\text { morte podia livrar-me desta situação. }\end{array}$ \\
\hline $\begin{array}{l}\text { Estava isolado da humanidade, era um } \\
\text { solitário, era um banido da sociedade. }\end{array}$ & $\begin{array}{l}\text { Mas não morria à fome, nem definhava } \\
\text { num lugar árido, sem possibilidade de me } \\
\text { manter. }\end{array}$ \\
\hline Não tinha roupas para me cobrir. & $\begin{array}{l}\text { Mas estava num clima quente, onde, se } \\
\text { tivesse roupas, mal as poderia suportar. }\end{array}$ \\
\hline $\begin{array}{l}\text { Não tinha meios de defesa ou de } \\
\text { resistência a qualquer violência, fosse de } \\
\text { homem ou de fera. }\end{array}$ & $\begin{array}{l}\text { Mas tinha sido atirado para uma ilha } \\
\text { onde não via feras que me atacassem, } \\
\text { como vira nas costas da África; que me } \\
\text { teria acontecido se fosse lá que tivesse } \\
\text { naufragado? }\end{array}$ \\
\hline $\begin{array}{l}\text { Não tinha com quem falar ou quem me } \\
\text { confortasse. }\end{array}$ & $\begin{array}{l}\text { Mas Deus tinha maravilhosamente } \\
\text { enviado o barco suficientemente perto da } \\
\text { costa, o que me permitiu que tirasse } \\
\text { tantas coisas inúteis, não só para as } \\
\text { minhas necessidades, como me permitiam } \\
\text { fornecer-me para o tempo que vivesse. }\end{array}$ \\
\hline
\end{tabular}

Quadro 2: Pontos positivos e negativos apontados por Robinson.

\footnotetext{
${ }^{9}$ Ibidem

${ }^{10}$ Ibidem, p.95.
} 
O próprio Robinson considerava as colunas como de "Deve" e "Haver", numa elaboração de lista contábil.

A respeito do pensamento dual na Europa moderna, Stuart Clark faz interessantes estudos em seu livro "Pensando com Demônios: a idéia de Bruxaria no princípio da Europa Moderna”. Ele afirma que a oposição não é um conceito simples e que existe um intercâmbio entre termos aparentemente muito diferentes, com presença de valorações positivas e negativas em classificações duais. No campo religioso, relata que havia autores que dividiam páginas em colunas com atributos cristãos e anticristãos. Cita a obra "Passional Christi und Antichristi" com gravuras de um pintor amigo de Lutero, em que cenas da vida de Cristo (página da esquerda) eram impressas de frente para cenas opostas da carreira do Anticristo papal (página da direita), geralmente com estrofes em verso sob cada ilustração.

Assim, entre Deus e o Diabo, entre o pecado e a expiação, entre a terra e o céu, entre a natureza e a cultura, entre palavras e silêncios, e todas as inter-relações que podem ser estabelecidas entre eles, Robinson permanece na terra do Desespero por 28 anos, dois meses e 19 dias. Um dia, após muitos pensamentos, planos e olhares para o horizonte sem fim, aconteceu sua partida. Ela pôde ser viabilizada com a chegada de um navio em que ocorrera um motim. Robinson restabelece a antiga ordem no navio e consegue partir com Sexta-Feira e a tripulação para a Europa. Deixa na ilha elementos amotinados que, caso retornassem, seriam enforcados na Inglaterra.

O que Robinson nos conta após sua saída da ilha?

Em nova referência bíblica, ele assevera "Poderia agora dizer que a parte final da vida de Jó era melhor do que o princípio” (p.268).

Ele aporta na Inglaterra em 11 de junho de 1687, mas tendo sido dado como morto após tão longa ausência e sem grandes negócios, sem pai e mãe, resolve ir para Lisboa para obter informações sobre sua plantação nos Brasis (seria essa denominação por causa da divisão da colônia em capitanias gerais?)

As notícias informaram-no de sua riqueza. À alegria junta-se a preocupação:

[...] pesava agora sobre mim uma responsabilidade e o meu problema era manter os meus bens em segurança. Não tinha caverna para esconder o meu dinheiro ou local onde pudesse ficar sem fechadura ou chave, até se tornar bolorento ou mareado antes que alguém lhe tocasse. Pelo contrário, não sabia onde o pôr ou a quem o confiar (p.270).

Ele manifesta intenção de se estabelecer nos Brasis, mas dois problemas se colocam para esta realização: era uma terra católica, e Robinson, mesmo sendo cristão, 
respondia dialogicamente em oposição à autoridade papal e aos tribunais da Inquisição, temendo tanto uma represália quanto abominando filiar-se a uma fé papista (conduta que já adotara em sua estada anterior na colônia).

Após encaminhar questões de negócios, Crusoé decide retornar para a Inglaterra, optando por um itinerário terrestre em sua maior parte. Um grupo de três ingleses, dois jovens portugueses, cinco criados e Sexta-Feira forma um pequeno pelotão do qual Robinson é nomeado "capitão".

Durante essa viagem, Sexta-Feira assume um papel importante, ao salvar da morte o guia do grupo, quando do ataque de lobos, e na luta corporal contra um enorme urso. Ao ver o imenso animal, Sexta-Feira fica satisfeito:

"Oh! Oh! Oh!" disse Sexta-Feira três vezes, apontando para ele; "Oh, patrão! Você deíxar mím ir! Mím apertar mão com ele; mím fazer você grande rír."

Estava admirado de o ver tão satisfeito. "És maluco", disse eu, "ele comete." "Come-me!" disse Sexta-Feira mais duas vezes "mím comê-lo: mím fazer você grande rír; ficar todos aqui, mim mostrar bom riso;" e sentou-se, tirou as botas e pôs uns escarpins como chamava aos sapatos rasos que trazia no bolso, entregou ao meu outro criado o cavalo e, levando a arma, correu, ligeiro como o vento (p.277, grifos nossos).

No discurso de Robinson, encontramos inserido o discurso de Sexta-Feira como uma unidade integral e integrante da construção. E é nessa relação que deve ser visto. Embora integrado, o discurso do Outro conserva sua característica. Note-se que não se trata da transcrição de um diálogo (como se apresentou no caso de Robinson em interação com o capitão do navio - p.114), mas da "recepção ativa do discurso de outrem" (BAKHTIN, 1999, p.146), no caso, o discurso de Robinson como contexto narrativo do discurso citado de SextaFeira. Esta presença do discurso do Outro é apresentada, no enunciado acima, por duas formas: as aspas, como marcas explícitas, e a tradução da palavra do Outro ("escarpins, como chamava aos sapatos rasos [...]”)

Sobre esta condição, Bakhtin alerta ${ }^{11}$ :

$\mathrm{O}$ erro fundamental dos pesquisadores que já se debruçaram sobre as formas de transmissão do discurso de outrem, é tê-lo sistematicamente divorciado do contexto narrativo. Daí o caráter estático das pesquisas nesse campo (o que se aplica igualmente a todas as investigações em sintaxe). No entanto, o objeto verdadeiro da pesquisa deve ser justamente a interação dinâmica dessas duas dimensões, o discurso a transmitir e aquele que serve para

\footnotetext{
${ }^{11}$ Ibidem, p. 148 .
} 
transmiti-lo. Na verdade, eles só têm uma existência real, só se formam e vivem através dessa inter-relação, e não de maneira isolada.

Retomando a questão da dialogia da linguagem, exemplificamos aqui as relações de sentido claramente demarcadas no discurso autobiográfico de Robinson. Citamos, novamente, nosso autor de referência: "O discurso citado e o contexto de transmissão são somente os termos de uma inter-relação dinâmica. Essa dinâmica, por sua vez, reflete a dinâmica da inter-relação social dos indivíduos na comunicação ideológica verbal [...]" (BAKHTIN, 1999, p.148). Realmente, pode-se verificar, no enunciado de Robinson, a assimetria social e a diferença cultural estabelecidas entre o europeu e o considerado selvagem. Robinson é o sujeito, o senhor da escrita.

O autor russo ainda coloca a importância que assume uma terceira pessoa - aquela para a qual estão sendo transmitidas as informações, pois ela reforça "a influência das forças sociais organizadas sobre o modo de apreensão do discurso" ${ }^{\prime 2}$. Com efeito, os leitores de Robinson, embora não aristocratas, eram participantes de uma cultura europeia.

Robinson oferece ao público o relato de suas "verdadeiras" aventuras. Para que seu auditório social o acompanhe e com ele compactue, ele se faz valer de controles de interpretação, de modo a atestar uma veracidade pelo fato de o dito tornar-se visível para o leitor. Assim, utiliza digressões, organiza pequenos resumos para maior facilidade de compreensão.

Ao compor sua autobiografia, Robinson insere uma cópia do seu diário, explicando que o já contado volta a aparecer sob essa forma. Por que, se há uma repetição de fatos, ele inclui o diário em seu relato?

Como técnica narrativa, a inclusão do diário aumenta o tom de veracidade do relato, pois se dá crédito a um indivíduo que testemunha sua experiência. Mas é importante lembrarmos que, estabelecendo laços com a sátira menipeia, o romance comporta a inclusão de gêneros intercalados: cartas, discursos oratórios, simpósios (BAKHTIN, 2005).

A inserção é feita de forma bem explícita - O DIÁRIO - mas, muitas vezes, apresenta limites imprecisos em relação à narrativa, e o narrador retoma - "mas voltemos ao meu diário".

Segundo Michel de Certeau, é com a escrita do diário que Robinson inicia sua conquista da ilha, de caráter capitalista, dominando o tempo e as coisas e produzindo aí seu querer. Recordemos que a escritura é, para o autor, a prática mítica moderna, da qual Robinson é figura exemplar.

\footnotetext{
${ }^{12}$ Ibidem, p. 146.
} 
Ao escrever, Robinson testemunha sua experiência, apresentando valores e condutas de vida aprendidas em suas inusitadas aventuras. Não é um sujeito que se propõe a buscas de autoconhecimento, mas é um Robinson que, com suas reflexões a partir do vivido, reflete e estabelece parâmetros que, talvez, poderiam constar da formulação de uma lista, tão a seu gosto.

Ele direciona caminhos para a relação com Deus e abre brechas para um relativismo cultural ao colocar em questionamento a criminalidade dos atos de canibalismo. Aponta a diferenciação de posições diante de uma realidade, ao entender que "aquilo que é a salvação para um homem é a destruição para os outros". Compreende que "nunca é tarde para aprender".

Sem entrar em julgamentos valorativos das reflexões de Robinson, vemos que, por meio da reflexão de sua experiência, ele pôde se constituir no sujeito de sua narração, articulando o já vivido em um relato.

O diário e o relato de Robinson representam dois tempos que se cruzam, duas escritas que se entrelaçam para contar a escritura do homem no espaço geográfico da ilha e no vazio de um papel. Caminhando à procura do seu lugar num mundo desabitado, Robinson cria espaços e histórias com pegadas e palavras, habitando a terra e o papel sobre o qual inscrevia seus enunciados.

Por isso, ao acompanharmos sua narrativa, caminhamos com ele, pela ilha, pelo tempo, pelo papel. A leitura das passagens de sua vida, de suas dúvidas, questionamentos, temores, alegrias e reflexões transforma-nos em Robinsons modernos, pois, como afirma Michel de Certeau, o leitor é um "Robinson de uma ilha a descobrir, [...] se desterritorializa, oscilando entre o que inventa e o que modifica" (1990, p.269).

A palavra, para Robinson, foi vida. Foi a praia onde se salvou. Como a praia, que não é a areia e nem o mar, mas sim o encontro dos dois, a palavra foi o encontro, consigo e com o Outro, onde Robinson repousou, alimentou-se, exorcizou-se de seus fantasmas, se afirmou e reafirmou-se como ser humano.

Crusoé foi personagem criado pela linguagem. Sua narrativa evidencia a força das palavras em sua vida. Seu criador, Daniel Defoe, continua vivo pelo poder e pela força da linguagem. Nós, seus leitores do século XXI, ainda somos alimentados por ela. 

Parte 4 



\section{A CONSTRUÇÃO DE CONSIDERAÇÕES FINAIS DESTE PERCURSO DISCURSIVO}

\section{- em busca de uma compreensão criadora: a difícil tarefa do pesquisador}

Compreender uma obra na perspectiva bakhtiniana é vê-la constituída e constituinte de um tempo histórico, de ideologias, respondendo ao mundo e interrogando-o ao mesmo tempo. Mais do que isso, porém, é buscar uma outra palavra que a ela se dirija, de forma que sentidos não revelados possam abrir-se, dadas as diferentes condições de tempo histórico e culturais do pesquisador que a interroga.

Ao tentar elaborar uma compreensão da obra de Defoe, busco, novamente, as perguntas que propulsionaram esta pesquisa. Que ampliações de sentido essa obra pode possibilitar, se iluminada por formulações teóricas posteriores? Que relações essa obra mantém com a ideologia do nosso cotidiano?

Do ponto de vista de sua inserção no início dos tempos modernos, ela nos coloca frente a um sujeito realizador, dono de seus atos, vitorioso perante as vicissitudes da vida. Um herói, mas não mais um herói mítico, e sim um herói de carne e osso com pele de papel. Um herói apartado do convívio humano, submisso e pecador, em busca do perdão e da salvação a serem dadas por um Deus criador. Um Deus detentor de uma Palavra/Verdade, inquestionável. As relações de Robinson com a Palavra do Senhor fizeram de Deus seu superdestinatário, ou seja, aquele de quem procede a Verdade. Embora a modernidade venha trazer a perda dessa Palavra identificadora, deixando o homem à mercê de si mesmo, Ela ainda se faz presente para Robinson Crusoé. Nosso herói é o homem racionalista, oriundo de uma Inglaterra onde havia liberdade no entender de Voltaire, beneficiado pela expansão da alfabetização, dos limites geográficos da Europa, de um século XVIII do Empirismo, das Luzes, em que o homem começava a assumir-se como sujeito de suas ações.

Como interrogar as surpreendentes e singulares aventuras de Robinson Crusoé, de modo a tentar responder nossas perguntas iniciais?

A partir do conceito da dialogia da linguagem na perspectiva bakhtiniana, fui conduzida a duas questões: Robinson estava tão solitário e perdido como supunha? O que sustentou a preservação de sua humanidade durante a total ausência do convívio humano? 
A reflexão nos conduz ao enraizamento das palavras em seus contextos históricos e extraverbais de enunciação. Estar perdido e solitário para Robinson era desconhecer o lugar em que se achava, o ponto geográfico de sua localização num mundo que ainda desvendava seus mistérios de mares e terras; era não saber as condições da ilha, se fértil ou não, habitada ou desabitada. Faltavam-lhe informações que lhe dessem referências. Sua solidão foi atribuída à ausência de convívio humano, pois solidão, etimologicamente falando, tem a raiz -só-, a mesma de solilóquio (monólogo). Nesse sentido, confirma-se a existência solitária de Robinson na ilha. Mas logo somos remetidos à presença do social em sua vida pela cultura interiorizada que ele trazia consigo e pelos materiais que recolhe do navio naufragado, corroborando posturas apresentadas no início deste trabalho. A nossa questão primordial, porém, ao perguntarmos sobre a real solidão de Robinson, liga-se a uma outra indagação: tendo a areia e a água da ilha, qual foi o elemento aglutinador (assim como um cimento) que deu condições de argamassa para sedimentar a falta física do Outro e a cultura, na construção de uma vida humana pós-naufrágio?

Respostas foram buscadas nos espaços de travessia, nos elos entre as palavras, nas pontes estabelecidas por elas e, ao encontrá-las nos atos verbais de Robinson, deparamos com o Outro da linguagem, consubstanciado nos discursos sociais interiorizados, na Bíblia como fala impressa, na escrita como necessidade interior (o Eu para mim). A dialogia da linguagem pulsava na ilha de um só habitante, tornando-o menos solitário do que ele mesmo supunha; pelo funcionamento da linguagem, pela memória enquanto recriação de experiências vividas, Robinson sobreviveu, viveu e achou seu lugar na ilha e no mundo civilizado, para o qual retornou.

A importância da linguagem em sua vida permite-nos, portanto, concluir que Robinson pode ser considerado um protótipo do homem como um ser de linguagem, pois esta evidenciou sua força dialógica durante os vinte e oito anos de afastamento da civilização, especialmente no período de total isolamento de convívio humano - um homem metalinguístico. Para além deste tempo, seu relato autobiográfico também pode ser considerado como sustentação da experiência vivida e dado de transmissão cultural dessa mesma experiência. As palavras de Robinson no primeiro capítulo do último livro da trilogia "Da solidão", em "Serious Reflections"- podem corroborar nossa tese, de uma forma que nem Robinson, nem Defoe poderiam suspeitar. Ian Watt fornece-nos material para tal afirmação. Ele diz (1997, p.156): 
"Da solidão" começa com uma nota pessoal: Crusoé confessa que 'às vezes' perguntava a si mesmo 'se poderia suportar' a vida solitária; e que a pergunta o levava à seguinte reflexão: 'parece-me que, no geral, a vida é, ou deveria ser, nada além de um ato universal de solidão (III, 2). No seu modo de ver, nada há de aflitivo na solidão, pelo menos 'enquanto o homem tiver a voz da alma para falar com Deus e consigo mesmo (III,3) (grifo nosso) ${ }^{1}$.

Robinson estava enraizado em sua cultura e dialogou com ela na ilha deserta. No que se refere aos modos de produção de artefatos e à solução de problemas imediatos, ele, certamente, inovou ao produzir o conhecido por meio de novas formas de produção; foi um inventor de novas possibilidades para criar o já conhecido. Esses modos de garantir a subsistência foram transmitidos aos amotinados que permaneceram na ilha, como orientações para conduzir a vida no local. Teve o mérito de registrar o testemunho da experiência vivida, pois, ainda que em descrição, este revela um modo de se acercar da realidade. Mesmo antes de escrevê-la, narrou-a a Sexta-Feira, ao comandante de um navio e aos homens que permaneceram na ilha.

Se Robinson tem sido visto como o paradigma do homem solitário e perdido numa ilha deserta (agora o encontramos menos solitário), em que essas condições se justapõem ao fato de o homem contemporâneo sentir-se perdido num mundo de informações com agilíssima possibilidade de obtê-las e solitário dentro da multidão?

O "perdido" da contemporaneidade, diferentemente de Crusoé, mostra um homem sem referências, com vazios de sentido em sua existência. Ser solitário não indica, necessariamente, falta da presença de Outro humano, mas parece a condição de, mesmo estando com o Outro, não se reconhecer e nem ser reconhecido.

Ao homem da contemporaneidade faz falta a existência de referências, a construção de sentidos. Que referências poderiam ser estas? Números de identificação é que não faltam. O tempo é preenchido com atividades ininterruptas; encontrar pessoas prescinde de presença física e ser reconhecido não é mais privilégio de pessoas com talento avalizado.

Dos inícios de uma privatização na Europa moderna, chegamos à exacerbação de uma sociedade individualizada. Mas Zygmunt Bauman (2001, p.60) nos diz: “O trabalho de que os homens estão encarregados hoje é muito semelhante ao que era desde o começo dos tempos modernos: a autoconstituir a vida individual e tecer e manter as redes de laços com outros indivíduos em processos de autoconstituição".

\footnotetext{
${ }^{1}$ As numerações que aparecem neste excerto referem-se à publicação de Robinson consultada por Watt. Edição Penguin, ligeiramente modernizada, organizada por Angus Ross (Harmondsworth, 1985).
} 
A dialogia entre a constituição das identidades e as relações de alteridade é condição para a construção de sentidos, tão vital à condição humana. E ela tem condições de florescer no âmbito da cultura, do espaço público.

E o que seria a construção de sentidos? Reportamo-nos a Bakhtin quando afirma que "aquilo que não responde a nenhuma pergunta não tem sentido para nós” (2003, p.381).

Para obter respostas, contudo, é preciso questionar. E a sociedade contemporânea não favorece a reflexão. Talvez a imensa quantidade de informações que parecemos instados a sempre ter conhecimento não propicie condições de tempo para serem, à semelhança de um processo metabólico, "digeridas" e assimiladas como alimento a um corpo/mente vivo de histórias. A esse respeito, Bauman, em seu texto "Books in the global dialogue of cultures" (UNESCO, 2000, p.23), recorda um "slogan” produzido por uma estação de rádio e televisão francesa, RTL, que dizia: “information, like coffee, is good when hot and strong”. A informação, servida como o café, é suficientemente forte para diluir o sabor da comida consumida momentos antes e quente para que possa suprimir sentimentos aflorados. Tal como a bebida, também esfria rapidamente.

A rapidez da veiculação das informações, o ativismo intenso do mundo em que vivemos compõe e compõe-se numa forma de "estar no mundo globalizado." Um mundo em que se pode estar, por via virtual e simultaneamente em vários lugares; pertencer a diferentes comunidades e viver, paralelamente, outras vidas. Essas condições têm implicações profundas no que se refere à elaboração de experiências e à escuta do Outro. Para o bem e para o mal.

Elaborar experiências não é acumular eventos na vida, estabelecer contatos variados e fortuitos, ter o tempo integralmente ocupado, ser constantemente solicitado. Elaborar experiências, no nosso entender, é buscar construir sentidos no diálogo com a vida, o que implica o estabelecimento de laços, conexões, pertencimentos, escolhas, desistências, em que pensamento e sentimento, passado e presente, ação e não ação, identidade e alteridade, palavra e silêncio interagem, construindo e reconstruindo, constantemente, o Homem. Para isso, o tempo não corre com Pégaso. Para isso é preciso não ser Narciso.

$\mathrm{Na}$ sociedade atual é ainda incipiente a escuta entre os vivos, e esvai-se a memória dos mortos.

A construção de sentidos precisa da comunicação com o Outro, da troca cultural tal como nos fala Gagnebin (2006). E a cultura não é feita de "instantâneos". No mundo globalizado contemporâneo, dadas as condições de existência, é um desafio manter elos com o passado. Retomamos Bauman (2001) para dizer que 
[...] em toda história humana, o trabalho da cultura consistiu em peneirar e sedimentar duras sementes de perpetuidade a partir de transitórias vidas humanas e de ações humanas fugazes, em invocar a duração a partir da transitoriedade, a continuidade a partir da descontinuidade, e em assim transcender os limites impostos pela mortalidade humana, utilizando homens e mulheres mortais a serviço da espécie humana imortal (p.146).

[...] E os homens e mulheres do presente se distinguem de seus pais vivendo num presente 'que quer esquecer o passado e não parece mais acreditar no futuro'. Mas a memória do passado e a confiança no futuro foram até aqui os dois pilares em que se apoiavam as pontes culturais e morais entre a transitoriedade e a durabilidade, a mortalidade humana e a imortalidade das realizações humanas, e também entre assumir a responsabilidade e viver o momento (p.149).

Se muitos querem esquecer o passado e não acreditam no futuro, há os que ainda insistem em atos de resistência: pela escrita, pelo discurso, pelo exercício de um magistério consciente e competente. E isto nos leva a considerações sobre linguagem e educação.

Se a linguagem é dialógica, a palavra deve ser atributo de todos. Para além de um caráter de senso comum que a afirmação pode induzir, ela nos incita a uma reflexão sobre o uso da palavra e sua possível manipulação ou banalização.

Fazer uso da palavra na perspectiva adotada neste trabalho é lançá-la como ponte a um Outro, ouvi-lo, entrando em interação com ele. É construir e ampliar sentidos em relação dinâmica com tempo e espaço presentes, em articulações que fogem a qualquer categorização que se queira delinear. É ato imprevisível, que não predefine o Outro nem sua resposta, mas que se acha aberto a escutá-lo e responder-lhe. Nesse sentido, é risco. Risco de dizer a própria palavra, risco de ouvir a palavra do Outro. Perigo de ousadia, liberdade, transgressão.

Escraviza-se um homem ao se escravizar sua palavra. Não foi pela formulação de uma nova língua, a Novilíngua, com redução drástica das palavras a serem usadas, que se procurou limitar os pensamentos das pessoas na utopia de George Orwell - 1984? Não é com a padronização de uso de palavras que se padronizam os sujeitos? "Com certeza", "normal", “é isso aî", "falou”, "fui”" são respostas padronizadas que vêm se incorporando ao vocabulário cotidiano, usadas nas mais diferentes situações de interação verbal.

Valorizar a palavra é valorizar o homem. Educar, numa perspectiva humanista, é acolher e enriquecer de sentidos a linguagem que constrói sujeitos da cultura. Da palavra que brinca à palavra literária, o que vale é o sabor que elas podem ter, intransferível e indizível por quem as experimenta.

A possibilidade de uso da palavra permitiu-nos a inserção em uma trama de tempos e discursos para interrogar a obra de Daniel Defoe. É provável que, para 
Robinson/Defoe, não existisse o Outro presente na palavra constitutivamente dialógica. O sentido literal atribuído à linguagem no século XVIII não implicava a leitura de entrelinhas. Foi o conhecimento da formulação teórica bakhtiniana que nos permitiu interrogar a obra dentro dessa perspectiva, buscando compreendê-la numa nova dimensão.

Com sons e silêncios de palavras, sozinho em uma ilha, Robinson evidenciou que nós, seres de carne e osso, somos seres de palavras em contínua interação com o Outro. Ao escrever sua história na ilha, Robinson foi encontrando seu lugar no espaço deserto e no mundo civilizado, que estava além de onde se encontrava. A dialogia da linguagem trazia o Outro da cultura, construído coletivamente. Assim, a identidade ia se forjando em dialogia com a alteridade de uma "não-presença".

A existência de sentidos que a linguagem lhe possibilitou durante a difícil vida de isolamento é, do nosso ponto de vista, uma nova vertente a ser somada a tudo que ele diz a nós, homens do século XXI. Homens que, na reflexão de Zygmunt Bauman, não vivem em ilhas circundadas por água como Robinson, mas estão, eles mesmos, imersos em "meios líquidos", tal a fluidez existente nas sociedades em que vivem.

Ao buscar o funcionamento real da linguagem, tendo em vista preocupações com o uso da palavra e da construção de sentidos nos dias de hoje, estivemos, especialmente, refletindo sobre as responsabilidades dos espaços educacionais na formação de gerações mais novas, notadamente nos universos de leitura e escrita. Leitura que começa antes da leitura convencional do código escrito:

"Poor old Robinson Crusoe [...] With a ring a ting tang [...]"

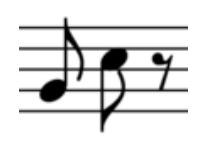

Desde o berço, há que se aprender a ler o "mundo da cultura, dos valores, dos costumes, das tradições, das comidas, das músicas, das danças, das histórias, das canções, dos rituais de celebração [...]" (DIAS, 2003, p.232).

Dedicada ao estudo da educação da pequena infância, a professora Dra. Marina Célia Moraes Dias alerta para a necessidade de se investir na escola, contra-atacando um mal de que a própria instituição é vítima: o consumo e a constituição de um saber descartável e utilitário. Para ela, há necessidade de se recuperar "o sentido da unidade da cultura e o fascínio pelo conhecimento mais elaborado"2.

\footnotetext{
${ }^{2}$ Ibidem, p.233.
} 
No mundo da virtualidade em que vivemos e do qual as crianças pequenas já são participantes, a circulação de palavras e experiências vividas, encarnadas, que construam sentidos, continua imprescindível. As experiências virtuais trazem aberturas para o conhecimento, mas não podem sustentar todas as necessidades de formação e sustentação do homem. Ao lado delas, o ser humano tem de continuar a produzir textos, como fala Bakhtin, sob pena de sacrificar sua humanidade, caso não o faça. E produzir textos e discursos não é juntar palavras, ter "slogans" pré-fabricados como respostas; é construir enunciados que estabeleçam laços com os Outros, interlocutores com discursos também construídos pessoalmente. O que se propõe é que haja circulação de discursos com sentidos, em que o passado possa continuar ecoando em renovações, para que a palavra seja valorizada e democratizada; para que a humanidade do homem não seja um simulacro, mas tenha vida verdadeira - fecundada e fecundante. 



\section{ROBINSON CRUSOE - WW}

CRUIKSHANK, GEORGE (1792-1878)



Figura 12: Robinson Crusoe - Washed Ashore After Shipwreck. 



\section{NOTÍCIA SOBRE UM NÁUFRAGO}

Quando o náu frago pisou em nossa isha

Thegou como alguém que alcançou seu destino.

Quase acredito que ao nos ver

đ̇ nós que havíamos corrido a ajudá-fo

Ele imediatamente sentiu compaixão.

Lá desde o início

Ocupou-se apenas de nossas coisas.

Tom a experiência do seu nau frágio

Ensinou-nos a velejar. Mesmo coragem

ESe nos instifou. Das águas tempestuosas

Falava com grande respeito, tafvez

Por terem vencido um homem como ele. Sem dúvida

Fiviam assim revelado muitos de seus truques.

Este conhecimento faria de nós, a funos de e

Fomens me/hores. Sentindo falta de certas comidas

Ele meShorou nossa cozinha.

Embora visivelmente insatisfeito consigo

Lamais se deixou ficar satisfeito com o estado de coisas

Em torno dese e de nós. Punca, porém

Durante todo o tempo em que passou conosco

Ouvimo-fo queixar-se de outro alguém que não ele mesmo.

MTorreu de uma velha ferida. Lá no seito

Experimentou um novo nó para nossas redes. \%̆tssim

Morreu aprendendo. 

Parte 5 



\section{BIBLIOGRAFIA}

AARSLEFF, H. From Locke to Saussure. In: OLSON, D. O mundo no papel: as implicações conceituais e cognitivas da leitura e da escrita. São Paulo: Ática, 1997.

ACOPIARA, M. de. (adapt.). As aventuras de Robinson Crusoé em cordel. São Paulo: Nova Alexandria, 2009. 48 p.

AGOSTINHO, S. Confissões. Tradução de J. Oliveira Santos e A. Ambrósio de Pina. Rio de Janeiro, Vozes. 2002.

APPLEBAUM, R. Robinson Crusoe Miths and Metamorphoses. Utopian Studies. Disponível em < http://findarticles.com/p/articles/mi_7051/is_n2_v8/ai_n28700454> Acesso em: 28 fev. 2009.

ARENDT, H. Entre o passado e o futuro. 5 ed. São Paulo: Perspectiva, 2001. 344 p.

ASSIS, C.P. (adapt. cordel). As aventuras de Robinson Crusoé. São Paulo: Editora Luzeiro Limitada, s.d.

AUTHIER-REVUZ, J. Entre a transparência e a opacidade: um estudo enunciativo do sentido. Porto Alegre, EDIPUCRS, 2004.

BAKHTIN,M. Marxismo e Filosofia da Linguagem. 9.ed. São Paulo: Hucitec, 1999. 196 p. Estética da criação verbal. 4.ed. São Paulo: Martins Fontes, 2003. 468 p.

A Cultura Popular na Idade Média e no Renascimento: o contexto de François Rabelais. 4.ed. São Paulo: Hucitec; Brasília: Editora da Universidade de Brasília, 1999. 419 p. 2005.

Problemas da Poética de Dostoiévski. 3.ed. Rio de Janeiro: Forense Universitária,

BARROS, D. L. P. de; FIORIN, José Luiz (orgs.). Dialogismo, Polifonia , Intertextualidade: Em torno de Bakhtin. 2ed. São Paulo: Universidade de São Paulo, 2003. $81 \mathrm{p}$.

BARROS, D. L. P. de. Contribuições de Bakhtin às Teorias do Discurso. In: BRAIT (org.) Bakhtin: dialogismo e construção do sentido. 2ed. rev. Campinas, SP: Editora da UNICAMP, 2005. 365 p.

BARTHES, R. Como viver junto: simulações romanescas de alguns espaços cotidianos: cursos e seminários no Collège de France, 1976-1977. São Paulo: Martins Fontes, 2003.

Aula. São Paulo: Cultrix, 1978.

O Rumor da Língua. Lisboa: Edições 70, 1980. 
BAUDOIN, P-A. A leitura. Reprodução de obra de arte. Paris, Museu de Artes Decorativas. In: CHARTIER, R. (org.). História da Vida Privada. São Paulo: Companhia das Letras, 1992, p. 147.

BAUMAN, Z. Modernidade Líquida. Rio de Janeiro: Jorge Zahar Ed., 2001. 254 p.

. A sociedade individualizada: vidas contadas e histórias vividas. Rio de Janeiro:

Jorge Zahar Ed., 2008. 321 p.

Books in the global dialogues of cultures. In: The Book: A World transformed. Editado por Eduardo Portella. Publicado por The United Nations Educational, Scientific and Cultural Organization, 2001.

BÍBLIA SAGRADA. São Paulo: Sociedade Bíblica do Brasil, 1993.

BONDÍA, J. L. Notas sobre a experiência e o saber de experiência. Campinas, SP: Universidade Estadual de Campinas, 2002.

BONNICI, Thomas. O Pós-colonialismo e a literatura: estratégias de leitura. Maringá, PR: Eduem, 2000. 305 p.

BORDELOIS, I. A palavra ameaçada. Rio de Janeiro: Vieira Et Lent, 2005. 112 p.

BRACKER, N. Robinson Crusoé a venir: Gertrude Stein and Roland Barthes. Romanic Review, Universidade de Columbia, janeiro-março 2000. Disponível em $<$ http:/findarticles.com/p/articles/mi_qa3806/is_200001/ai_n8881003. Acesso em: 26 fev. 2009.

BRAIT, B. A personagem. 8.ed. São Paulo: Ática, 2006. 95 p. . ( org.) Bakhtin dialogismo e construção do sentido. 2ed. rev. Campinas, SP: Editora da UNICAMP, 2005. 365 p. . (org) Bakhtin conceitos-chave. 2 ed. São Paulo: Editora Contexto, 2005. 223 p. . (org) Bakhtin outros conceitos-chave. São Paulo: Editora Contexto, 2006. 263 p.

As vozes bakhtinianas e o diálogo inconcluso. In: BARROS, D. L. P. de; FIORIN, José Luiz (orgs.). Dialogismo, Polifonia, Intertextualidade: Em torno de Bakhtin. 2ed. São Paulo, Universidade de São Paulo, 2003. 81 p.

BRANDÃO, Helena H. Nagamine. Introdução à análise do discurso. Campinas, SP: Editora da UNICAMP, 2004.

BRECHT, B. Poemas 1913-1956. 3. ed. São Paulo: Brasiliense, 1987. 328 p.

BURNS, E. M. História da Civilização Ocidental. Rio Grande do Sul: Editora Globo, 1959. v.1. $581 \mathrm{p}$.

CALDERÓN, D. E. Diccionario de términos literários. Madrid: Alianza Editorial, 2006. 
CANDIDO, A. O direito à literatura. In: CANDIDO, Antonio. Vários Escritos. 3. ed. Revista e ampl. São Paulo: Duas Cidades, 1995.

CARVALHO, D. B. A. de. A adaptação literária para crianças e jovens: Robinson Crusoé no Brasil. 2006. Tese (Doutorado). Faculdade de Letras, Pontifícia Universidade Católica do Rio Grande do Sul, Porto Alegre, 2006. Disponível em versão digital (www.pucrs.br/). Acesso em 15 set. 2008.

CERTEAU, M. de. A invenção do cotidiano: 1. Artes de fazer. Petrópolis, R.J: Vozes, 1994. $351 \mathrm{p}$.

CHARTIER, R. O Mundo como Representação. Revista Annales (nov. dez. 1989, nº 6, pp.1505-1520).

CHAUÍ, M.O que é ideologia. São Paulo: Brasiliense, 1980.

CHOMSKY, N.. Linguagem e Pensamento. Rio de Janeiro: Vozes, 1971.

CLARK, S. Pensando com Demônios: a idéia de Bruxaria no Princípio da Europa Moderna. São Paulo: EDUSP, s/d. Disponível em <http://books.google.com.br> Acesso em: 20 maio 2009.

CUNHA, A. G. da. Dicionário Etimológico da Língua Portuguesa. Rio de Janeiro: Nova Fronteira, 1982.

CUNHA, G. Uma dupla direcção da escrita em Daniel Defoe: The Farther Adventures of Robinson Crusoé, ou, alguns bons ensinamentos da má literatura. Disponível em: $<$ http://hdl.handle.net/10216/8798 >. Acesso em: 04 dez. 2008.

DEFOE, D. Robinson Crusoé. SãoPaulo: Gráfica Editora Brasileira, 1952.

Robinson Crusoé. São Paulo: Edições Cultura, 1940.

Robinson Crusoé. Portugal: Publicações Europa-América, 1975.

Robinson Crusoé. São Paulo: Brasiliense, 1994.

Robinson Crusoé. São Paulo: Brasiliense, 1983

. Robinson Crusoé. São Paulo: Companhia Editora Nacional, 2005.

. Robinson Crusoé. Lisboa: Editorial Verbo, 1960.

. Robinson Crusoe. Philadelphia: The John C. Winston Company, 1925.

. Robinson Crusoé. São Paulo: Edições de Ouro, 1970.

Robinson Crusoe. Grã-Bretanha: Penguin Popular Classics, 1994. 
. Robinson Crusoé. Rio de Janeiro. Editora Minerva, 1952.

. Robinson Crusoé. Edição Maravilhosa. Editora Brasil-América Limitada. nº 18, dezembro de 1949.

. Family Instructor. Disponível em:

<http://www.luminarium.org/eightlit/defoebib.htm $>$ Acesso em 12 dez. 2008.

. The True-Born Englisman: A Satire. Disponível em:

http://www.luminarium.org/eighlit/defoe/defoequotes.htm. Acesso em 12 jan. 2009.

The Shortest Way with Dissenters. Disponível em:

<http://www.luminarium.org/eighlit/defoe/defoequotes.htm>. Acesso em 12 jan. 2009.

DEFOE, D. Disponível em

$<$ http://academicbrooklyn.cuny.edu/englih/melani/novel_18c/defoe/index.html. Acesso em: 3 dez.2008.

DELEUZE, G. Lógica do Sentido. São Paulo: Perspectiva, 1974.

DIAS, M. C. M. O direito da criança e do educador à alegria cultural. In: Oficinas de Sonho e Realidade na formação do educador da infância. Campinas, SP: Papirus, 2003. 240 p.

DIETZSCH, M. J .M.; SILVA, M. A. S. Itinerantes e itinerários na busca da palavra. In:

Cadernos de Pesquisa. São Paulo, nº 88, p.55-63, fev.1994.

DIETZSCH, M. J. M. (org). Espaços da linguagem na Educação. São Paulo: Humanitas / FFLCH / USP, 1999.194p.

DRUMMOND, C. de A. Poesia completa e Prosa. Rio de Janeiro: Nova Aguilar, 1973.

ENCICLOPÉDIA Einaudi. Mythos/logos-Sagrado/profano. Vol. 12. Imprensa Nacional, Casa da Moeda, 1987.

. Tempo/Temporalidade. Vol. 29. Imprensa Nacional, Casa da Moeda, 1987.

. Conceito- Filosofia/filosofias. Vol. 37. Imprensa Nacional, Casa da Moeda, 1987.

Moeda, 1989.

. Homo-Domesticação-Cultura material. Vol. 16. Imprensa Nacional, Casa da

FARACO, C. A.; TEZZA, C.; CASTRO, G. de (org). Diálogos com Bakhtin. 4 ed. Curitiba, PR: Editora UFPR, 2007. 307 p.

FIORIN, J. L. Linguagem e Ideologia. São Paulo: Ática, 2006.

. Introdução ao pensamento de Bakhtin. São Paulo: Ática, 2006. 144p. 
O Romance e a Simulação do Funcionamento Real do Discurso. In: BRAIT, B.( org.) Bakhtin: dialogismo e construção do sentido. 2ed. rev. Campinas, SP: Editora da UNICAMP, 2005. 365 p.

FREGE, G. Lógica e Filosofia da Linguagem. São Paulo: Cultrix, EDUSP, 1978.

GAGNEBIN, J. M. Sete aulas sobre linguagem, memória e história. Rio de Janeiro: Imago, 1997.

Lembrar escrever esquecer. São Paulo: Editora 34, 2006. 224 p.

GANCHO, C. V. Como analisar narrativas. 9 ed. São Paulo: Ática, 2006. 79 p.

GIANETTI, Cecília. Quando a literatura invade o jornalismo. Revista Idiossincrasia.

Disponível em < http:// portalliteral.terra.com.br>. Acesso em: 13 jun. 2007.

GOULEMOT, J. M. As Práticas Literárias ou a Publicidade do Privado. In: CHARTIER, R. (org) . História da vida privada, 3: da Renascença ao Século das Luzes. São Paulo: Companhia das Letras, 1991. p. 371-405.

HEIDRICH, Á. L. O pensamento capitalista em Robinson Crusoé. Revista Vidya, n 14, p. 17-34. Editora Palotti. Sta Maria, 1995.

HELD, J. O Imaginário no Poder: as crianças e a literatura fantástica. São Paulo: Summus, 1980. $239 \mathrm{p}$.

HOLQUIST, M. The Dialogic Imagination Four Essays by M. M. Bakhtin - edited by Michael Holquist, translated by Caryl Emerson and Michael Holquist . Texas: University of Texas Press, 1992.

LAJOLO, M. Sociedade e Literatura: Parceria sedutora e problemática. In: ORLANDI, E. P.; LAJOLO, M.; IANNI, O. Sociedade e Linguagem. Campinas, SP: Unicamp, 1997.

LEBRUN, F. As Reformas: devoções comunitárias e piedade pessoal. In: CHARTIER, R. (org). História da vida privada, 3: da Renascença ao Século das Luzes. São Paulo: Companhia das Letras, 1991.p. 71-111.

LEITE, L. C. de M. O foco narrativo. São Paulo: Ática, 1985.

LOPES, E. Discurso Literário e Dialogia em Bakhtin. In: BARROS, D. L. P. de; FIORIN, José Luiz (orgs.). Dialogismo, Polifonia, Intertextualidade: Em torno de Bakhtin. 2ed. São Paulo, Universidade de São Paulo, 2003. 81 p.

MANGUEL, A. The library of Robinson Crusoe. In: The Book: A World transformed. Editado por Eduardo Portella. Publicado por: The United Nations Educational, Scientific and Cultural Organization, 2001.

MAINGUENEAU, D. O contexto da obra literária. São Paulo: Martins Fontes, 2001. 202 p. Gênese dos discursos. Paraná: CRIAR Edições, 2005. 
MIOTELLO, W. Ideologia. In: BRAIT, B. (org) Bakhtin conceitos-chave. 2 ed. São Paulo: Editora Contexto, 2005. 223 p.

MITOLOGIA. São Paulo: Abril Cultural, s.d., vol.2.

OLSON, D. O mundo no papel: as implicações conceituais e cognitivas da leitura e da escrita. São Paulo: Ática, 1997. 341 p.

ORLANDI, E. P. As formas do silêncio: no movimento dos sentidos. 6 ed. Campinas, SP: Editora da UNICAMP, 2007. 181 p.

1987.

. A linguagem e seu funcionamento - as formas do discurso. Campinas, SP: Pontes,

OSAKABE, H. Linguagem e Educação. In: MARTINS, M. H. (org). Questões de

Linguagem. São Paulo: Contexto, 1991.

PÊCHEUX, M. Semântica e Discurso: uma crítica à afirmação do óbvio. Campinas, SP: UNICAMP, 1988.

PIATELLI-PALMARINI, M. (org.). Teorias da linguagem, teorias da aprendizagem: 0 debate entre Jean Piaget \& Noam Chomsky. Tradução de Álvaro Cabral. São Paulo: Cultrix, Ed. da Universidade de São Paulo, 1983.

POTTER R. Expressando sua enfermidade: a linguagem da doença na Inglaterra georgiana. In: BURKE, P.; POTTER, R. (org). Linguagem, Indivíduo e Sociedade: história social da linguagem. São Paulo: Editora da Universidade Federal Paulista, 1993.

QUEIROZ, J. M. de. Em busca de romances: um passeio por um catálogo da Livraria Garnier. In: ABREU, M. (org). Trajetórias do Romance: circulação, leitura e escrita nos séculos XVIII e XIX. Campinas, SP: Mercado das Letras, 2008. (Coleção Histórias de Leitura).

REVEL, J. Os usos da civilidade. In: CHARTIER, R. (org). História da vida privada, 3: da Renascença ao Século das Luzes. São Paulo: Companhia das Letras, 1991.p. 170-209.

ROBERT, Marthe. Romance das origens, origens do romance. São Paulo: Cosac Naify, 2007. $280 \mathrm{p}$.

SANTAELLA, L. Estética: de Platão a Peirce. São Paulo: Experimento, 1994.

SAVATER, F. A Infância Recuperada. São Paulo: Martins Fontes, 2001.

SCHAPOCHNIK, N. Sobre a leitura e a presença de romances nas bibliotecas e gabinetes de leitura brasileiros. In: ABREU, M. (org). Trajetórias do Romance: circulação, leitura e escrita nos séculos XVIII e XIX. Campinas, SP: Mercado das Letras, 2008. (Coleção Histórias de Leitura).

SILVA, O. de A. Lugares de compra, itinerários de leitura: circulação de romances em Fortaleza oitocentista. In: ABREU, M. (org.). Trajetórias do Romance: circulação, leitura e 
escrita nos séculos XVIII e XIX. Campinas, SP: Mercado das Letras, 2008. (Coleção Histórias de Leitura).

STEINER, G. Linguagem e Silêncio: ensaios sobre a crise da palavra. São Paulo: Companhia da Letras, 1988.

Letras, 1990.

Extraterritorial: a literatura e a revolução da linguagem. São Paulo: Companhia das

TODOROV, T. Mikhaïl Bakhtine Le Principe Dialogique: suivi de Écrits du Cercle de Bakhtine. Paris: Éditions Du Seuil, 1981.

A vida em comum: Ensaio de Antropologia geral. Campinas, SP: Papirus, 1996.

Nós e os Outros: a reflexão francesa sobre a diversidade humana. Rio de Janeiro:

Jorge Zahar Ed., 1993. 215 p.

O espírito das Luzes. São Paulo: Editora Barcarolla, 2008. 157 p.

VERMEER, J. Mulher Pesando Ouro. Representação de obra de arte. In: DORE, H. A Arte dos Retratos. Rio de Janeiro: Ediouro, 1996.79 p.

VILlALTA, L. C. Robinson Crusoé, de Daniel Defoe: da sua circulação no mundo lusobrasileiro ao seu diálogo com o devir histórico. In: I Seminário Brasileiro sobre Livro e História Editorial. Realização FCRB-UFF/PPGCOM-UFF/LIHED - de 8 a 11 de novembro de 2004 - Casa Rui Barbosa - RJ - Brasil. Disponível em: <www.caminhosdoromance.iel.unicamp.br/estudos/ensaios/crusoe.pdf>). Acesso em: 22 fev. 2007.

VYGOTSK, L. S. Pensamento e Linguagem. São Paulo: Martins Fontes, 1991.

WATT, Ian. Mitos do individualismo moderno: Fausto, Dom Quixote, Dom Juan, Robinson Crusoé. Rio de Janeiro: Jorge Zahar Editora, 1997.

WOOLF, Virginia. O leitor comum. Rio de Janeiro: Graphia, 2007. 135 p. 

Parte 6 

Anexo A

\section{Poema}

Apague as pegadas

Bertolt Brecht 



\section{Apague as pegadas}

Bertolt Brecht

Separe-se de seus amigos na estação

De manhã vá à cidade com o casaco abotoado

Procure alojamento, e quando seu camarada bater:

Não, oh, não abra a porta

Mas sim

Apague as pegadas!

Se encontrar seus pais na cidade de Hamburgo ou em outro lugar Passe por eles como um estranho, vire na esquina, não os reconheça Abaixe sobre o rosto o chapéu que eles lhe deram

Não, oh, não mostre seu rosto

Mas sim

Apague as pegadas!

Coma a carne que aí está. Não poupe.

Entre em qualquer casa quando chover, sente em qualquer cadeira Mas não permaneça sentado. E não esqueça seu chapéu.

Estou lhe dizendo:

Apague as pegadas!

O que você disser, não diga duas vezes.

Encontrando o seu pensamento em outra pessoa: negue-o.

Quem não escreveu sua assinatura, quem não deixou retrato

Quem não estava presente, quem nada falou

Como poderão apanhá-lo?

Apague as pegadas!

Cuide, quando pensar em morrer

Para que não haja sepultura revelando onde jaz

Com uma clara inscrição a lhe denunciar

$E$ o ano de sua morte a lhe entregar

Mais uma vez:

Apague as pegadas!

(Assim me foi ensinado.) 

Anexo B

\section{Robinson Crusoé em diferentes culturas}





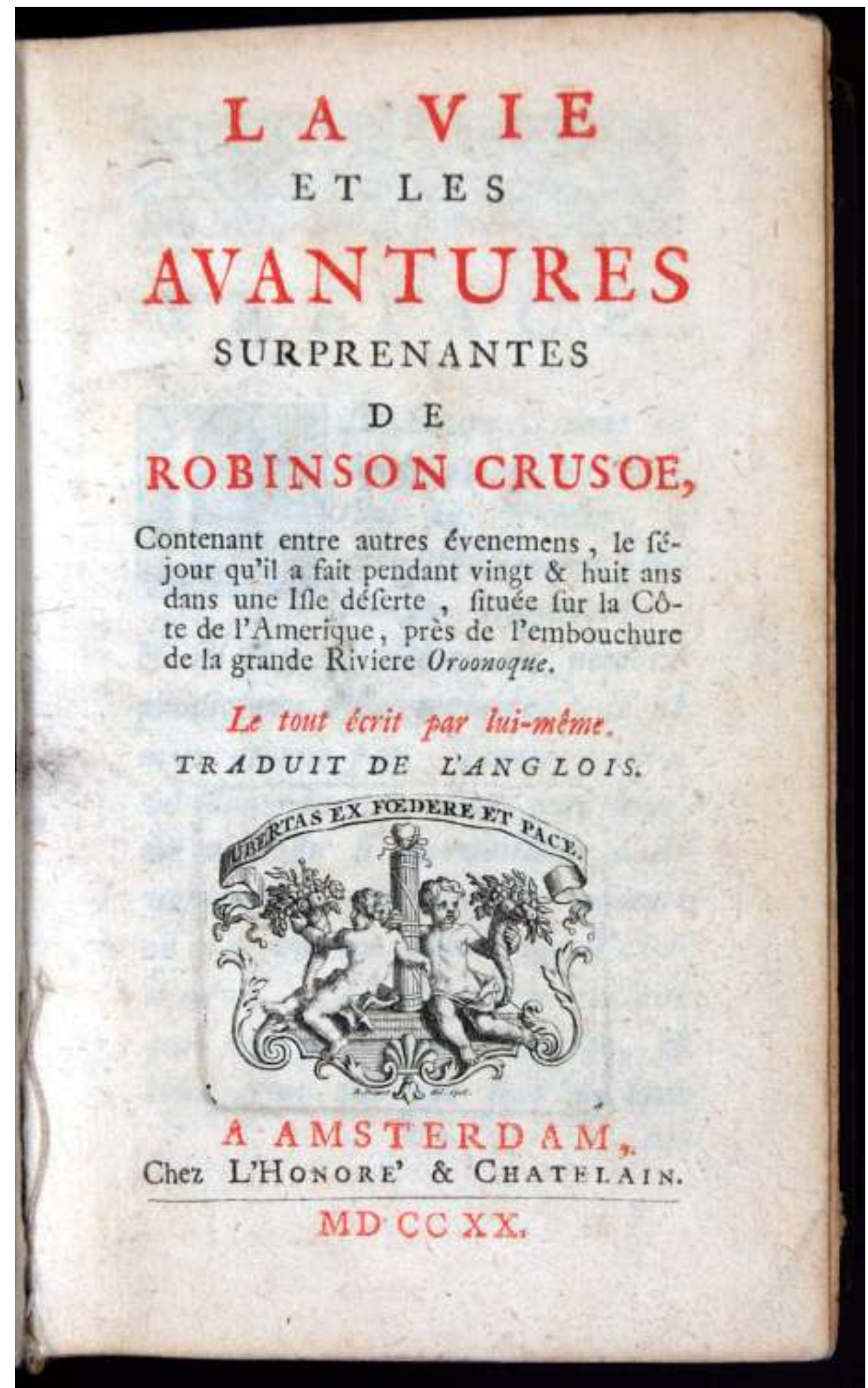




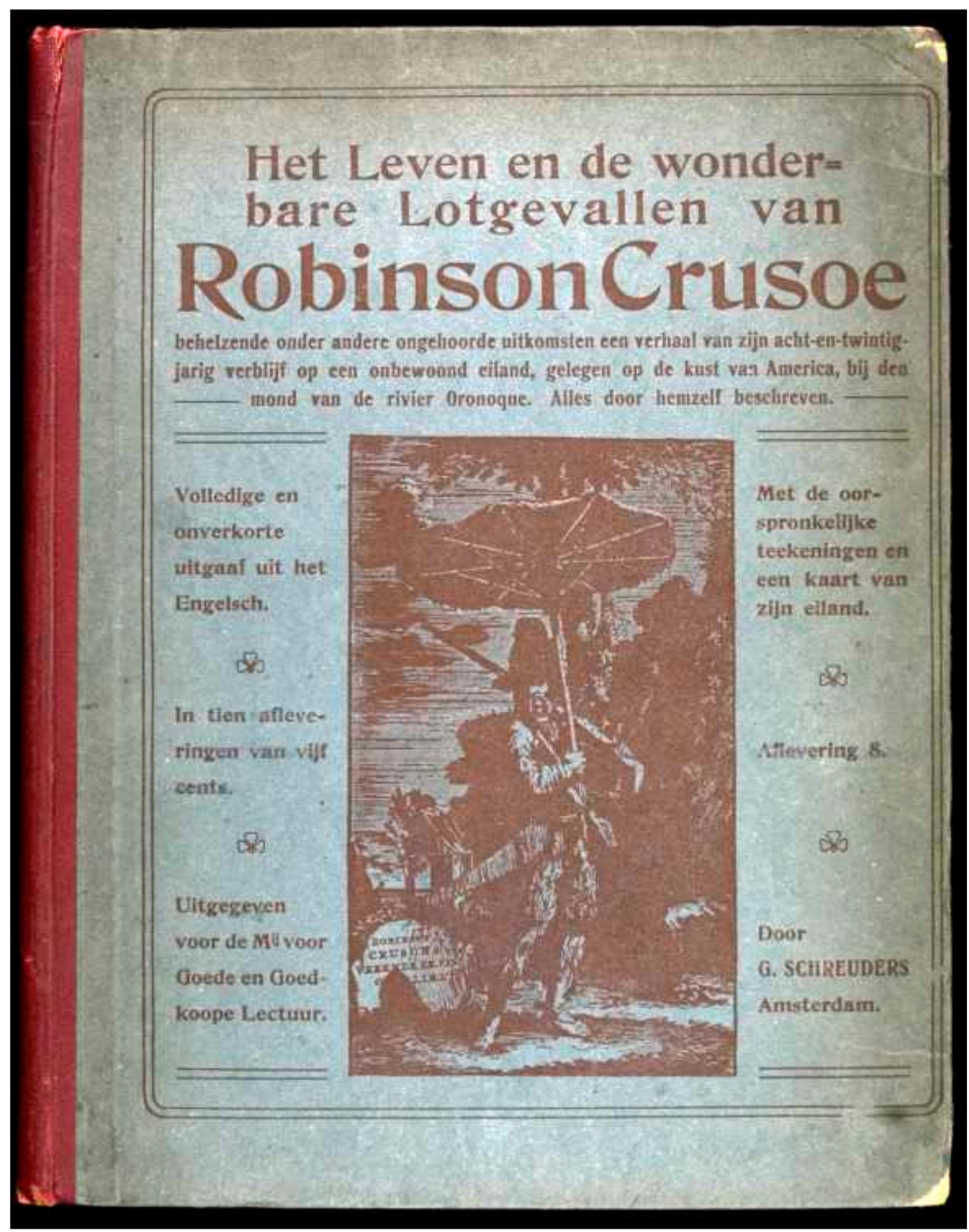




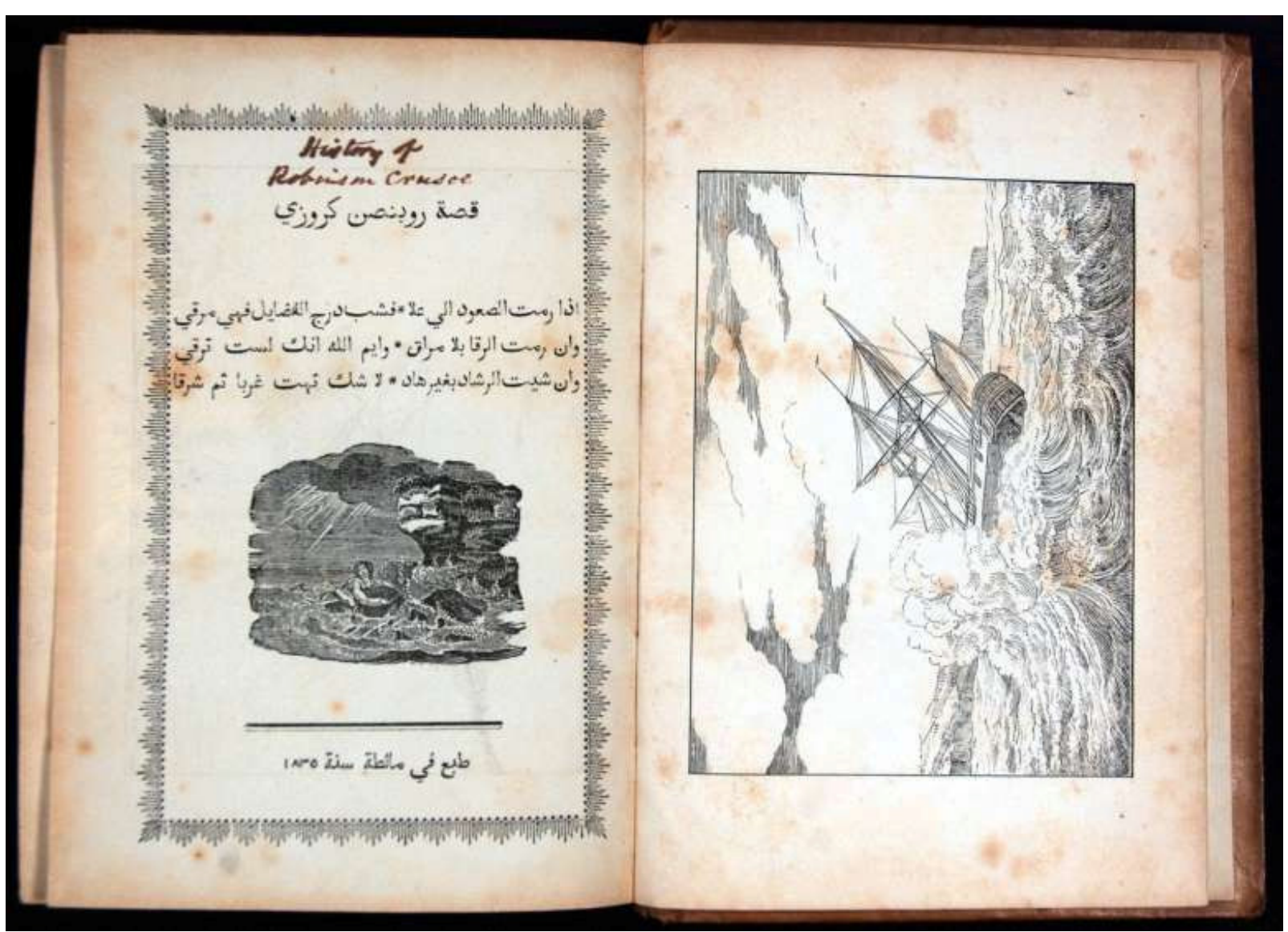




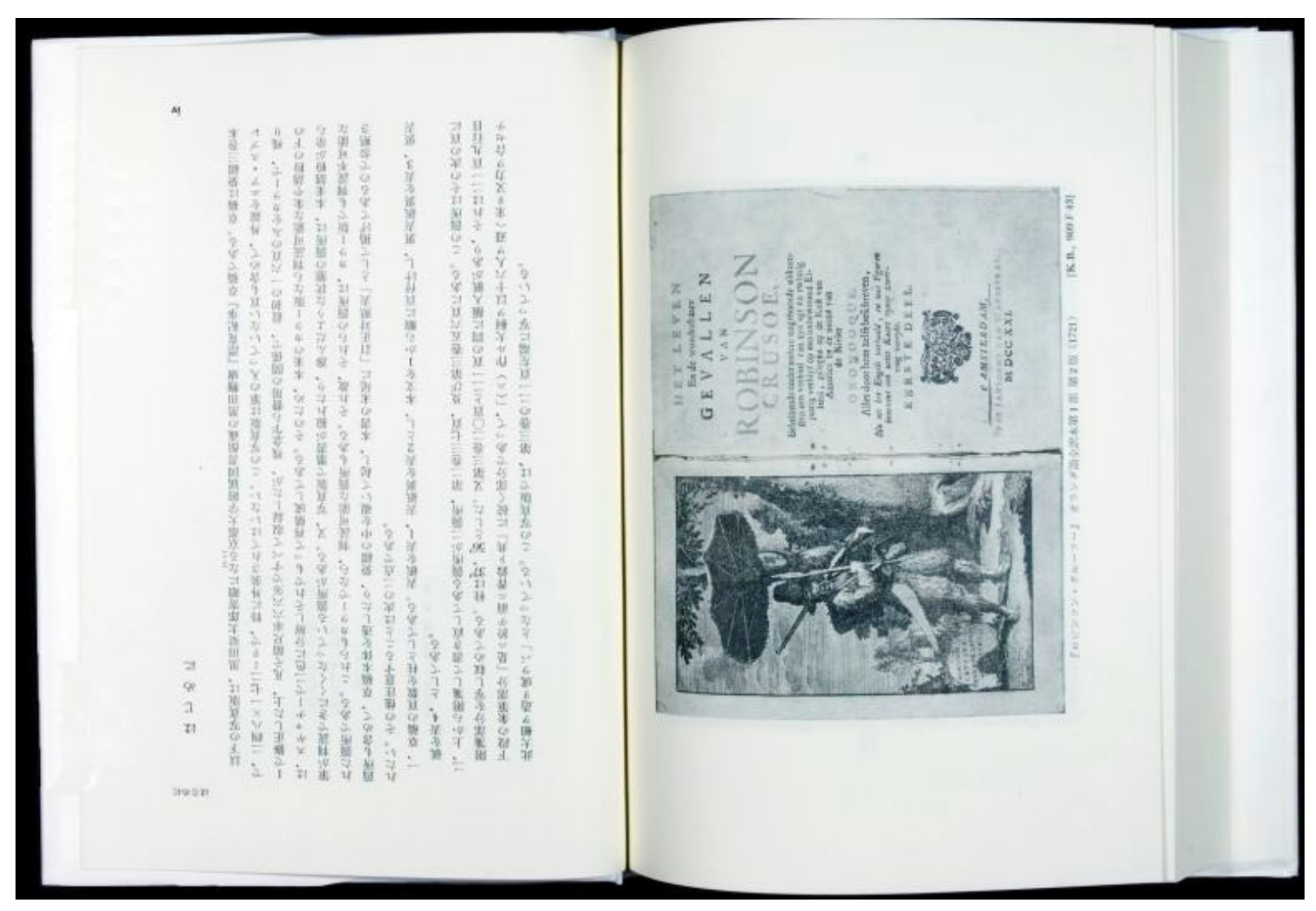


Anexo C

Atos de linguagem 



\section{ENUNCIAÇÕES}

\section{Pensamentos}

Comecei a pensar [...] então reuni o conselho, quer dizer, no meu pensamento, se devia levar a jangada $[\ldots]$ (p. 58).

Mas devo primeiro falar um pouco de mim e dos meus pensamentos acerca da vida, que se pode supor não seriam poucos [...] e algumas vezes discutia comigo próprio, porquê [sic] a Providência [...] (p. 66).

Mas algo vinha sempre rapidamente contrapor-se a estes pensamentos e repreender-me [...] (p.67).

[...] comecei a recriminar-me sobre a minha vida passada [...] provocando a justiça de Deus [...] para [...] lidar comigo de uma maneira tão vingativa. Estas reflexões [...] arrancaram-me algumas palavras, como rezar a Deus [...] (p. 93).

Estava embebido nestes pensamentos, como alguém aparvalhado, e não tinha palavra para dizer, ou, melhor, para responder a mim próprio [...] (p. 96).

[...] os meus pensamentos voltavam sempre à frase "salvar-te-ei" (p. 98).

E, se nada acontece sem Ele saber, Ele sabe que eu estou aqui [...] Ele determinou que tudo isto me acontecesse.

Nada me veio à ideia que pudesse contradizer nenhuma destas conclusões (p. 95).

Comecei a entender as palavras num sentido diferente do que lhe tinha dado antes (p.99).

[...] e que Ele tinha preenchido todas as deficiências do meu estado de isolado e do meu desejo de companhia humana, pela Sua presença e pela comunicação da Sua graça à minha alma, amparando-me, confortando-me e encorajando-me a depender da Sua providência aqui e a ter esperança na Sua eterna presença mais tarde (p. 113).

Mas agora comecei a ter novos pensamentos; diariamente, leio a palavra de Deus [...] uma manhã, estando muito triste, abri a Bíblia nestas palavras: Eu nunca, nunca te abandonarei, nem te esquecerei; imediatamente, vi que estas palavras eram para mim; para quem mais poderiam ser, dirigidas desta forma, mesmo no momento em que me lamentava da minha situação, como alguém esquecido por Deus e pelos homens? "Bom", disse eu, "se Deus não me esquece, que más consequiências poderá ter, ou que interesse tem, que o mundo me esqueça, vendo, por outro lado, que, se tivesse todo o mundo e devesse perder o favor e a bênção de Deus, não haveria comparação possível na perda?” (p.114). 
[...] enquanto fazia o barco [...] Encantei-me com o planeá-lo, sem me preocupar se seria capaz de executá-lo; não que a dificuldade de pô-lo a navegar me não viesse várias vezes à ideia, mas pus um travão às minhas próprias interrogações, com esta tola resposta que dei a mim mesmo: "Vamos primeiro fazê-lo, garanto que descobrirei uma maneira ou outra de pôlo a flutuar quando pronto" (p. 126).

E assim ia vivendo confortavelmente, [...] Isto tornava a minha vida melhor do que a vida social, pois, quando sentia necessidades de conversar, perguntava-me se o dialogar com os meus próprios pensamentos e, como espero poder dizer, mesmo com Deus, através de jaculatórias, não seria melhor que o maior divertimento da sociedade humana (p. 135).

Concluí que devia ser um ente muito mais perigoso, ou seja, que devia ser algum dos selvagens (p.153)

[...] pensei que este era o estado de vida que a infinitamente ponderada e boa Providência Divina tinha escolhido para mim, e que não podia determinar os objetivos de divina sabedoria [...] direito devido à criação de pôr e dispor de mim dum modo absoluto, como Ele o decidisse $[\ldots]$ (p.154).

Tendo chegado a esta conclusão, passei a ir para o meu trabalho na colheita com muito mais à-vontade (p. 177).

Concluí que a expectativa do mal é pior do que sofrê-lo (p. 178).

Gastei a maior parte do meu tempo [...] pensando em como é que lhes havia de cair em cima [...] (p. 178).

[...] estava a ler a Bíblia, mergulhado em profundos pensamentos acerca da minha situação actual (p. 179).

Tive presença de espírito [...] para pensar que, embora eu não os pudesse ajudar, me poderiam eles ajudar a mim (p. 179).

Estes pensamentos oprimiram-me tanto que comecei querer desistir da empresa [...] (p. 183).

[...] sentei-me num montículo, muito pensativo e ansioso [...] Estava a pensar [...] (p. 183).

Vivi assim durante mais dois anos, mas a minha infeliz cabeça estava sempre pronta a fazerme saber que existia, para tornar meu o corpo miserável. Esteve estes dois anos cheia de projectos e intenções de como seria possível eu sair da ilha (p.187).

[...] estava sempre a matutar nos meios e possibilidades de me escapar deste lugar (p. 188).

É tão impossível como inútil indicar a infinidade de pensamentos que passaram por esta grande avenida do cérebro que é a memória, nesta noite: passei em revisão toda a história da minha vida, condensada ou abreviadamente, até ao momento da minha chegada à ilha, e também da parte da minha vida desde que cá cheguei (p. 189).

Na minha reflexão sobre o meu caso [...] comparei a maneira feliz com que tinha resolvido os meus assuntos nos primeiros anos de estada, comparada com a ansiedade, o medo e as 
precauções em que tenho vivido desde que vi aquela pegada na areia. [...] Isto forneceu matéria para o meu pensamento para conclusões muito úteis [...] (p. 189).

Depois de me ter debruçado um certo tempo sobre estes pensamentos, comecei a meditar seriamente no perigo real [...] (p. 189).

Quando acabei de pensar nisto, o meu espírito passou a dedicar-se à natureza destas miseráveis criaturas, quero dizer, os selvagens, e como é que era possível acontecer no mundo que o sábio Governador de todas as coisas pudesse dar a algumas das Suas criaturas tanta desumanidade (p.190).

O meu cérebro estava unicamente absorvido pela ideia de chegar com o barco ao continente (p. 190).

Quando isto já se tinha apossado dos meus pensamentos por duas ou mais horas, com tal violência que me tinham posto o sangue a ferver e o meu pulso a bater de tal modo que parecia que estava com febre, unicamente devido ao desejo que me possuía, a natureza, como se eu estivesse fatigado só de o pensar, mergulhou-me num sono profundo (p. 191).

Disse para comigo: "Agora posso certamente aventurar-me para o continente, porque este amigo vai servir-me de piloto, dir-me-á o que fazer, onde arranjar provisões, e onde não ir, pelo receio de ser devorado, quais os lugares onde posso ir e quais os que devo evitar" (p. 191).

Disto tudo, todavia, tirei uma conclusão [...] (p. 191).

[...] depois de uma luta íntima e de bastantes hesitações, visto que todos estes argumentos se debateram na minha cabeça durante bastante tempo [...] (p.192).

[...] o pensamento de verter sangue humano para me salvar era-me terrível, de tal forma que não me pude reconciliar comigo próprio durante bastante tempo (p. 193).

Isto deu origem, várias vezes, a que eu reflectisse, com admiração, em que Deus tenha querido, na sua providência e na direcção de todas as coisas, tirar a uma grande parte dos seus súbditos o melhor uso para o qual as suas faculdades e as potencialidades de alma estão adaptados, se bem que lhes tenha dado a mesma força, a mesma razão, as mesmas afeições, os mesmos sentimentos de carinho e dever [...] e toda capacidade de fazerem o bem e de o receberem, que Ele nos deu a nós. E que, quando Lhe apetece, lhes dá ocasião para que os exerçam, eles estão [...] mais preparados para os aplicar no sentido correcto para que lhes foram dadas, do que nós [...] embora estivéssemos iluminados pela suprema luz da instrução o espírito de Deus - e pelo conhecimento da Sua Palavra, adicionados aos nossos conhecimentos (p. 200/2001).

Mas eu dava por findos os meus pensamentos, confrontando-os com estas conclusões: (primeira) que nós não sabíamos sob que ponto de vista e em relação a que lei é que isto podia ser condenado [...] devia ser por causa de terem pecado contra essa luz [...] e, (segunda), como todos nós éramos o barro nas mãos do oleiro, nenhum pote poderia dizer-lhe: "Porque é que vós me fizestes assim?" (p. 201). 


\section{Declarações}

Tivesse eu sido suficientemente sensato para ter voltado para Hull e para casa, seria feliz e o meu pai, a exemplo da parábola do nosso Salvador, teria mesmo morto a vitela mais gorda para mim (p.22).

Robinson Crusoé afirma ter que começar a relação melancólica duma cena de vida silenciosa (p.68).

[...] e aqui devo notar que, se a razão é a substância e a origem da matemática, também, expondo e observando tudo com a razão e fazendo das coisas os julgamentos mais racionais, todo homem pode, com o tempo, dominar qualquer profissão (p. 72).

Não me recordo de em todo este tempo ter tido um único pensamento virado a Deus, ou sequer uma reflexão íntima sobre o meu destino (p. 91).

Agia como um mero inconsciente, segundo os princípios da natureza e pelo imperativo do senso comum (p.91).

"Deus! quão miserável sou! Se ficar doente, morrerei, por certo, por falta de auxílio, e o que será de mim!" (p. 93).

"Agora", disse em voz alta, "as palavras do meu querido pai pertencem ao passado: a justiça de Deus alcançou-me [...]” (p. 93).

"Então gritei: 'Deus, ajuda-me, porque estou em grande aflição!”’ (p. 94).

Esta foi a primeira vez que pedi a Deus que abençoasse a minha comida [...] (p. 94).

[ ...] fiz o que nunca tinha feito na minha vida: ajoelhei-me e rezei a Deus para que cumprisse sua promessa para comigo, de que, se $\mathrm{O}$ chamasse num momento de aflição, Ele me salvaria; $[\ldots]($ p. 97).

[...] em voz alta agradeci a Deus o ter-me recuperado da doença (p. 98).

A impressão causada pelo sonho reavivou-se e as palavras "Tudo isto não lhe indicou o arrependimento" estavam sinceramente no meu espírito. Estava sinceramente pedindo a Deus para me dar arrependimento, quando aconteceu providencialmente nesse dia que, ao ler as escrituras, chegasse a estas palavras: Ele é glorificado como Príncipe e Salvador, para dar o arrependimento e para dar o perdão (p. 98).

[...] gritei em voz alta: “Jesus, filho de David, Jesus, glorificado Príncipe e Salvador, dá-me o arrependimento!" (p. 99).

[...] dou sinceramente graças a Deus por me ter aberto os olhos, mesmo através das desgraças [...] (p. 114). 
Por um constante estudo e séria aplicação da palavra de Deus e pela assistência da Sua graça, eu ganhara um conhecimento diferente daquele que tinha antes. Eu albergava noções diferentes das coisas. Olhava para o mundo como uma coisa remota [...] (p. 128).

[...] e, se o posso dizer, como Pai Abraão a Divas, Entre mim e ti há um grande abismo (p. 128).

“Oh, deserto feliz, não mais te verei! (p. 138).

Quando cheguei, caí de joelhos e dei graças a Deus por me ter salvo (p.140).

Daria um sorriso estoico, ter-me visto à mesa, com a minha pequena família, sentados a jantar (p. 146).

“enfiei-me nele como alguém perseguido" (p. 152).

\section{Sobre a pegada ...}

Pensava que Satã teria tomado forma humana neste local [...] facilmente imaginado por alguém que saiba o que é viver no receio constante do seu semelhante (p. 160).

A oração é um ato do espírito (p. 160).

[...] eu sentia uma repulsa tão grande por estes miseráveis selvagens [...] e do vil e desumano costume de se devorarem uns aos outros [...] a aversão que tinha a esses miseráveis diabólicos, e tinha mais receio de ver um deles do que o Diabo propriamente dito (p. 162).

[...] estas ordens secretas da Providência. Venham de onde vierem [...] são uma prova da existência dos espíritos e da secreta comunicação entre os vivos e o além [...] (p. 171).

Mas estava escrito que não era assim (p.175).

Não esquecendo de me recomendar à divina protecção e rezar a Deus para me defender dos bárbaros (p. 176).

Não encontro palavras suficientemente fortes para exprimir os desejos que se entrechocavam no meu espírito, ao ver isto, dizendo: "Ah, se ao menos estivesse aqui um ou dois. Não, ao menos uma alma que se tivesse salvo deste barco, que tivesse chegado até mim, para que eu tivesse um companheiro, um meu semelhante que falasse comigo e com quem eu pudesse conversar também” ( p. 181).

"Ao menos, um!" Acredito que repeti as palavras "ao menos, um" mil vezes. E a minha ânsia era tal que minhas mãos se enclavinhavam e os meus dedos premiam as palmas das mãos de tal forma que, se tivesse algo mole na mão, tê-lo-ia esmagado involuntariamente (p. 182).

Era, sem dúvida, o efeito de um desejo ardente e de ideias formadas no meu cérebro [...] (p. 182).

[...] pedindo a Deus para me proteger na viagem, parti (p. 183). 
[...] doença geral da humanidade [...] não se estar satisfeito com a posição em que Deus e a natureza nos situam. Senão olhem para a minha situação inicial e para os excelentes conselhos do meu pai, podendo eu chamar o meu pecado original o não os ter seguido [...] (p. 187).

[...] fazer agora o relato das minhas primeiras concepções sobre os esquemas loucos da minha fuga, e como e sob que bases agi (p. 188).

[...] comecei a pedir à Providência para salvar a vida desta criatura (p. 194).

Saudei em voz alta (p. 195).

Ensinei-lhe também a dizer Patrão, e fi-lo saber que esse era o meu nome; ensinei-lhe também a dizer sim e não, bem como o seu significado (p. 198).

Foi o mais agradável ano da minha vida neste local. [...] Em resumo, comecei a dar uso à língua, o que, na realidade, pouca ocasião tinha para fazer anteriormente, claro que a falar (p. 204).

[...] um encadeado de milagres [...] mostravam à saciedade a existência dum poder secreto da Providência para governar o mundo e evidenciavam que, com o Seu infinito poder, tinha possibilidade, quando queria, de olhar e auxiliar os míseros, mesmo nos recantos mais perdidos do mundo (p. 258).

Numa palavra, eu estava numa situação que mal podia compreender, nem sabia como comportar-me, devido à alegria que tinha (p. 269).

\section{Perguntas}

[...] quando a razão me rebateu da seguinte forma: bom, estás numa situação desolada é verdade, mas, faz favor de te lembrar, onde estão os outros? Não vinham onze no escaler? Onde estão os dez? Porque [sic] não se salvaram eles e te perdeste tu? Porque [sic] estás só? É melhor estar aqui ou ali? (p.67).

[...] O que me teria acontecido se tivesse de viver nas condições em que primeiramente cheguei a terra, sem o necessário para viver, ou o necessário para armazenar e procurar obtêlo? Principalmente, disse em voz alta (se bem que para mim), o que teria feito sem uma arma, sem munições, sem nenhuma ferramenta para fazer qualquer coisa, ou para trabalhar, sem roupas, colchões, barraca ou qualquer coisa para me cobrir? (p. 67)

\section{Vieram-me à ideia pensamentos como estes:}

O que era esta terra e mar de que já tinha visto tanto? De que modo foram feitos? E o que era eu e todos os outros seres, selvagens ou mansos, humanos ou animais? Como tínhamos aparecido? (p. 95). 
Porquê [sic] me tinha Deus feito isto? Que tinha eu feito para ser assim tratado? (p. 95).

"Pode Deus pôr uma mesa no descampado?", e, assim, comecei a dizer: "Pode Deus livrarme deste lugar?” (p. 97).

[...] e, então, perguntei a mim mesmo coisas deste jaez: não tinha sido salvo, e maravilhosamente, da doença?, da mais triste condição possível, e que me metia tanto medo? e que tinha eu feito? Tinha feito a minha parte? Deus tinha-me livrado, mas eu não o tinha glorificado; quer dizer, não tinha recebido e sido grato por isto como uma salvação; como podia então esperar salvamentos maiores? (p. 98).

"Como consegues ser tão hipócrita", disse, de forma audível, "pretender que estás grato por uma situação da qual fazes o possível por te contentares, embora queiras rezar convictamente para te livrarem dela?" (p. 114).

Abati um cedro: pergunto-me se Salomão alguma vez teve um semelhante para a construção do templo de Jerusalém (p. 126).

Eu tinha o suficiente para comer e para suprir as minhas necessidades; que era todo o resto para mim? (p. 128).

Oh, miserável criatura "Para onde vou?" (p. 138).

Por que haveria outra coisa com forma humana de vir a este lugar? Onde estava o barco que os tinha trazido? Como havia só uma marca? Como é que era possível um homem vir até ali? (p. 152).

Que autoridade tinha eu para pretender ser juiz e executor destes homens como criminosos, homens que os Céus tinham resolvido manter impunes durante várias gerações e fazer deles, ao fim e ao cabo, os executores dos Seus desígnios? Em que medida eram eles réus, perante mim? E que direito tinha eu de intervir nesta querela, em que o sangue era vertido por eles? Debati várias vezes comigo mesmo o seguinte: como é que eu sabia o que Deus julgava deste caso particular? (p. 166-167).

Que é que eu tinha que abandonar uma razoável fortuna, uma boa plantação, que estava a melhorar a todo momento, para ir à Guiné caçar negros, quando o tempo e a paciência teriam aumentado as nossas reservas de forma a que pudéssemos comprá-los ao pé da porta, àqueles cujo ofício era exactamente trazê-los? (p. 188).

\section{Especulações / Conjecturas}

Em que parte do mundo viviam os selvagens? A que distância da costa estavam quando vinham? Como é que eles se aventuravam tão longe de casa? Que qualidade de barcos tinham? Porque é que eu não poderia arranjar-me de forma a ir até lá, como eles vinham para cá? (p. 190). 
[... ] depois de terem visto a luz, eles teriam embarcado no escaler e tentado fazer-se a terra, mas, como o mar estava muito bravo, podiam ter ido naufragar mais longe. Outras vezes pensei que tivessem perdido o escaler [... ] Também imaginei que eles teriam outro barco [...]. (p. 180).

\section{Invocações}

Rezei outra vez a Deus [...] não sabia o que dizer ;[...] e gritava: "Deus, olhai por mim, Deus, tende piedade de mim, Deus tende dó de mim!" (p. 90).

[...] e, nesta confusão de alma, não sabia o que a minha boca dizia; mas eram principalmente exclamações do gênero: "Deus!, quão miserável sou! Se ficar doente, morrerei, por certo, por falta de auxílio, e o que será de mim!" (p.93).

Então gritei: "Deus, ajuda-me, porque estou em grande aflição!” (p. 94).

\section{Palavras da Bíblia}

Chama-me no momento de aflição, e salvar-te-ei, e então darás graças (p.96).

“Pode Deus pôr uma mesa no descampado?”(p. 97).

"salvar-te-ei" (p. 98).

Ele é glorificado como Príncipe e Salvador, para dar o arrependimento e para dar o perdão (p.98).

Eu nunca, nunca te abandonarei, nem te esquecerei (p. 114).

Entre mim e ti há um grande abismo (p. 128).

“Crê no Senhor e anima-te, Ele dar-te-á forças; crê, repito, no Senhor”(p. 155).

\section{Livro de Jonas:}

1 Veio a palavra do Senhor a Jonas, filho de Amitai, dizendo:

2 Dispõe-te, vai à grande cidade de Nínive e clama contra ela, porque a sua malícia subiu até mim. 
3 Jonas se dispôs, mas para fugir da presença do Senhor, para Társis; e tendo descido a Jope, achou um navio que ia para Társis; pagou, pois, a sua passagem e embarcou nele, para ir com eles para Társis, para longe da presença do Senhor.

4 Mas o Senhor lançou sobre o mar um forte vento, e fez-se no mar uma grande tempestade, e o navio estava a ponto de se despedaçar.

5 Então, os marinheiros, cheios de medo, clamavam cada um ao seu deus e lançavam ao mar a carga que estava no navio, para o aliviarem do peso dela. Jonas, porém, havia descido ao porão e se deitado; e dormia profundamente.

6 Chegou-se a ele o mestre do navio e lhe disse: Que se passa contigo? Agarrado no sono? Levanta-te, invoca o teu deus; talvez, assim, esse deus se lembre de nós para que não pereçamos.

7 E diziam uns aos outros: Vinde e lancemos sortes, para que saibamos por causa de quem sobreveio este mal. E lançaram sortes, e a sorte caiu sobre Jonas.

8 Então, lhe disseram: Declara-nos, agora, por causa de quem nos sobreveio este mal. Que ocupação é a tua? Donde vens? Qual a tua terra? E de que povo és tu?

9 Ele lhes respondeu: Sou hebreu e temo ao Senhor, o Deus do céu, que fez o mar e a Terra.

10 Então, os homens ficaram possuídos de grande temor e lhe disseram: Que é isto que fizeste! Pois sabiam os homens que ele fugia da presença do Senhor, porque lho havia declarado (p. 886).

\section{Vozes:}

Sonhei [...] que vi um homem descer numa nuvem grande e negra, no meio de uma chama muito viva [...] seu aspecto era o mais aterrorizador que imaginar se possa [...] e o ar parecia [...] como se tivesse sido cheio de línguas de fogo. [...] falou-me, e eu ouvi uma voz tão terrível [...] tudo o que posso dizer ter percebido foi: "Vendo que tudo isto não te indicou o arrependimento, então deves morrer!” (p. 90).

A minha consciência atacou-me nesta pergunta - Porquê [sic] me tinha Deus feito isto? Que tinha eu feito para ser assim tratado? - , como se tivesse blasfemado, e pareceu-me que me falou como se fosse uma voz exterior: "MISERÁVEL!, perguntas o que fizeste? Olha para trás, nessa vida mal gasta, e pergunta o que não fizeste; pergunta: 'Porque [sic] não fui ainda destruído? Porque é que não me afoguei em Yarmouth, não pereci na luta quando o barco foi tomado pelos piratas de Sallee, devorado pelas feras na costa da África ou afogado aqui, quando toda a tripulação morreu, menos tu? E perguntas: 'Que fiz eu?'” (p. 95).

[...] fui acordado por uma voz chamando-me pelo meu nome várias vezes: "Robin, Robin, Robin Crusoé, pobre Robin Crusoé, onde estás, Robin Crusoé? Onde estás? Onde estiveste?" (p. 141). 
[...] pensei ter sonhado com alguém a falar comigo, mas, como a voz continuava a repetir: "Robin Crusoé, Robin Crusoé”[...] (p. 141).

Mas, mal abri os olhos, vi o meu papagaio Poll empoleirado no topo da cerca, imediatamente percebi que era ele que me tinha falado [...] (p, 141).

“Pobre Robin Crusoé, onde estás? Onde estiveste? Como chegaste aqui?" e outras coisas semelhantes que eu lhe ensinei (p. 141).

Tinha a certeza de que não podia ser ninguém além do honesto Poll [...] e continuou a falarme: "Pobre Robin Crusoé! Como vieste? Onde estiveste?" tal como se estivesse transbordante de alegria por me voltar a ver [...] ( p. 142).

Quando estamos numa encruzilhada [...] uma voz interior dirige-nos num sentido quando pensávamos em ir no outro ( p. 170).

\section{Interlocutores}

[...] estava em cima de uma das arcas um animal semelhante a um gato selvagem, o qual, quando me aproximei dele, fugiu para perto e ficou quieto; ficou muito quieto e indiferente, e olhava-me directamente [sic] para a cara, como se pensasse em travar conhecimento comigo.[...] lhe dei um bocadinho de biscoito, embora não tivesse muito, [...] ele aproximouse, cheirou-o, comeu-o e procurou (como que agradado) mais, mas eu agradeci-lhe [...] (p.59).

À vista deste dinheiro, sorri para mim mesmo. 'Porcaria', disse em voz alta. 'que utilidade tens? Embora valioso, para mim não vales o trabalho de me baixar para te apanhar; uma destas facas vale mais do que todas estas moedas; não tenho forma de te dar uso, por isso fica aí, se bem que valioso, e vai para o fundo como animal cuja vida não vale a pena salvar' (p. $61 / 62)$.

Vi uma grande quantidade de papagaios e pensei que deveria apanhar um e criá-lo, para o domesticar e ensinar-lhe a falar-me. [...] trouxe-o para casa, mas foi muito antes de o conseguir fazer falar; contudo, por fim, consegui fazê-lo chamar-me pelo nome, duma forma perceptível (p. 110).

[...] deste tempo, muito foi gasto no terrível trabalho de fazer uma gaiola para o meu Poll, que começava a ser um simples doméstico e a ficar muito bem relacionado comigo (p. 112).

[...] enquanto estava a trabalhar me distraía falando com o meu papagaio e ensinando-o a falar, depressa conseguindo que ele conhecesse o seu nome e por fim o dissesse, bem explícito, POLL, que foi a primeira palavra que ouvi nesta ilha dita por alguém que não eu (p. 120).

“Oh, deserto feliz, não mais te verei!" (p. 138). 
Quando me aproximei, apareceu um cão, que, ao ver-me chegar, latiu e ladrou. Assim que o chamei, atirou-se à água, para vir ter comigo (p. 184).

\section{Imaginação}

Gastava horas inteiras imaginando, em cores vivas, como teria de agir se não tivesse trazido nada do barco [...] que teria vivido [...] como um simples selvagem [...] como uma fera (p. 130).

Imaginava-me agora como um dos antigos gigantes [...] viviam em cavernas e buracos nas rochas (p. 174).

[...] imaginava-me capaz de dirigir um, não, dois ou três selvagens, se os tivesse, de forma a torná-los inteiramente meus escravos [...] (p. 192).

\section{Experiência e Reflexão}

Numa palavra, a natureza e a experiência das coisas ditaram-me, depois de conveniente reflexão, que todas as coisas boas deste mundo só são boas para nós enquanto nos são úteis; e por mais que possamos acumular para dar outras, gozamo-las enquanto as pudermos utilizar, e não mais (p. 129).

Aprendi a olhar mais para o lado belo da minha situação do que para o pior e a tomar em consideração o que tinha, em vez daquilo de que necessitava [...] (p.129).

Todo o descontentamento acerca do que desejamos, parece-me a mim, advém da falta de gratidão pelo que temos (p. 130).

Reconhecer a bondade da Divina Providência em fazer o navio encalhar perto da costa (p.130).

[...] só posso recomendá-lo à reflexão daqueles que estão aptos, na sua miséria, a dizer: "Será alguma desgraça como a minha!"' (p.130).

Tinha outro pensamento que também me ajudava a confortar o espírito com esperanças; e era ao comparar a minha situação presente com aquilo que merecia e tinha [...] (p. 130).

Tão vazio estava do que era bom [...] nem uma vez tive a frase: "Graças a Deus", fosse no cérebro, fosse na boca; nem, nos maiores azares, tive sequer o pensamento de Lhe rezar, ou, ao menos, de dizer; "Deus, tende piedade de mim!"; não, nem sequer de mencionar o nome de Deus, a não ser para jurar por Ele e blasfemar (p. 131). 
Em resumo, se por um lado, a minha vida era de aflições, por outro, era uma vida cheia de mercês [...] nunca mais estive triste (p. 132).

Vida perversa e solitária começaram ambas no mesmo dia (30 de setembro) (p.132).

Oh!, quão ridículas decisões toma o homem quando cheio de medo! (p.156).

A fronteira da ansiedade é muito maior do que o próprio horror que tememos (p. 157).

[..] quão pouco ressentimento haveria na humanidade em qualquer condição de vida, se as pessoas comparassem a sua situação com a daqueles que estão pior, de forma a ficarem gratos [...] (p. 163).

Era certo que este povo não fazia isto como se fosse um crime, não era reprovado pelas suas consciências ou pelos seus dirigentes. Não sabiam que isto era um crime e não o faziam para ofender a justiça divina [...] comer carne humana era o mesmo para eles que para nós é comer carneiro (p. 167).

Concluí que estava errado e que estes seres não eram de modo algum assassinos, no sentido que eu tinha dado quando os condenei nos meus pensamentos (p. 167).

[...] sempre que tivesse pressentimentos para fazer ou não fazer determinada coisa ou para ir numa determinada direcção ou noutra, nunca deixar de obedecer a estes secretos ditames, embora não conhecesse outra razão para isso, para além de uma certa pressão ou sentimento no meu cérebro (p. 171).

Nunca é tarde para aprender (p. 171).

O mal que nós mais tememos é a porta da nossa salvação (p. 176).

Aquilo que é a salvação para um homem é a destruição para os outros (p. 180). 
Anexo I

\section{E-mail: Portal do Bibliotecário}



PORTAL DO BIBLIOTECÁRIO - E-mail oferece livros em pequenas doses para le... Página 1 de 1

E-mail oferece livros em pequenas doses para leitura móvel

Por: Administrator

Fonte: www.ofaj.com.br

28/05/08

Claudia Parsons

NOVA YORK (Reuters) - Nunca teve tempo de ler "Moby Dick" e quer algo mais respeitável para ler do que spam em seu Blackberry a caminho do trabalho?

Um novo site está oferecendo um serviço que envia clássicos da literatura na forma de pequenos trechos para computadores de mão ou por e-mail a cada manhã, antes dos usuários saírem para o trabalho, ou no horário que eles preferirem, gratuitamente.

Os emails do www.dailylit.com foram concebidos para oferecer tempo de leitura inferior a cinco minutos. "A Volta ao Mundo em 80 Dias", de Júlio Verne, está dividido em 82 partes, enquanto "Anna Karenina", de Leon Tolstoi, dividido em 430 partes, pode levar quase dois anos, em termos de dias de trabalho.

"Nossa audiência inclui pessoas como nós, que passam horas todos os dias enviando e recebendo emails, mas não encontram tempo para ler livros", disse Albert Wenger, cofundador do DailyLit.

A empresa começou a operar em maio, com uma lista de cerca de 370 títulos, em sua maioria clássicos. Wenger disse à Reuters que 50 mil pessoas assinaram o serviço, registrando mais de 75 mil títulos.

Já que os livros estão em domínio público, a empresa pode oferecê-los de graça, mas planeja se expandir e começar a cobrar uma taxa por títulos mais recentes, licenciados por grandes editoras, dentro de quatro ou cinco semanas. Os emails não contêm publicidade e o faturamento da empresa dependerá das taxas de assinatura, compartilhando a receita com as editoras.

"Nossa idéia é cobrar menos do que cinco dólares por título", disse Susan Danziger, mulher de Wenger e também co-fundadora do site, que trabalhava para a editora Random House, em entrevista telefônica à Reuters na terça-feira.

"As editoras gostam da idéia porque oferece um novo formato que elas ainda não exploraram", disse Danziger, acrescentando que estava negociando com editoras o lançamento de trechos de livros ainda inéditos, como forma de atrair o interesse de leitores.

A Berlitz, uma especialista em ensino de idiomas, é uma das cinco empresas que já fecharam acordo com o DailyLit, e em breve estará oferecendo aulas de idiomas estrangeiros em porções de cinco minutos.

(Divulgado por Elizandra Martins - Enviado para Infohome em 23/05/2007)

http://www.portalbibliotecario.com.br/index2.php?option=com_content\&task=view\&id.... 2/7/2009 